\title{
A Methodological Framework for Life Cycle Sustainability Assessment of Construction Projects Incorporating TBL and Decoupling Principles
}

\author{
Shivam Srivastava ${ }^{1, *}$, Usha Iyer Raniga ${ }^{2,3, * \mathbb{D}}$ and Sudhir Misra ${ }^{1, *}$ \\ 1 Department of Civil Engineering, Indian Institute of Technology Kanpur, Kanpur 208016, India \\ 2 School of Property, Construction and Project Management, RMIT University, Melbourne, VIC 3000, Australia \\ 3 Sustainable Buildings and Construction Programme, Co-Lead United Nations One Planet Network, \\ 75015 Paris, France \\ * Correspondence: shvmsri@iitk.ac.in (S.S.); usha.iyer-raniga@rmit.edu.au (U.I.R.); sud@iitk.ac.in (S.M.); \\ Tel.: +91-512-259-7346 (S.S.); Fax: +91-512-259-6296 (S.S.)
}

check for updates

Citation: Srivastava, S.; Raniga, U.I.; Misra, S. A Methodological Framework for Life Cycle Sustainability Assessment of Construction Projects Incorporating TBL and Decoupling Principles. Sustainability 2022, 14, 197. https:// doi.org/10.3390/su14010197

Academic Editor: Antonio Caggiano

Received: 12 August 2021

Accepted: 3 November 2021

Published: 25 December 2021

Publisher's Note: MDPI stays neutral with regard to jurisdictional claims in published maps and institutional affiliations.

Copyright: (c) 2021 by the authors. Licensee MDPI, Basel, Switzerland. This article is an open access article distributed under the terms and conditions of the Creative Commons Attribution (CC BY) license (https:// creativecommons.org/licenses/by/ $4.0 /)$.

\begin{abstract}
The triple bottom line (TBL) principle encompasses the idea of continued economic and social well-being with minimal or reduced environmental pressure. However, in construction projects, the integration of social, economic, and environmental dimensions from the TBL perspective remains challenging. Green building rating tools/schemes, such as Green Rating for Integrated Habitat Assessment (GRIHA), Leadership in Energy and Environment Design (LEED), Building Research Establishment Environment Assessment (BREEAM), and their criteria, which serve as a yardstick in ensuring sustainability based practices and outcomes, are also left wanting. These green building rating tools/schemes not only fail to comprehensively evaluate the three dimensions (social, economic, and environment) and interaction therewith, but also lack in capturing a life cycle approach towards sustainability. Therefore, this study intends to address the aforementioned challenges. The first part of this study presents the concept of sustainable construction as a system of well-being decoupling and impact decoupling. Findings in the first part of this study provide a rationale for developing a methodological framework that not only encapsulates a TBL based life cycle approach to sustainability assessment in construction, but also evaluates interactions among social and economic well-being, and environmental pressure. In methodological framework development, two decoupling indices were developed, namely, the phase well-being decoupling index $\left(\mathrm{PWBDI}_{\mathrm{K}}\right)$ and phase impact decoupling index $\left(\mathrm{PIDI}_{\mathrm{K}}\right)$. $\mathrm{PWBDI}_{\mathrm{K}}$ and $\mathrm{PIDI}_{\mathrm{K}}$ support the evaluation of interdependence among social and economic well-being, and the environmental pressure associated with construction projects in different life cycle phases. The calculation underpinning the proposed framework was illustrated using three hypothetical cases by adopting criteria from GRIHA Precertification and GRIHA v.2019 schemes. The results of these cases depict how the interactions among different dimensions (social, economic, and environment) vary as they move from one phase to another phase in a life cycle. The methodological framework developed in this study can be tailored to suit the sustainability assessment requirements for different phases and typologies of construction in the future.
\end{abstract}

Keywords: triple bottom line (TBL); green building rating tools; sustainability assessment; sustainable construction; life cycle assessment; decoupling

\section{Introduction}

Sustainability considerations in the building and construction (B\&C) sector are becoming more important due to increasing international pressure to address the UN's Sustainable Development Goals (SDGs), a universal framework for sustainable development that revolves around people, planet, and prosperity [1]. The building and construction sector impacts all three dimensions of sustainability; namely, social, environmental, and economic, also known as the triple bottom line (TBL). Social impact by creating spaces to 
live and work in, economic impact by contributing to gross domestic product (GDP) and creating jobs, and environmental impact due to the usage of resources and raw materials and the generation of construction and demolition (C\&D) waste during the processes of construction [2-4]. C\&D is the industry term for end of life determination of building and construction materials, although increasingly from a circular economy perspective, this term may considered as deconstruction instead. Buildings/constructed facilities may last 80-100 years or more, and they need to be maintained throughout their life cycle. The operation, maintenance, and decommissioning phases of a constructed facility also have social impact, through the wellbeing of spaces and improvement in productivity, etc.; economic impact through procurement costs, operational costs, job opportunities, etc.; and environmental impact through the use of energy, water, waste generation, etc. However, the pace of the $B \& C$ sector in adopting life cycle cum TBL based sustainability practices is slow [5].

In delivering TBL based sustainability outcomes, the implementation of green/sustainable building and construction assessment tools/schemes may be helpful [3,6]. Green Rating for Integrated Habitat Assessment (GRIHA-India), Leadership in Energy and Environment Design-Indian Green Building Council (LEED-IGBC-India), Green Star-Australia, Building and Construction Authority Green Mark (BCA Green Mark-Singapore), Deutsche Gesellschaft für Nachhaltiges Bauen (DGNB-Germany), Comprehensive Assessment System for Built Environment Efficiency (CASBEE-Japan), Building Research Establishment Environment Assessment (BREEAM-UK), Green Globes-Canada, Green Building Index (GBI-Malaysia), Global Sustainability Assessment System (GSAS-Gulf countries), and others are some of the popular assessment tools/schemes in different regions and countries of the world. These rating tools/schemes serve as a reference guide to assess the building/constructed facility's sustainability performance. The tools have been developed so as to include a set of parameters that pertain to the design, construction, operation, and maintenance phases of buildings/constructed facilities [7]. However, to ensure continuous delivery of sustainability outcomes, current sustainability assessment tools/schemes need to continuously improve to overcome their various limitations, such as lack of life cycle assessment considerations, a holistic approach, performance orientation, effective communications, continuity, participation, a specific vision, adequate scope, a clear framework and indicators, and others [8-13]. Most of the current assessment tools/schemes award certification to buildings/construction based on a single compiled score, in which the environmental aspect of sustainability dominates the social and economic aspects of sustainability. Within these certification tools / schemes, the life cycle approach should be consistently considered, rather than individual measurements for evaluating the overall performance of construction projects [13]. These assessment systems should be transparent, tailor made, and flexible enough for assessing the sustainability requirements of preconstruction, construction, operation and maintenance, and the decommissioning/deconstruction phases of construction.

Growing acceptance of the life cycle based sustainability approach and its evaluation requires comprehending the relationships and interactions of different dimensions of sustainability by tactically bringing them together. Decoupling analysis is one such tool, which evaluates the quality of economic growth by measuring the coupling between economic growth, and environmental impact and resource use. Decoupling evaluation is at the core of the sustainability framework [14]. Current sustainability assessment frameworks for buildings/construction lacks decoupling evaluation. The majority of previous studies for evaluating decoupling in the B\&C sector were at an aggregated industrial level, and evaluated decoupling between two dimensions of sustainability only, i.e., between economic and environment [15-17].

At present, there is no sustainability assessment rating tool/scheme for buildings/construction that explicitly focuses on measuring sustainability from the TBL perspective incorporating decoupling evaluation. Hence, a conceptual sustainability assessment framework needs to be developed, not just for the rating of the constructed facility, but also because of 
the life cycle of a building. A framework that focuses on a life cycle cum TBL based sustainability approach and, at the same time, ensuring the transition from linear (less sustainable) to circular (more sustainable) systems is critical. Therefore, this research focuses on developing TBL based sustainability assessment framework cutting across different life cycle phases, simultaneously evaluating the transition of linear systems to circular systems using scores obtained from TBL based sustainability assessment at each phase of construction.

The objectives of the current study are as follows:

1. To identify different TBL based sustainability, i.e., social, economic, and environmental, assessment parameters and indicators for the different life cycle phases of a construction.

2. To propose a methodological framework and classification system by integrating TBL based life cycle sustainability parameters and decoupling indices.

Following this introduction, Section 2 critical reviews the current literature on the interaction among different aspects of sustainability, current sustainability assessment frameworks and presents a comparison of ten rating tools from the TBL perspective. In Section 3, the research method is presented. This section offers analysis of the extracted TBL based life cycle sustainability assessment parameters and presents the methodological framework for calculating TBL scores for life cycle phases and decoupling indices. Section 4 focuses on the hypothetical cases, taking GRIHA criteria to illustrate the calculation procedure of decoupling indices developed in the framework. Section 5 provides the conclusion related to this research.

\section{Building and Construction Sustainability}

\subsection{Rethinking Sustainability as a System of Well-Being Decoupling and Impact Decoupling}

Construction is critical to the sustainable development framework, as it affects three dimensions of sustainability: social well-being, economic well-being, and environmental pressure [18-20]. Construction has traditionally operated as a "take, make, waste" process, taking raw material from nature, using it in construction and then either abandoning the facility after use or dumping the debris into a landfill. This approach to construction is known as the linear approach to construction. Critical evaluation of current construction processes reveals that they are high on the consumption of resources and pollution creation [21,22]. The net result of this is the increasing scarcity of construction materials and reduction in available natural resources at an alarming rate. Growing concern for the environment, especially in the last few decades, has resulted in several agreements and efforts to define a framework for sustainable development, with an emphasis on concepts such as reduce, recycle, and reuse; more use of green buildings; renewable energy; zero waste; and other such related concepts.

Construction, especially in developing countries, is modelled on a linear approach [23]. The linear approach to construction is characterized by an increase in demand for extracting virgin materials for production and the subsequent construction, operation and maintenance of a project. However, even during/after the construction, operation and maintenance of a project, it continues to impact other aspects of sustainability, i.e., the economic and social. On the economic side, focus is usually on the increase in production profits. With increased production profits, further investment in the economy leads to better job opportunities. In addition, with better job opportunities and economic activities, the socioeconomic gap decreases.

On the contrary, this linear approach further intensifies the extraction of virgin materials and, as a result, sustaining economic and social well-being in the long run is not certain. In a linear approach, social well-being and its improvement are largely dependent on the use of resources from nature and, with an ever increasing population, the use of resources is bound to increase and, as a result, environmental pressure will increase. Economic wellbeing and growth are also associated with the ever increasing use of resources, resulting 
in environmental degradation. If continued in the same way, these impacts will lead to disruptions in ecosystem services that are vital to social well-being [14].

To ensure sustainability in the longer run, the vision should not be only aimed at minimizing resource use/resource optimization as this may result in slowing down economic growth [24]. The new systems that enable resource optimization, reduce environmental impacts, and provide alternative economic returns and the social well-being of stakeholders associated with construction, need to be developed [25].

Seeing the nature of the resource intensive construction industry, developing tools for estimating well-being decoupling and impact decoupling and incorporating them in sustainable assessment has become critical to realize the true picture of sustainability (Figure 1). In other words, construction needs assessment models to ensure the decoupling of social and economic well-being from environmental pressures created in different phases of a construction.

Conceptual planning and Feasibility study

$\rightarrow$ Design \& Engineering $\rightarrow$ Construction $\rightarrow$

Operation \& Maintenance $\rightarrow$ End-of-Life

Life cycle phases of a construction

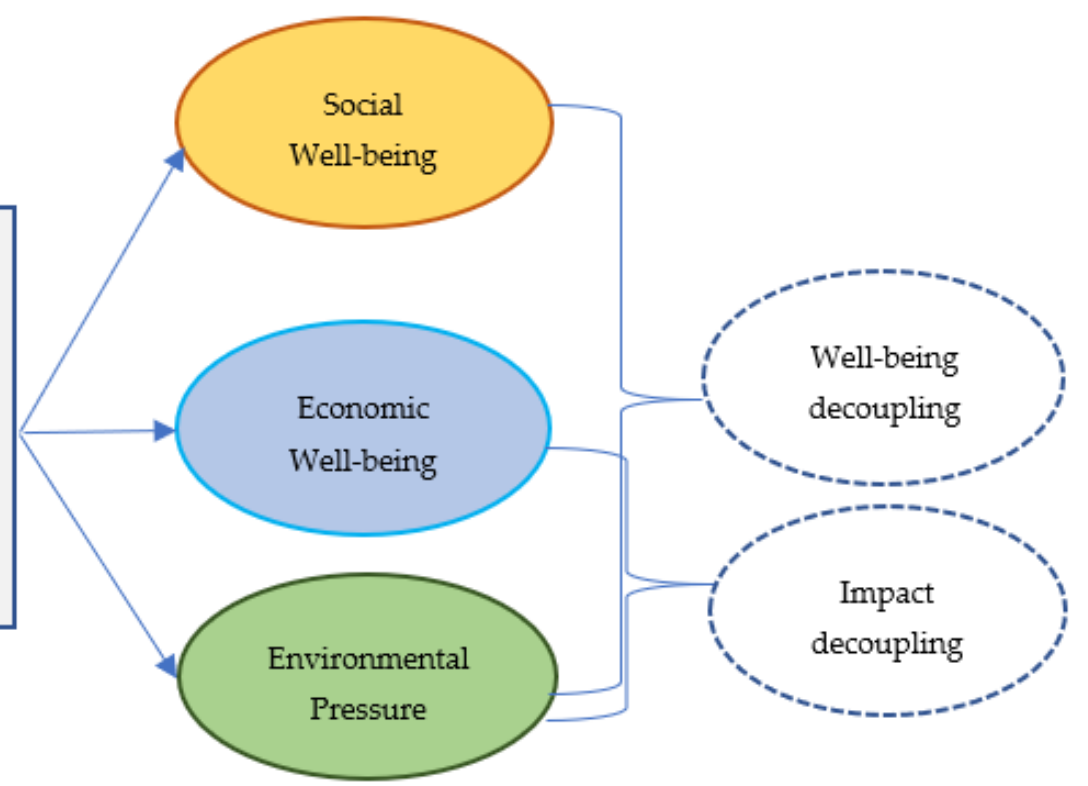

Figure 1. Schematic diagram representing TBL cum decoupling model of sustainability in construction.

\subsection{Current Sustainability Assessment Frameworks in Construction}

To assess the extent of sustainability compliance, a framework encapsulating sustainability assessment principles and sustainability procedures is required. According to Sala et al., (2015) [8], a framework for sustainability assessment should be based on certain principles, such as: guiding vision (progress towards the goal of delivering well-being should be within planetary limits and ensured for current as well as future generations), essential considerations (incorporating social, economic and environment components and their interactions), adequate scope (progress towards sustainable development should adopt certain timeline, to address both short and long term effects, and it should also capture local as well as global effects), framework and indicators (based on a certain conceptual framework that is to be linked with identified core indicators and reliable data), transparency (the transparency of data and data sources for indicators should be considered), effective communication (clearly communicating with a wide audience and the proper dissemination of results), continuity and capacity (should be continuously monitored and scored), and broad participation (it should encourage legitimacy and relevance by the way of interaction among stakeholders right from the initial stages of the project).

The construction industry, too, has a long history of developing and using such sustainability assessment frameworks [26,27]. Green building councils of different countries are actively involved in developing such frameworks for sustainability assessment schemes. Typically, assessment schemes have been devised using a yardstick for delivering 
sustainability outcomes through constructed facilities. GRIHA (India), LEED-IGBC (India), Green Star (Australia), BCA Green Mark (Singapore), DGNB (Germany), CASBEE (Japan), BREEAM (UK), Green Globes (Canada), GBI (Malaysia), GSAS (Gulf countries), and others are some of the prevalent assessment tools/schemes. As already mentioned, green rating tools/schemes include a set of parameters and indicators to assess the level of sustainability [7]. Illankoon et al. (2017) [28], after reviewing and comparing eight international green building tools, established seven key criteria in these rating tools as follows: site, energy, water, indoor environment quality, materials, waste and pollution, and management. Other than these key criteria, criteria such as triple bottom line (TBL) reporting, education and awareness, the economic aspects of various costs, sustainable design and planning, and stakeholder engagement can be used to develop new rating tools in the future, as these are missing from the rating tools but illustrated in literature [28].

\subsubsection{Critique of Current Sustainability Assessment Frameworks in Construction}

Often, the terms green and sustainable construction are used synonymously, but they do have slightly different meanings. As per the US EPA, green building is also referred to as green construction, a structure with an application of processes that are environmentally friendly and resource efficient throughout their life cycle, i.e., during planning, construction, operation, maintenance, renovation, and end of life phases. However, a sustainable building or construction is not only about environmental protection and promoting resource optimization, but should also encompass social well-being factors-such as: (1) security, safety, satisfaction, comfort, and human contributions such as skills, health, knowledge, and motivation [29,30]; (2) people's social-cultural spiritual needs [31]; and (3) education and skill development, equality, health and safety, community engagement and benefits [32] —and economic sustainability parameters, such as: (1) monetary gains to the stakeholders from the project [33]; (2) growth, efficiency and stability [34]; and (3) employment and economic opportunities [35]. A sustainability framework in construction should be based on the fact that construction activities should be socially, economically, and environmentally safe [28].

Critical evaluation of ten rating tools/schemes reveals that most of them deliver a single rating to construction projects after evaluating them against a predetermined set of sustainability parameters that are mostly dominated by environmental parameters. Most of these rating tools/schemes are biased towards evaluating environmental sustainability, whereas economic and social aspects are partially neglected [28]. Though most of the rating tools / schemes consider social dimensions by allocating $25 \%$ of the credit points on average, economic sustainability is rarely evaluated. The DGNB (Germany) rating system gives substantial weightage to economic sustainability by allocating $30 \%$ of the credit points, in comparison to other tools (Table 1).

Table 1. Weights of TBL (social, economic, and environment) credits in different rating tools/schemes.

\begin{tabular}{cccc}
\hline Building Assessment Tools & Social & Economic & Environment \\
\hline GRIHA (India) & 24 & 5 & 71 \\
LEED-IGBC (India) & 18 & - & 82 \\
Green Star (Australia) & 31 & - & 69 \\
Green Mark (Singapore) & 18.8 & - & 81.2 \\
DGNB (Germany) & 30 & 30 & 40 \\
* CASBEE (Japan) & 28.8 & 6.2 & 65 \\
BREEAM (UK) & 26 & 12 & 62 \\
Green Globes (Canada) & 22 & 1 & 78 \\
GBI (Malaysia) & 28 & 3 & 71 \\
GSAS (Gulf) & 28 & - & 69
\end{tabular}

* Refer to Appendix A for methodology and detailed division of credits from TBL considerations in different rating tools/schemes. * CASBEE (Japan): It does not allocate any credit points; it calculates built environment efficiency (BEE) as the ratio of environmental quality of a building to an environmental load of a building. 
The rationale for focusing more on environmental sustainability is that once environmental sustainability criteria are satisfied then social and economic aspects will be taken care of [36]. Moreover, some of the researchers claim that most rating tools/schemes fail to capture a TBL based perspective on sustainability [10]. The lack of consideration of social and economic dimensions in building performance during its life cycle leads to a deviation from the true meaning of sustainability. Most of the assessment tools and respective criteria (credits) are concerned with the design, construction, and operation and maintenance phases of a project; conception and demolition/decommissioning are not explicitly considered [37].

Life cycle sustainability assessment (LCSA) is defined as the evaluation of environmental, social, and economic negative impacts and benefits that occur through decisionmaking processes, towards more sustainable projects/products throughout the life cycle of projects/products [38] (Equation (1)).

$$
L C S A=f(S o c-L C A+E c o-L C A+E n v-L C A)
$$

where,

Soc-LCA = $\mathrm{f}$ (social assessment parameters, conceptual planning and feasibility study, design and engineering, construction, operation and maintenance, and end-of-life);

$E c o-L C A=\mathrm{f}$ (economic assessment parameters, conceptual planning and feasibility study, design and engineering, construction, operation and maintenance, and end-of-life); and

$E n v-L C A=\mathrm{f}$ (environment assessment parameters, conceptual planning and feasibility study, design and engineering, construction, operation and maintenance, and end-of-life)

Life cycle sustainability assessment/management is missing from such tools/schemes. In a review paper, Wulf et al. (2019) [39] found that, in recent years, with respect to LCSA, the focus has been more on case studies and less on developing methodological frameworks. Sala et al. (2013) [40], in their study, advocate the development of a methodology that adopts a holistic approach and has the capacity to address general or complex system theory. Critical topics that need to be addressed in developing an LCSA based methodological framework should include the development of quantitative and practical indicators for Soc-LCA, approaches to assess the scenarios from a life cycle perspective, standardizing methods to include uncertainties, synergies, and tradeoffs between different dimensions of sustainability $[41,42]$. Although the literature shows TBL perspectives have been gradually adopted, in-depth investigation of environmental, economic, and social holistically is still missing [4].

Any kind of sustainable assessment and management of construction requires close coordination and interactions among internal and external stakeholders that are associated with the construction project life cycle phases, otherwise, the assessment becomes too theoretical [43-45].

Another aspect that is critical for LCSA is decoupling analysis. "Decoupling" as a term was first advanced by the OECD in 2001; it highlights the concept of continued socio-economic growth with diminishing environmental impacts. Decoupling and its evaluation, which is at the core of the sustainability framework [14], is missing from such rating tools/schemes, though the underlining principles of sustainability assessment overlap with decoupling. Central to the UN SDGs/Agenda 2030, decoupling serves as a foundation for materializing the overarching framework of sustainable development; without decoupling the UN SDGs will not be achievable [46].

Current research challenging existing LCSA frameworks call for (1) adopting a holistic approach towards understanding the dynamic interactions between different dimensions of sustainability, (2) shifting from multidisciplinary to transdisciplinary approaches, (3) capability of moving forward through visions and goals, (4) continuous social learning for the stakeholders, and (5) probabilistic approach for dealing with uncertainties [8].

Based on the above critiques, at present, the current rating tools/schemes for supporting sustainability outcomes are left wanting, as they do not deal with all the aspects of 
TBL and interactions thereof. Moreover, real world, i.e., industry practices, have also not presented as a way forward in supporting TBL based sustainability outcomes. Hence, the current study puts forward a methodological LCSA framework that focuses on TBL based sustainability outcomes and, at the same time, ensures the transition from less sustainable (coupled) systems to more sustainable (decoupled) systems.

\section{Research Method}

This research is designed in three parts, as shown in Figure 2. In part 1, the study commences with a review of the current green/sustainability rating tools/schemes from the TBL perspective by examining each of the assessment parameters of these rating tools/schemes and classifying them under environment, social or economic categories. It presents a critique of current sustainability assessment frameworks in construction and then establishes the need for the present study.

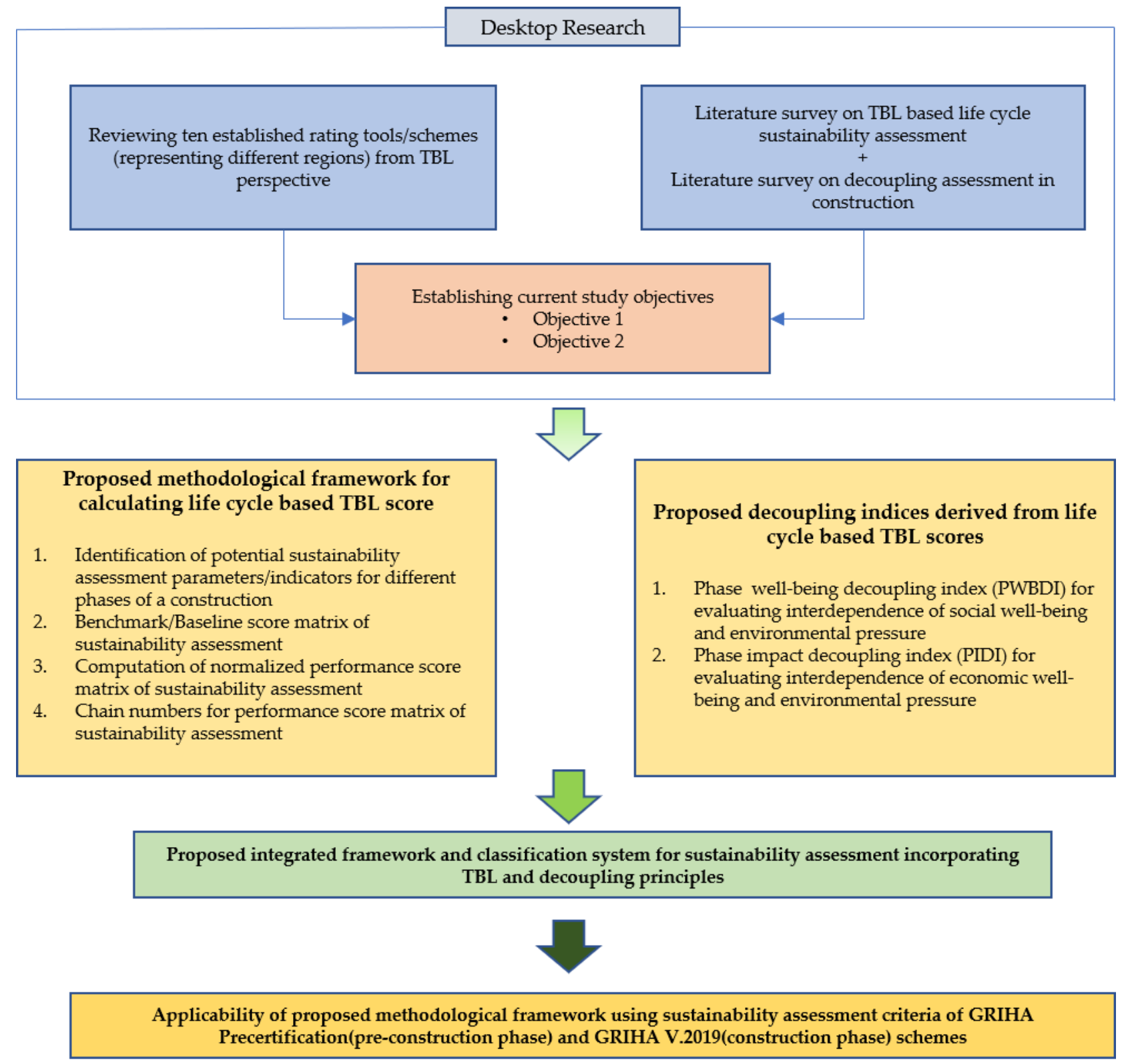

Figure 2. Research methodology flowchart.

In part 2, the extraction, integration, and identification of potential TBL based sustainability assessment parameters from different sources, cutting across different life cycle 
phases (conceptual planning and feasibility, design and engineering, construction, operation and maintenance, end of life) of a construction project, are presented. In addition, a new methodological framework for the LCSA of construction, incorporating TBL and decoupling principles, is presented in this part. This part also presents the key steps involved in computing TBL scores and decoupling indices for different phases, and a classification system for mapping construction projects using computed TBL scores and decoupling indices.

In part 3, the application of the proposed methodological framework using the sustainability assessment criteria of GRIHA Precertification and GRIHA v.2019 schemes are presented, and calculations are shown for computing decoupling indices (well-being and impact decoupling indices) using three hypothetical cases, followed by conclusions and limitations of this research.

\subsection{Extraction of Life Cycle Based TBL Sustainability Assessment Parameters}

TBL based sustainability parameters and their potential indicators were extracted from previous works. Sustainability parameters and their indicators are prerequisites for any sustainability assessment, as they are critical for setting/translating into sustainability targets [8] (Sala et al., 2015). Based on this argument, the sustainability assessment parameters for different construction phases, along with their description and potential indicators, were identified through a sequential literature review (SLR). A similar approach was used by Stanitsas et al. (2020) [47], to identify the sustainability indicators for the management of construction projects. These identified parameters are knowingly put at a higher level with fewer details about their indicators, as there can be numerous potential indicators under each of the sustainability assessment parameters. The selection of indicators depends on various factors based on regional context, and may not be globally accepted. Tables $2-4$ present the holistic view of TBL based sustainability assessment parameters that are relevant to different phases of a construction project. This set of identified parameters form the rationale for developing an integrated framework and classification system for sustainable construction, incorporating TBL and decoupling principles.

Table 2. Pool of relevant social based sustainability assessment parameters for different phases of construction.

\begin{tabular}{|c|c|c|c|}
\hline \multicolumn{4}{|c|}{ Social Sustainability Parameters (Phase 1. Conceptual Planning and Feasibility Study) } \\
\hline Parameters & Description & Indicators & References \\
\hline $\begin{array}{l}\text { Stakeholders' consultation } \\
\text { and engagement }\end{array}$ & $\begin{array}{l}\text { Consultation and engagement with } \\
\text { stakeholders/affected communities } \\
\text { to identify and monitor their } \\
\text { concerns and opportunities in } \\
\text { different phases of construction }\end{array}$ & $\begin{array}{l}\text { Consultation/engagement report } \\
\text { based on parameters such as: } \\
\text { expectations, project constraints, } \\
\text { partnership, safety, employment, } \\
\text { training, accessibility, and others * }\end{array}$ & [48-58] \\
\hline $\begin{array}{l}\text { Health and safety } \\
\text { considerations }\end{array}$ & $\begin{array}{c}\text { Planning for health and safety } \\
\text { issues related to workers (including } \\
\text { female workers), users, and other } \\
\text { stakeholders }\end{array}$ & $\begin{array}{l}\text { Considerations of guidelines } \\
\text { related to health and safety of the } \\
\text { stakeholders, which can be } \\
\text { documented in the form of Health } \\
\text { Impact Assessment (HIA)* }\end{array}$ & {$[52,53,57,59-61]$} \\
\hline Ethical considerations & $\begin{array}{l}\text { Planning to promote and ensure } \\
\text { professional ethics, avoiding ethical } \\
\text { dilemmas, dealing with conflicts of } \\
\text { interest, and others }\end{array}$ & $\begin{array}{c}\text { Adopting a framework for } \\
\text { monitoring and ensuring } \\
\text { compliance to ethical practices * }\end{array}$ & [62-67] \\
\hline
\end{tabular}


Table 2. Cont.

\begin{tabular}{|c|c|c|c|}
\hline \multicolumn{4}{|c|}{ Social Sustainability Parameters (Phase 2. Design and Engineering) } \\
\hline Parameters & Description & Indicators & References \\
\hline $\begin{array}{c}\text { Decent work and economic } \\
\text { growth }\end{array}$ & $\begin{array}{l}\text { Incorporate policies for creating job } \\
\text { opportunities in neighborhood } \\
\text { communities, maintaining social } \\
\text { and demographic equity in the } \\
\text { design team, construction workers, } \\
\text { and others involved in different life } \\
\text { cycle phases }\end{array}$ & $\begin{array}{l}\text { Adopting/implementing } \\
\text { framework for assessing the trends } \\
\text { in the stocks of natural resources, } \\
\text { emissions, and discharges in the } \\
\text { environment resulting from } \\
\text { economic activities; accounting of } \\
\text { environmental preservation cost } \\
\text { and conservation cost }\end{array}$ & {$[1,68,69]$} \\
\hline $\begin{array}{l}\text { Health, well-being, and the } \\
\text { environment }\end{array}$ & $\begin{array}{l}\text { Design for better health, } \\
\text { outdoor/indoor environments that } \\
\text { promotes better lifestyle practices, } \\
\text { nutrition, social connectivity, } \\
\text { minimized infectious disease } \\
\text { transmission, and others }\end{array}$ & $\begin{array}{l}\text { Adopting design considerations } \\
\text { such as: universal accessibility and } \\
\text { sustainable transportation, } \\
\text { resilient buildings and } \\
\text { infrastructure, } \\
\text { high quality public and green } \\
\text { spaces, good mental health, and } \\
\text { others * }\end{array}$ & [68-70] \\
\hline $\begin{array}{l}\text { Design with socioeconomic } \\
\text { consideration }\end{array}$ & $\begin{array}{l}\text { Design for promoting culture of } \\
\text { occupational health (physical and } \\
\text { mental), safety, social inclusion of } \\
\text { workers, and include labor } \\
\text { provisions in tendering process and } \\
\text { supplier contracts }\end{array}$ & $\begin{array}{l}\text { Adopting design considerations } \\
\text { such as: design for safety and } \\
\text { sanitation for construction workers, } \\
\text { design for dedicated facilities for } \\
\text { service staff, design for the positive } \\
\text { social impact, which include } \\
\text { provisions for promoting gender } \\
\text { equality, protecting labour rights, } \\
\text { and others }\end{array}$ & {$[68,71]$} \\
\hline $\begin{array}{l}\text { Long term value to the society } \\
\text { and enhancing local quality of } \\
\text { life }\end{array}$ & $\begin{array}{l}\text { Designs considering physical and } \\
\text { environmental impacts on the local } \\
\text { area, taking community input for } \\
\text { improving community's health }\end{array}$ & $\begin{array}{l}\text { Adopting a framework for } \\
\text { evaluating social value to the } \\
\text { society }\end{array}$ & {$[68,69]$} \\
\hline $\begin{array}{l}\text { Prioritizing occupant's } \\
\text { comfort }\end{array}$ & $\begin{array}{c}\text { Designs with considerations for } \\
\text { environment that is comfortable to } \\
\text { occupant }\end{array}$ & $\begin{array}{l}\text { Adopting guidelines of ASHRAE } \\
\text { standards for the design of high } \\
\text { performance green buildings, } \\
\text { which include: } \\
\text { thermal comfort, natural and } \\
\text { energy efficient lighting, acoustic } \\
\text { comfort, olafactory, ergonomics, } \\
\text { and visual comforts in designs }\end{array}$ & {$[68,72]$} \\
\hline
\end{tabular}

\begin{tabular}{|c|c|c|c|}
\hline \multicolumn{4}{|c|}{ Social Sustainability Parameters (Phase 3. Construction) } \\
\hline Parameters & Description & Indicators & References \\
\hline $\begin{array}{c}\text { Socioeconomic strategies for } \\
\text { workers }\end{array}$ & $\begin{array}{c}\text { Avoidance of unsafe } \\
\text { acts/conditions, promoting gender } \\
\text { equality, labor rights, habitable } \\
\text { living conditions, grievance } \\
\text { redressal mechanism, sustainability } \\
\text { awareness, training, skills, and } \\
\text { others for workers during } \\
\text { construction }\end{array}$ & $\begin{array}{c}\text { Adopting a framework for defining } \\
\text { and delivering socioeconomic } \\
\text { benefits to the construction } \\
\text { workforce * }\end{array}$ & {$[68,73-77]$} \\
\hline $\begin{array}{l}\text { Long term value to the society } \\
\text { and local quality of life }\end{array}$ & $\begin{array}{l}\text { Environmental practices at } \\
\text { construction sites }\end{array}$ & $\begin{array}{l}\text { Adopting guidelines for mitigation } \\
\text { of air pollution, noise pollution, } \\
\text { traffic, congestion, waste, and other } \\
\text { pollution created on site and in } \\
\text { surrounding areas }\end{array}$ & {$[68,78,79]$} \\
\hline
\end{tabular}


Table 2. Cont.

\begin{tabular}{|c|c|c|c|}
\hline \multicolumn{4}{|c|}{ Social Sustainability Parameters (Phase 4. Operation and Maintenance) } \\
\hline Parameters & Description & Indicators & References \\
\hline $\begin{array}{l}\text { Prioritizing occupant's } \\
\text { comfort }\end{array}$ & $\begin{array}{l}\text { Creating an environment that } \\
\text { enhances occupant's comfort } \\
\text { during operational phase }\end{array}$ & $\begin{array}{l}\text { Adopting a framework for } \\
\text { measuring and enhancing } \\
\text { occupant's comfort* }\end{array}$ & {$[68,80-83]$} \\
\hline $\begin{array}{l}\text { Operations for protecting and } \\
\text { improving health }\end{array}$ & $\begin{array}{l}\text { Support and enhancement of } \\
\text { physical/mental health, } \\
\text { minimization of infectious disease } \\
\text { transmission, accessibility to public } \\
\text { transport, space for physical } \\
\text { activities, healthy food options, } \\
\text { access to clean water, and others }\end{array}$ & $\begin{array}{l}\text { Conducting postoccupancy } \\
\text { evaluation survey results and } \\
\text { adopting mitigation measures for } \\
\text { infectious disease and improving } \\
\text { health in a built environment }\end{array}$ & {$[68,84-86]$} \\
\hline $\begin{array}{l}\text { Socioeconomic strategies } \\
\text { during the operational phase }\end{array}$ & $\begin{array}{l}\text { Creating wider social and economic } \\
\text { benefits to relevant stakeholders }\end{array}$ & $\begin{array}{l}\text { Adopting a framework for } \\
\text { assessing and promoting diversity, } \\
\text { equity, and inclusions among } \\
\text { stakeholders }\end{array}$ & {$[68,87,88]$} \\
\hline \multicolumn{4}{|c|}{ Social Sustainability Parameters (Phase 5. End of life) } \\
\hline Parameters & Description & Indicators & References \\
\hline $\begin{array}{l}\text { Effective project } \\
\text { communication }\end{array}$ & $\begin{array}{l}\text { Disclosure/digital dissemination of } \\
\text { information to the public about } \\
\text { dismantling process, and other } \\
\text { related issues }\end{array}$ & $\begin{array}{l}\text { Evaluate the level of } \\
\text { communication among } \\
\text { stakeholders * }\end{array}$ & {$[89,90]$} \\
\hline Security & $\begin{array}{l}\text { Work and safety plan for the } \\
\text { contaminated/noncontaminated } \\
\text { area, and other related issues }\end{array}$ & $\begin{array}{l}\text { Considerations of guidelines } \\
\text { related to health, safety, and } \\
\text { security of the stakeholders * }\end{array}$ & [90-92] \\
\hline
\end{tabular}

$1 *$ For further explanation refer to Appendix B.

Table 3. Pool of relevant economic based sustainability assessment parameters for different phases of construction.

\section{Economic Sustainability Parameters (Phase 1. Conceptual Planning and Feasibility Study)}

Parameters Description Indicators References

\section{Adopting/implementing}

Integrating economic and

System of environmental-economic accounting environmental data for analysing the interrelationship between economy and environmental stock changes

Estimating the return on

Financial and economic feasibility

investment, creditworthiness, viability, and cash flow during the entire life cycle of a project

Concerning different processes and planning for controlling the cost of resources and other costs of the construction

Cost management plan

Human resource planning
Concerning the capacities and capabilities of an individual worker in contributing towards sustainability framework for assessing the trends in the stocks of natural resources, emissions, and discharges in the environment resulting from economic activities; accounting of environmental preservation cost and conservation cost

Financial and economic feasibility assessment report of construction projects

Adopting framework to avoid time and cost overrun during different phases of a construction

Adopting a framework for human resource management (HRM), focusing on aspects such as defined task domain of an employee, recruitment, remuneration, working conditions, training of the workforce, etc. 
Table 3. Cont.

Economic Sustainability Parameters (Phase 1. Conceptual Planning and Feasibility Study)

Parameters Description Indicators

References

Strategies for collaborative practices, ensuring selection of order winners for improved business case

Supply chain collaboration

Targeted incentives

Strategies for incentivizing to increase worker's motivation and improving work productivity

Ability to pay and affordability
Cost bearing ability of users during construction, operation, and maintenance of a project
Measuring level of collaboration in

the supply chain, i.e., collaboration index

[105-110]

Adopting a framework for targeted incentive schemes during different project phases

Adopting framework to evaluate/facilitate the cost reduction of the constructed facility

[111-113]

Economic Sustainability Parameters (Phase 2. Design and Engineering)

\section{Parameters}

Description

Design with considerations and promoting resource efficiency by

Design for quality of service adopting principle shift from linearity to circularity in construction

Indicators

References

Indicators

(n)

Adopting design principles such as: functionality and usability, durability and reliability, design for maintenance consideration, flexibility and adaptability for future changes, design for assembly and disassembly (DfD), design for extended life, and reuse/remanufacturing/recycling, specifying reclaimed/recycled materials, and others

Adopting framework that assists in
different design/specifications alternatives with different cash flows over life cycle of construction project
$[70,116,117]$ cycle of the construction project, which includes acquisition cost, facility management (operational) cost, and disposal cost
Life cycle costing for alternative designs

\section{Economic Sustainability Parameters (Phase 3. Construction)}

Parameters
$\begin{gathered}\text { Cost, quality, and schedule } \\ \text { management }\end{gathered}$

Innovation and productivity

$$
\text { Description }
$$

Ensure reduction in the cost of poor quality work and avoid time-cost overruns in building/construction projects

Enhance growth through innovation and productivity in building/construction projects

Indicators

Adopting a framework for performance management in construction projects
References

[118-122]

Adopting a framework for promoting innovation and productivity in construction processes

Economic Sustainability Parameters (Phase 4. Operation and Maintenance)

\begin{tabular}{cccc}
\hline Parameters & Description & Indicators & References \\
\hline Operational costs & & $\begin{array}{c}\text { Adopting models for predicting life } \\
\text { cycle costing that includes the cost for } \\
\text { periodic inspections, facility's } \\
\text { operational cost, preventive } \\
\text { maintenance cost of built } \\
\text { nvironment }\end{array}$ & $\begin{array}{c}\text { maintenance cost, replacement and } \\
\text { repairs cost, and reactive } \\
\text { maintenance cost }\end{array}$ \\
& [126-128] \\
\hline
\end{tabular}

\section{Adopting a framework for built asset} management with indicators such as responsible building operations, maintenance of built assets, managing environmental risks,

Risk management and long Ensure resilience of the built assets term asset value
Ensure resilience of the built assets
by managing risks proactively
analysing potential risks, and
preparation for climate action


Table 3. Cont.

\begin{tabular}{|c|c|c|c|}
\hline \multicolumn{4}{|c|}{ Economic Sustainability Parameters (Phase 4. Operation and Maintenance) } \\
\hline Parameters & Description & Indicators & References \\
\hline $\begin{array}{l}\text { Sustainable operations and } \\
\text { procurement }\end{array}$ & $\begin{array}{l}\text { Ensure sustainable conscious } \\
\text { operations and procurement with } \\
\text { acknowledged social and } \\
\text { environmental standards }\end{array}$ & $\begin{array}{l}\text { Adopting guidelines for sustainable } \\
\text { building operations, selecting } \\
\text { suppliers and service providers, } \\
\text { technical monitoring, maintenance, } \\
\text { and construction measures }\end{array}$ & {$[128,130,131]$} \\
\hline \multicolumn{4}{|c|}{ Economic Sustainability Parameters (Phase 5. End-of-life) } \\
\hline Parameters & Description & Indicators & References \\
\hline $\begin{array}{l}\text { Risk assessment and cost } \\
\text { security }\end{array}$ & $\begin{array}{l}\text { To assess and mitigate the } \\
\text { economic/financial risks associated } \\
\text { with decommissioning of project }\end{array}$ & $\begin{array}{l}\text { Adopting a framework for risk } \\
\text { management, which includes: } \\
\text { estimating cost of the dismantling } \\
\text { process, assessing the uncertainties } \\
\text { and financial risks with the } \\
\text { estimates of dismantling cost }\end{array}$ & {$[90,132,133]$} \\
\hline $\begin{array}{l}\text { Values of expandable } \\
\text { resources }\end{array}$ & $\begin{array}{l}\text { Devise strategies for estimating the } \\
\text { flow of building stocks }\end{array}$ & $\begin{array}{l}\text { Maintaining account of building } \\
\text { stocks that are potential expandable } \\
\text { components * }\end{array}$ & {$[90,134]$} \\
\hline $\begin{array}{l}\text { Separation, recycling, and } \\
\text { disposal }\end{array}$ & $\begin{array}{l}\text { Prudent and circular use of } \\
\text { materials and products }\end{array}$ & $\begin{array}{c}\text { Adopting framework for circular } \\
\text { use of C\&D waste * }\end{array}$ & {$[90,135-137]$} \\
\hline Tendering Process & $\begin{array}{c}\text { Contract award based on } \\
\text { parameters such as separate } \\
\text { collection rate, sorting rate, } \\
\text { recycling rate, hazardous substance } \\
\text { plan, site equipment plan, and } \\
\text { others }\end{array}$ & $\begin{array}{l}\text { Adopting a conceptual framework } \\
\text { for assessing the contractor's } \\
\text { eligibility and performance }\end{array}$ & {$[90,138]$} \\
\hline
\end{tabular}

* For further explanation refer to Appendix B.

Table 4. Pool of relevant environmental based sustainability assessment parameters for different phases of construction.

\begin{tabular}{|c|c|c|c|}
\hline \multicolumn{4}{|c|}{ Environmental Sustainability Parameters (Phase 1. Conceptual Planning and Feasibility Study) } \\
\hline Parameters & Description & Indicators & References \\
\hline $\begin{array}{l}\text { System of } \\
\text { environmental-economic } \\
\text { accounting }\end{array}$ & $\begin{array}{l}\text { Integrating economic and } \\
\text { environmental data for analysing } \\
\text { the interrelationship between } \\
\text { economy and environmental stock } \\
\text { changes }\end{array}$ & $\begin{array}{l}\text { Adopting/implementing } \\
\text { framework for assessing the trends } \\
\text { in the stocks of natural resources, } \\
\text { emissions, and discharges in the } \\
\text { environment resulting from } \\
\text { economic activities; accounting of } \\
\text { environmental preservation cost } \\
\text { and conservation cost }\end{array}$ & {$[93,94]$} \\
\hline $\begin{array}{l}\text { Environmental feasibility } \\
\text { report/environmental impact } \\
\text { assessment }\end{array}$ & $\begin{array}{l}\text { Potentials benefits and ecological } \\
\text { risks associated with the proposed } \\
\text { project }\end{array}$ & $\begin{array}{l}\text { Evaluating air, water, noise, land, } \\
\text { and other pollution monitoring, } \\
\text { prevention, and control strategies }\end{array}$ & [76,139-141] \\
\hline $\begin{array}{l}\text { Environmental management } \\
\text { plan }\end{array}$ & $\begin{array}{l}\text { Plan for controlling the } \\
\text { environmental cost associated with } \\
\text { the life cycle phases of a } \\
\text { construction }\end{array}$ & $\begin{array}{l}\text { Adopting a framework for } \\
\text { environmental cost management } \\
\text { accounting }\end{array}$ & {$[47,142]$} \\
\hline
\end{tabular}


Table 4. Cont.

\section{Environmental Sustainability Parameters (Phase 2. Design and Engineering)}

Parameters

Description

Promoting the use of materials that can be salvaged and reused aimed at sustainable consumption and production

Indicators

References

Adopting/implementing

framework for assessing the trends

in the stocks of natural resources, emissions, and discharges in the

environment resulting from

economic activities; accounting of environmental preservation cost and conservation cost

Design with considerations such as access to nature, biophilic benefit to people, occupants' access to nature outdoors, and encouraging

biodiversity within site footprints ature and the built environment

$$
\begin{gathered}
\text { biodiversity within site footp } \\
\text { and surroundings }
\end{gathered}
$$

Design for maintaining/improving indoor air quality, water quality in order to minimize health risks improving health

Design with a commitment to water efficiency, net zero life cycle

Design for tackling climate change emissions, resilience against climate change and extreme weather events across all life cycle phases
Adopting assessment framework for assessing the value of habitat

that includes estimating the quantity and quality of biodiversity gained or lost, comparing pre- and postconstruction phases

Adopting WHO Air Quality

Guidelines, ASHRAE set

benchmarks and WHO Guidelines

[68,149-152]

for drinking water quality

Adopting guidelines for net zero emissions and climate resilience with design strategies aimed at

mitigation and adaptation

Environmental Sustainability Parameters (Phase 3. Construction)

Parameters

Water use efficiency and managing local shortage crisis of building materials
Avoid usage of hazardous building materials, promote recycling and circular use of building materials
Commitment towards water reduction in material production and different construction phases

\section{Adopting a strategic framework for} adopting and promoting water saving across life cycle phases of a construction
Adopting monitoring framework towards material loop closing in construction processes with focus on: designing out the waste, using circular building products preferring refurbished, recycle, and remanufactured products

\begin{tabular}{|c|c|c|c|}
\hline Parameters & Description & Indicators & References \\
\hline $\begin{array}{l}\text { Water use efficiency and } \\
\text { managing local shortage crisis }\end{array}$ & $\begin{array}{l}\text { Ensure commitment towards water } \\
\text { demand reduction, wastewater } \\
\text { treatment, rainwater management, } \\
\text { and preserving water qualities for } \\
\text { minimizing health risks }\end{array}$ & $\begin{array}{l}\text { Adopting a strategic framework for } \\
\text { promoting water saving across life } \\
\text { cycle phases of a construction }\end{array}$ & {$[68,165-167]$} \\
\hline Solid waste management & $\begin{array}{l}\text { Ensure waste management systems } \\
\text { are in place aimed at waste } \\
\text { elimination, waste minimization, } \\
\text { and material reuse }\end{array}$ & $\begin{array}{l}\text { Adopting decision support } \\
\text { framework for solid waste } \\
\text { management postoccupancy }\end{array}$ & {$[68,70,168-170]$} \\
\hline Air quality management & $\begin{array}{c}\text { Ensure ambient air quality indoors } \\
\text { and outdoors by real time } \\
\text { monitoring }\end{array}$ & $\begin{array}{c}\text { Adopting a framework for } \\
\text { integrating air quality impacts in } \\
\text { life cycle assessment }\end{array}$ & {$[68,171,172]$} \\
\hline
\end{tabular}

Environmental Sustainability Parameters (Phase 4. Operation and Maintenance) 
Table 4. Cont.

\begin{tabular}{|c|c|c|c|}
\hline \multicolumn{4}{|c|}{ Environmental Sustainability Parameters (Phase 5. End of life) } \\
\hline Parameters & Description & Indicators & References \\
\hline Material flow balance & $\begin{array}{l}\text { C\&D waste generated during } \\
\text { demolition/decommissioning } \\
\text { phase }\end{array}$ & $\begin{array}{l}\text { Adopting a framework for } \\
\text { acounting of masses arising in } \\
\text { demolition/dismantling process, } \\
\text { maintaining inventory of massess } \\
\text { incurred, estimationg the distance, } \\
\text { and others }\end{array}$ & {$[90,173,174]$} \\
\hline $\begin{array}{l}\text { Life cycle assessment of } \\
\text { material flows }\end{array}$ & $\begin{array}{l}\text { Environmental impacts/risks } \\
\text { because of output flows, waste } \\
\text { generated, emissions, and others }\end{array}$ & $\begin{array}{l}\text { Adopting a framework for } \\
\text { estimating/preventinng } \\
\text { environmental impact } \\
\text { arising from demolition of the } \\
\text { constructed facility }\end{array}$ & {$[90,175]$} \\
\hline $\begin{array}{l}\text { Hazardous substance } \\
\text { remediation }\end{array}$ & $\begin{array}{l}\text { Hazardous substances generated } \\
\text { during } \\
\text { demolition/decommissioning } \\
\text { phase }\end{array}$ & $\begin{array}{l}\text { Adopting hazardous substance } \\
\text { remediation guidelines and } \\
\text { accounting of hazardous substances } \\
\text { separately }\end{array}$ & {$[90,176]$} \\
\hline
\end{tabular}

\subsection{A Methodological Framework for Calculating TBL Scores and Decoupling Indices for Life} Cycle Phases

Methodological frameworks provide the structure to guide users by using stages or a step by step approach. They help in improving the consistency, robustness, and reporting of the activity, the quality of the research, the standardization of approaches, and maximizing the trustworthiness of the results [177]. Figure 3 illustrates the proposed LCSA framework in six steps.

\begin{tabular}{|c|c|c|c|c|c|}
\hline $\begin{array}{c}\text { Selecting } \\
\text { assesment } \\
\text { parameters and } \\
\text { indicators for } \\
\text { different phases }\end{array}$ & $\begin{array}{c}\text { Weight } \\
\text { determination for } \\
\text { assessment } \\
\text { phases, categories } \\
\text { and parametes }\end{array}$ & $\begin{array}{c}\text { Normalization of } \\
\text { weights }\end{array}$ & $\begin{array}{l}\text { Aggregation of } \\
\text { weights }\end{array}$ & $\begin{array}{l}\text { Chain number } \\
\text { calculation }\end{array}$ & $\begin{array}{c}\text { Index } \\
\text { constrcution/ } \\
\text { classification } \\
\text { system }\end{array}$ \\
\hline
\end{tabular}

Figure 3. Steps for LCSA framework.

3.2.1. Identification of Potential Sustainability Parameters/Indicators for Life Cycle Phases of Construction and Weight Determination for Assessment Phases, Categories, and Parameters

Based on common consensus, the assessment parameters and corresponding indicators for construction phases are to be identified using suitable multicriteria decision analysis (MCDA) techniques. After finalizing assessment parameters and corresponding indicators (Tables 2-4), the weights that are to be allocated for project phases $\left(W_{k}, k=1\right.$ i.e., Conceptual Planning and Feasibility Study, $k=2$ i.e., Design and Engineering, $k=3$ i.e., Construction, $k=4$ i.e., Operation and Maintenance, and $k=5$ i.e., End of life), assessment categories ( $W_{l}, l=1$ i.e., social, $1=2$ i.e., economic, $1=3$ i.e., environment), and assessment parameters $\left(W_{m}, m=1 \ldots \mathrm{n}\right.$, where $\mathrm{n}$ is a number of assessment parameters). Yu et al. (2018) [13] follow a similar approach in their study.

\subsubsection{Benchmark/Baseline Score Matrix of Sustainability Assessment}

Setting a benchmark score or target score under each of the sustainability assessment parameters (Table 1) is a key feature in most sustainability assessment rating tools/schemes. 
A benchmark/baseline score is a product of the phase weight $\left(W_{k}\right)$, category weight $\left(W_{l}\right)$ and parameter weight $\left(W_{m}\right)$ (Equation (2)).

$$
\text { Benchmark/Baseline score }=W k * W l * \sum_{m=1}^{n} W m
$$

Similarly, Table 5 represents the benchmark or baseline score matrix. In simple words, each cell represents the maximum performance under the corresponding phase and sustainability pillar.

Table 5. Benchmark/baseline score matrix.

\begin{tabular}{|c|c|c|c|c|c|c|}
\hline Project Phase & $\begin{array}{l}\text { Conceptual Planning and } \\
\text { Feasibility Study }\end{array}$ & Design and Engineering & Construction & $\begin{array}{l}\text { Operation and } \\
\text { Maintenance }\end{array}$ & End of Life & $\begin{array}{l}\text { Life Cycle Benchmark TBL Score } \\
\text { (LCBTS) }\end{array}$ \\
\hline \multicolumn{7}{|l|}{ Sustainability Pillars } \\
\hline Social & $\mathrm{W} 1 * \mathrm{~W} 1 * \sum_{m=1}^{n} \mathrm{Wm}$ & $\mathrm{W} 2 * \mathrm{~W} 1 * \sum_{m=1}^{n} \mathrm{Wm}$ & $\mathrm{W} 3 * \mathrm{~W} 1 * \sum_{m=1}^{n} \mathrm{Wm}$ & $\mathrm{W} 4 * \mathrm{~W} 1 * \sum_{m=1}^{n} \mathrm{Wm}$ & $\mathrm{W} 5 * \mathrm{~W} 1 * \sum_{m=1}^{n} \mathrm{Wm}$ & $\mathrm{W} 1 * \sum_{k=1}^{5} \sum_{m=1}^{n} \mathrm{Wk} * \mathrm{Wm}$ \\
\hline Economic & $\mathrm{W} 1 * \mathrm{~W} 2 * \sum_{m=1}^{n} \mathrm{Wm}$ & $\mathrm{W} 2 * \mathrm{~W} 2 * \sum_{m=1}^{n} \mathrm{Wm}$ & $\mathrm{W} 3 * \mathrm{~W} 2 * \sum_{m=1}^{n} \mathrm{Wm}$ & $\mathrm{W} 4 * \mathrm{~W} 2 * \sum_{m=1}^{n} \mathrm{Wm}$ & $\mathrm{W} 5 * \mathrm{~W} 2 * \sum_{m=1}^{n} \mathrm{Wm}$ & $\mathrm{W} 2 * \sum_{k=1}^{5} \sum_{m=1}^{n} \mathrm{Wk} * \mathrm{Wm}$ \\
\hline Environment & $\mathrm{W} 1 * \mathrm{~W} 3 * \sum_{m=1}^{n} \mathrm{Wm}$ & $\mathrm{W} 2 * \mathrm{~W} 3 * \sum_{m=1}^{n} \mathrm{Wm}$ & $\mathrm{W} 3 * \mathrm{~W} 3 * \sum_{m=1}^{n} \mathrm{Wm}$ & $\mathrm{W} 4 * \mathrm{~W} 3 * \sum_{m=1}^{n} \mathrm{Wm}$ & $\mathrm{W} 5 * \mathrm{~W} 3 * \sum_{m=1}^{n} \mathrm{Wm}$ & $\mathrm{W} 3 * \sum_{k=1}^{5} \sum_{m=1}^{n} \mathrm{Wk} * \mathrm{Wm}$ \\
\hline \multirow{2}{*}{$\begin{array}{l}\text { Project Phase Benchmark } \\
\text { Sustainability Score (PPBSS) }\end{array}$} & \multirow{2}{*}{$\mathrm{W} 1 * \sum_{l=1}^{3} \sum_{m=1}^{n} \mathrm{Wl} * \mathrm{Wm}$} & \multirow{2}{*}{$\mathrm{W} 2 * \sum_{l=1}^{3} \sum_{m=1}^{n} \mathrm{~W} 1 * \mathrm{Wm}$} & \multirow{2}{*}{$\mathrm{W} 3 * \sum_{l=1}^{3} \sum_{m=1}^{n} \mathrm{Wl} * \mathrm{Wm}$} & \multirow{2}{*}{$\mathrm{W} 4 * \sum_{l=1}^{3} \sum_{m=1}^{n} \mathrm{Wl} * \mathrm{Wm}$} & \multirow{2}{*}{$\mathrm{W} 5 * \sum_{l=1}^{3} \sum_{m=1}^{n} \mathrm{Wl} * \mathrm{Wm}$} & $\sum_{\mathrm{K}=11}^{5} \sum_{=1}^{3} \sum_{\mathrm{m}=1}^{\mathrm{n}} \mathrm{Wk} * \mathrm{Wl} * \mathrm{Wm}$ \\
\hline & & & & & & $\begin{array}{c}\text { Cumulative Benchmark } \\
\text { Sustainability Score (CBSS) }\end{array}$ \\
\hline
\end{tabular}

\subsubsection{Computation of Normalized Performance Score Matrix of Sustainability Assessment}

In sustainability assessment, the rationale underpinning the normalization of scores is to transform the measurement of different assessment parameters/indicators to a common unit, and to ease out the inclusion for aggregate sustainability assessment scores. For example, if the benchmark (maximum) score/credit points for an assessment category (social) is 24 and, during the assessment process, a project obtains 15 credit points out of 24 maximum available points, then the normalized social score is $(15 / 24=0.625)$ (Equation (3)).

Normalized performance score $\left(P_{n o r}\right)=$ Performance assessment score/Performance benchmark score

where,

Performance assessment score is the score obtained by a project in a particular assessment parameter and Performance benchmark score (Equation (2)) is the maximum score that can be obtained in a particular assessment parameter. It may be noted that other approaches towards normalization can also be adopted and the present method has been used in the absence of more definitive and universally acceptable methodology.

Similarly, Table 6 represents the normalized performance score matrix; each cell represents performance under the corresponding phase and sustainability pillar. 
Table 6. Normalized performance score matrix.

\begin{tabular}{|c|c|c|c|c|c|c|}
\hline Project Phase & Conceptual Planning and & Design and Engineering & Construction & Operation and & End of Life & Life Cycle TBL Score (LCTS) \\
\hline \multicolumn{7}{|l|}{ Sustainability Pillars } \\
\hline Social & $\sum_{m=1}^{n} \mathrm{P}$ nor $1,1, \mathrm{~m}$ & $\sum_{m=1}^{n}$ P nor $2,1, \mathrm{~m}$ & $\sum_{m=1}^{n} \mathrm{P}$ nor $3,1, \mathrm{~m}$ & $\sum_{m=1}^{n} \mathrm{P}$ nor $4,1, \mathrm{~m}$ & $\sum_{m=1}^{n} \mathrm{P}$ nor $5,1, \mathrm{~m}$ & $\sum_{k=1}^{5} \sum_{m=1}^{n} \mathrm{P}$ nork, $1, \mathrm{~m}$ \\
\hline Economic & $\sum_{m=1}^{n}$ P nor $1,2, \mathrm{~m}$ & $\sum_{m=1}^{n} \mathrm{P}$ nor $2,2, \mathrm{~m}$ & $\sum_{m=1}^{n} \mathrm{P}$ nor $3,2, \mathrm{~m}$ & $\sum_{m=1}^{n} \mathrm{P}$ nor $4,2, \mathrm{~m}$ & $\sum_{m=1}^{n} \mathrm{P}$ nor $5,2, \mathrm{~m}$ & $\sum_{k=1}^{5} \sum_{m=1}^{n} \mathrm{P}$ nork, $2, \mathrm{~m}$ \\
\hline Environment & $\sum_{m=1}^{n} \mathrm{P}$ nor $1,3, \mathrm{~m}$ & $\sum_{m=1}^{n} \mathrm{P}$ nor $2,3, \mathrm{~m}$ & $\sum_{m=1}^{n} \mathrm{P}$ nor $3,3, \mathrm{~m}$ & $\sum_{m=1}^{n} \mathrm{P}$ nor $4,3, \mathrm{~m}$ & $\sum_{m=1}^{n}$ P nor $5,3, \mathrm{~m}$ & $\sum_{k=1}^{5} \sum_{m=1}^{n} \mathrm{P}$ nork, $2, \mathrm{~m}$ \\
\hline \multirow{2}{*}{$\begin{array}{l}\text { Project Phase Sustainability } \\
\text { Score (PPSS) }\end{array}$} & \multirow{2}{*}{$\sum_{l=1}^{3} \sum_{m=1}^{n} \mathrm{P}$ nor $1,1, \mathrm{~m}$} & \multirow{2}{*}{$\sum_{l=1}^{3} \sum_{m=1}^{n} \mathrm{P}$ nor $2,1, \mathrm{~m}$} & \multirow{2}{*}{$\sum_{l=1}^{3} \sum_{m=1}^{n} \mathrm{P}$ nor $2,1, \mathrm{~m}$} & \multirow{2}{*}{$\sum_{l=1}^{3} \sum_{m=1}^{n} \mathrm{P}$ nor $2,1, \mathrm{~m}$} & \multirow{2}{*}{$\sum_{l=1}^{3} \sum_{m=1}^{n} \mathrm{P}$ nor $2, \mathrm{l}, \mathrm{m}$} & $\sum_{K=1}^{5} \sum_{1=1}^{3} \sum_{m=1}^{\mathrm{n}} \mathrm{P}$ nork, $1, \mathrm{~m}$ \\
\hline & & & & & & $\begin{array}{l}\text { Cumulative Sustainability Score } \\
\text { (CSS) }\end{array}$ \\
\hline
\end{tabular}

3.2.4. Chain Numbers of Performance Score Matrix of Sustainability Assessment

The chain number method is commonly employed in econometric analysis, in which value of any given period is related to its immediate predecessor value (values expressed as against preceding value $=100$ or 1) [178]. Similarly, chain numbers for social well-being, environmental well-being, and environmental pressure (1-normalized environmental score) (Equation (4)) can be calculated by using a simple aggregative method, representing the sustainability performance of a particular phase of construction with respect to the preceding phase of construction. For example, in Table 9, Case-1, if the normalized social score in the preconstruction phase, as expressed, is $15 / 24=0.625$ and the normalized social score in the construction phase, as expressed, is $(14 / 24=0.583)$ then the chain index (SOPn) for the preconstruction and construction phases will be $(0.625 / 0.625=1)$ and $(0.583 / 0.625=0.93)$, respectively (Equation (5)).

$$
\text { Environmental pressure }=1-\text { Normalized environment score }
$$

Chain Index $=$ Normalized performance score of current phase/Normalized performance score of base phase

3.2.5. Computation of Phase Well-Being Decoupling Index and Phase Impact Decoupling Index

Examining the importance of decoupling analysis in sustainability assessment and based on decoupling theory, this step involves the development of two decoupling indices, namely: (1) phase well-being decoupling index (2) phase impact decoupling index. The phase well-being decoupling index estimates if there is an increase in social well-being corresponding to the environmental pressure (1-normalized environmental score) for different phases (Equation (6)). The phase impact decoupling index estimates if there is an increase in economic performance corresponding to the environmental pressure (1-normalized environmental score) for different phases (Equation (7)).

$$
\begin{gathered}
\text { Phase well-being decoupling index of stage } K\left(P W B D I_{K}\right)=S O P n / E N P n \\
\text { Phase impact decoupling index of stage } K\left(P I D I_{K}\right)=E C P n / E N P n
\end{gathered}
$$

where,

$S O P n$ is the chain index of the normalized social performance score of one phase to the next phase;

$E C P n$ is the chain index of the normalized economic performance score of one phase to the next phase;

$E N P n$ is the chain index of the normalized environmental pressure score of one phase to the next phase; 
$P W B D I_{K}$ is the ratio of the change in social well-being performance to the change in environmental pressure upon moving from one phase to the next phase;

$\mathrm{PIDI}_{K}$ is the ratio of the change in social well-being performance to the change in environmental pressure upon moving from one phase to the next phase.

3.2.6. Classification System Based on TBL Scores and Decoupling Indices for Different Life Cycle Phases

Table 7 presents the description of the different cases of coupling and decoupling that are possible after computation of the phase well-being and impact decoupling indices. Li et al. (2019) [179] provide a similar kind of cut off values of decoupling degrees. Figure 4 is a graphical representation of the state of sustainability (ideal, permitted, and prohibited) that arise from different combinations of $\mathrm{PWBDI}_{K}$ and $\mathrm{PIDI}_{K}$, as given in Table 7 .

Table 7. Description of different types of coupling/decoupling based on $\mathrm{PWBDI}_{\mathrm{K}}$ and $\mathrm{PIDI}_{\mathrm{K}}$.

\begin{tabular}{|c|c|c|c|c|}
\hline \multicolumn{2}{|c|}{ Type of Coupling/Decoupling } & Possible Cases & Remark & $\begin{array}{c}\text { State of } \\
\text { Sustainability }\end{array}$ \\
\hline \multirow{3}{*}{ PWBDI k > 1} & $\begin{array}{l}\text { Absolute well-being } \\
\text { decoupling }\end{array}$ & SOPn $>1$, ENPn $<1$ & $\begin{array}{l}\text { Increase in social well-being but } \\
\text { decrease in environmental } \\
\text { pressure }\end{array}$ & \multirow{2}{*}{ Ideal state } \\
\hline & $\begin{array}{l}\text { Relative well-being } \\
\text { decoupling }\end{array}$ & SOPn $>1$, ENPn $>1$ & $\begin{array}{l}\text { Increase in social well-being } \\
\text { exceeds increase in environmental } \\
\text { pressure }\end{array}$ & \\
\hline & $\begin{array}{l}\text { Contract well-being } \\
\text { decoupling }\end{array}$ & SOPn $<1$, ENPn $<1$ & $\begin{array}{l}\text { Decrease in social well-being is } \\
\text { less than the decrease in } \\
\text { environmental pressure }\end{array}$ & Permitted state \\
\hline \multirow{3}{*}{ PWBDI k < 1} & $\begin{array}{l}\text { Expansive well-being } \\
\text { recoupling }\end{array}$ & SOPn $>1$, ENPn $>1$ & $\begin{array}{l}\text { An increase in social well-being is } \\
\text { coupled with increasing } \\
\text { environmental pressure }\end{array}$ & \multirow{3}{*}{ Prohibited state } \\
\hline & $\begin{array}{l}\text { Absolute well-being } \\
\text { recoupling }\end{array}$ & SOPn $<1$, ENPn $>1$ & $\begin{array}{l}\text { Decrease in social well-being with } \\
\text { increase in environmental pressure }\end{array}$ & \\
\hline & $\begin{array}{l}\text { Relative well-being } \\
\text { recoupling }\end{array}$ & $\mathrm{SOPn}<1, \mathrm{ENPn}<1$ & $\begin{array}{l}\text { Decrease in social well-being is } \\
\text { more than the decrease in } \\
\text { environmental pressure }\end{array}$ & \\
\hline \multirow{3}{*}{ PIDI k > 1} & $\begin{array}{l}\text { Absolute impact } \\
\text { decoupling }\end{array}$ & ECPn $>1$, ENPn $<1$ & $\begin{array}{l}\text { An increase in economic } \\
\text { well-being but decrease in } \\
\text { environmental pressure }\end{array}$ & \multirow[b]{2}{*}{ Ideal state } \\
\hline & $\begin{array}{l}\text { Relative impact } \\
\text { decoupling }\end{array}$ & $\mathrm{ECPn}>1, \mathrm{ENPn}>1$ & $\begin{array}{l}\text { An increase in economic } \\
\text { well-being exceeds increase in } \\
\text { environmental pressure }\end{array}$ & \\
\hline & $\begin{array}{l}\text { Contract impact } \\
\text { decoupling }\end{array}$ & ECPn $<1$, ENPn $<1$ & $\begin{array}{l}\text { Decrease in economic well-being is } \\
\text { less than the decrease in } \\
\text { environmental pressure }\end{array}$ & Permitted state \\
\hline \multirow{3}{*}{ PIDI k < 1} & $\begin{array}{l}\text { Expansive impact } \\
\text { recoupling }\end{array}$ & ECPn $>1$, ENPn $>1$ & $\begin{array}{c}\text { An increase in economic } \\
\text { well-being is coupled with } \\
\text { increasing environmental pressure }\end{array}$ & \multirow{3}{*}{ Prohibited state } \\
\hline & $\begin{array}{l}\text { Absolute impact } \\
\text { recoupling }\end{array}$ & $\mathrm{ECPn}<1, \mathrm{ENPn}>1$ & $\begin{array}{l}\text { Decrease in economic well-being } \\
\text { with increase in environmental } \\
\text { pressure }\end{array}$ & \\
\hline & $\begin{array}{l}\text { Relative impact } \\
\text { recoupling }\end{array}$ & ECPn $<1$, ENPn $<1$ & $\begin{array}{l}\text { Decrease in economic well-being is } \\
\text { less than the decrease in } \\
\text { environmental pressure }\end{array}$ & \\
\hline
\end{tabular}




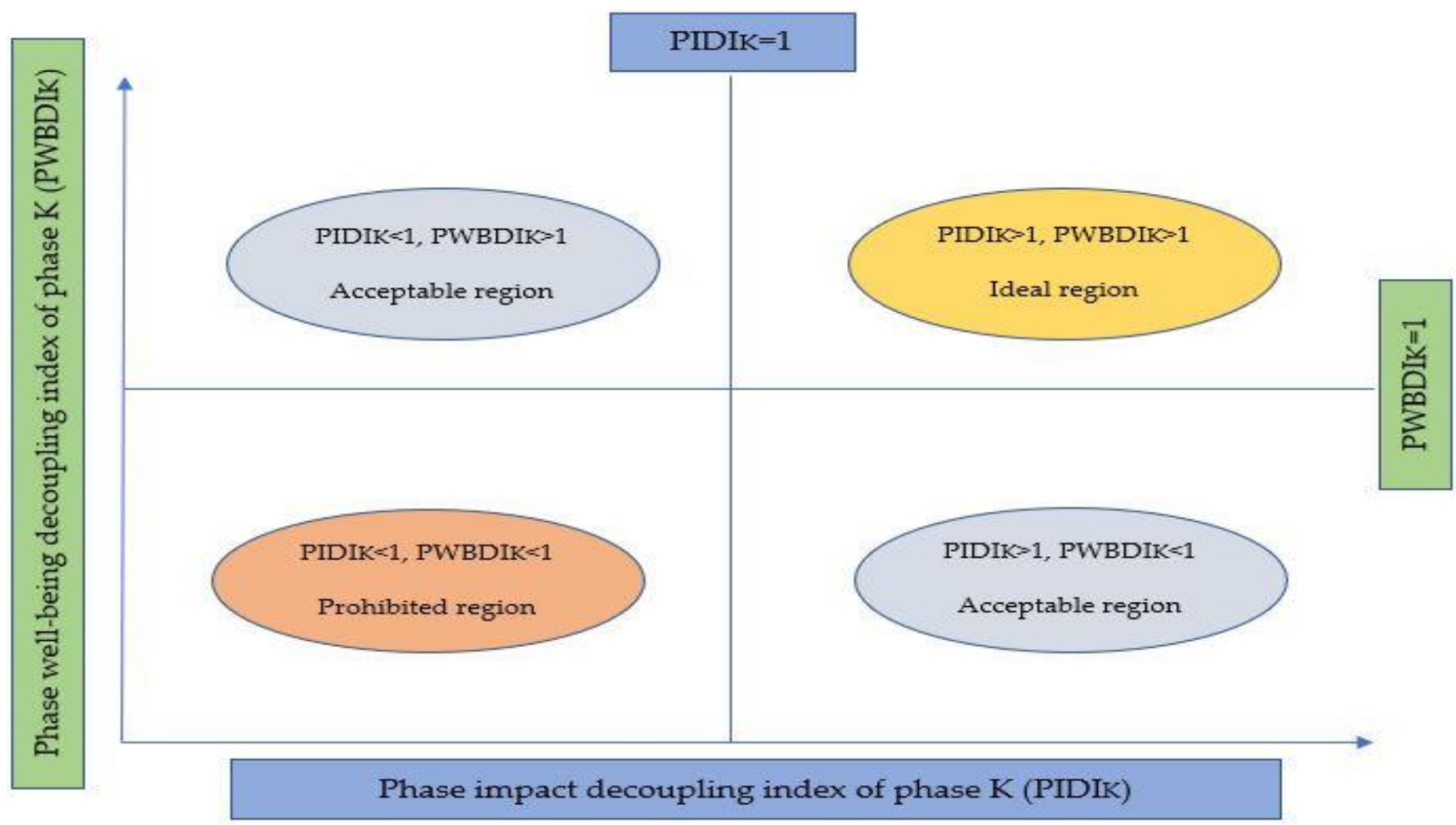

Figure 4. Categorization of states in sustainability based on phase well-being and phase impact decoupling indices.

\section{Applicability of Proposed Methodological Framework}

This section presents the details of applying a TBL based sustainability assessment criteria, as given in Table 8, for three hypothetical cases and the related computations for the phase well-being decoupling index $\left(\mathrm{PWBDI}_{\mathrm{K}}\right)$ and phase impact decoupling index $\left(\mathrm{PIDI}_{\mathrm{K}}\right)$, as given in Table 9. The criteria chosen in the present formulation are based on the GRIHA Precertification scheme and GRIHA v.2019, a justification for which is also included for completeness.

Table 8. Benchmark score and performance score matrix of the three cases.

\begin{tabular}{|c|c|c|c|c|c|c|c|c|}
\hline \multirow{3}{*}{$\begin{array}{c}\text { Sustainability } \\
\text { Assessment Parameters }\end{array}$} & \multicolumn{4}{|c|}{ Pre-Construction Phase } & \multicolumn{4}{|c|}{ Construction Phase } \\
\hline & \multirow{2}{*}{$\begin{array}{l}\text { Benchmark } \\
\text { Score }\end{array}$} & \multicolumn{3}{|c|}{ Performance Score } & \multirow{2}{*}{$\begin{array}{l}\text { Benchmark } \\
\text { Score }\end{array}$} & \multicolumn{3}{|c|}{ Performance Score } \\
\hline & & Case-1 & Case-2 & Case-3 & & Case-1 & Case-2 & Case-3 \\
\hline So-1: Sustainable Site & & & & & & & & \\
\hline $\begin{array}{l}\text { Planning-Green } \\
\text { Infrastructure } \\
\text { So-2: Occupant }\end{array}$ & 3 & 2 & 3 & 3 & 3 & 2 & 3 & 2 \\
\hline $\begin{array}{l}\text { Comfort-Visual } \\
\text { Comfort }\end{array}$ & 4 & 3 & 3 & 4 & 4 & 3 & 2 & 2 \\
\hline $\begin{array}{l}\text { So-3: Occupant } \\
\text { Comfort-Thermal and } \\
\text { Acoustic Comfort } \\
\text { So-4: Occupant }\end{array}$ & 2 & 1 & 0 & 2 & 2 & 1 & 1 & 2 \\
\hline $\begin{array}{l}\text { Comfort-Indoor Air } \\
\text { Quality }\end{array}$ & 6 & 4 & 2 & 5 & 6 & 4 & 3 & 3 \\
\hline $\begin{array}{c}\text { So-5: Socio-Economic } \\
\text { Strategies-Safety and } \\
\text { Sanitation for } \\
\text { Construction Workers } \\
\text { So-5: Socioeconomic }\end{array}$ & 1 & 1 & 1 & 1 & 1 & 1 & 1 & 1 \\
\hline $\begin{array}{l}\text { Strategies-Universal } \\
\text { Accessibility } \\
\text { So-6: Socioeconomic }\end{array}$ & 2 & 1 & 1 & 2 & 2 & 1 & 1 & 2 \\
\hline $\begin{array}{c}\text { Strategies-Dedicated } \\
\text { Facilities for Service } \\
\text { Staff }\end{array}$ & 2 & 1 & 1 & 2 & 2 & 1 & 1 & 2 \\
\hline
\end{tabular}


Table 8. Cont.

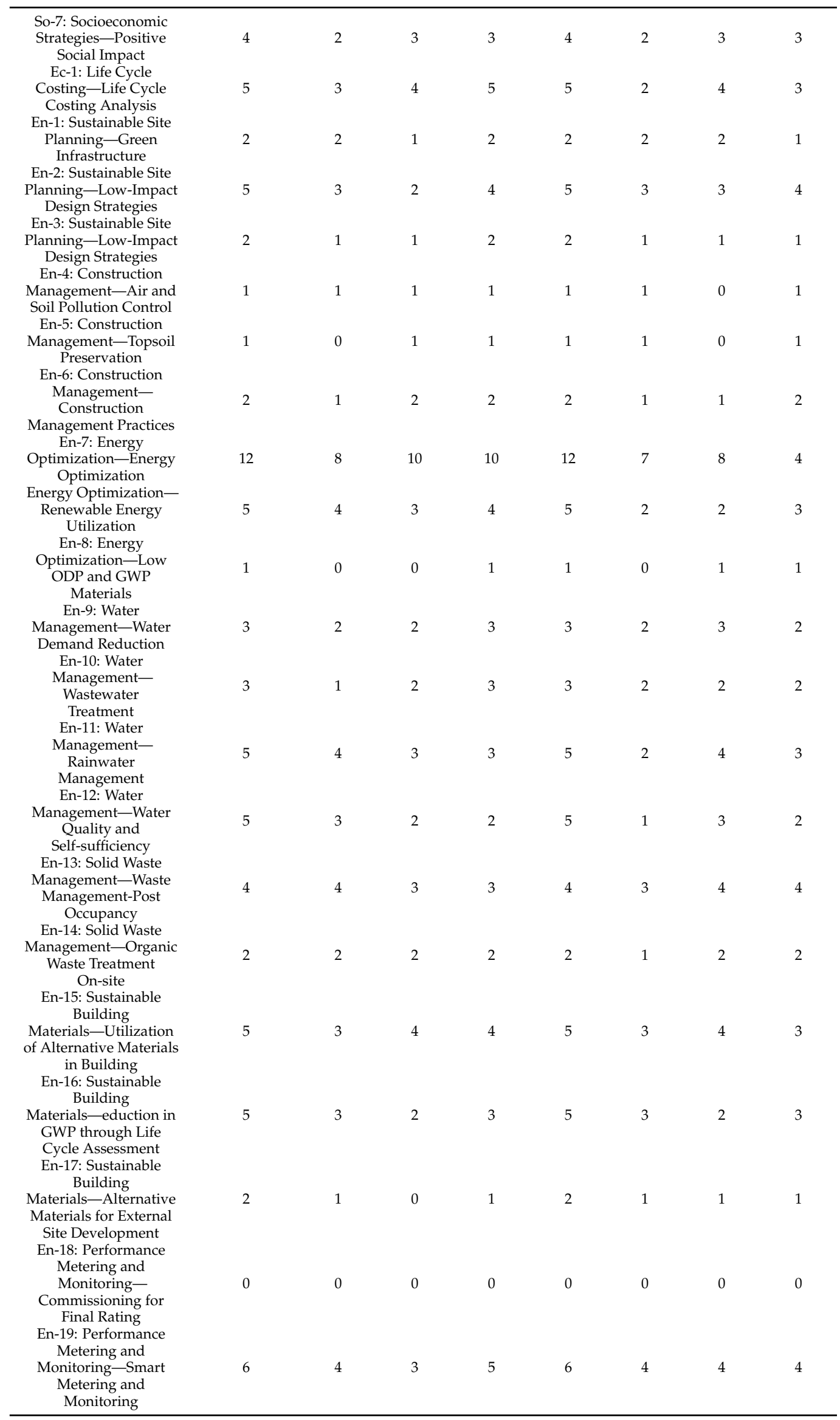


Table 8. Cont.

\begin{tabular}{|c|c|c|c|c|c|c|c|c|}
\hline $\begin{array}{l}\text { En-20: Performance } \\
\text { Metering and } \\
\text { Monitoring-Operation } \\
\text { and Maintenance } \\
\text { Protocol }\end{array}$ & 0 & 0 & 0 & 0 & 0 & 0 & 0 & 0 \\
\hline
\end{tabular}

Table 9. Computation of phase well-being decoupling index and phase impact decoupling index for the three cases.

\begin{tabular}{|c|c|c|c|c|c|c|}
\hline & \multicolumn{2}{|c|}{ Case-1 } & \multicolumn{2}{|c|}{ Case-2 } & \multicolumn{2}{|c|}{ Case-3 } \\
\hline & $\begin{array}{l}\text { Pre- } \\
\text { Construction } \\
\text { Phase }\end{array}$ & $\begin{array}{c}\text { Construction } \\
\text { Phase }\end{array}$ & $\begin{array}{l}\text { Pre- } \\
\text { Construction } \\
\text { Phase }\end{array}$ & $\begin{array}{c}\text { Construction } \\
\text { Phase }\end{array}$ & $\begin{array}{l}\text { Pre- } \\
\text { Construction } \\
\text { Phase }\end{array}$ & $\begin{array}{c}\text { Construction } \\
\text { Phase }\end{array}$ \\
\hline Social Score & 15 & 14 & 22 & 15 & 15 & 17 \\
\hline $\begin{array}{l}\text { Economic } \\
\text { Score }\end{array}$ & 3 & 4 & 5 & 2 & 4 & 3 \\
\hline $\begin{array}{c}\text { Environment } \\
\text { Score }\end{array}$ & 47 & 44 & 56 & 38 & 47 & 44 \\
\hline $\begin{array}{l}\text { Normalized } \\
\text { Social Score }\end{array}$ & 0.625 & 0.583 & 0.92 & 0.625 & 0.625 & 0.71 \\
\hline $\begin{array}{l}\text { Chain Index } \\
\text { (SOPn) }\end{array}$ & 1.00 & 0.93 & 1.00 & 0.68 & 1.00 & 1.14 \\
\hline \multicolumn{7}{|l|}{ Normalized } \\
\hline $\begin{array}{l}\text { Economic } \\
\text { Score }\end{array}$ & 0.60 & 0.80 & 1.00 & 0.40 & 0.80 & 0.60 \\
\hline $\begin{array}{l}\text { Chain Index } \\
\text { (ECPn) }\end{array}$ & 1.00 & 1.33 & 1.00 & 0.40 & 1.00 & 0.75 \\
\hline \multicolumn{7}{|l|}{ Normalized } \\
\hline $\begin{array}{c}\text { Environment } \\
\text { Score }\end{array}$ & 0.66 & 0.62 & 0.79 & 0.54 & 0.66 & 0.62 \\
\hline $\begin{array}{l}\text { Normalized } \\
\text { Environmen- } \\
\text { tal Pressure } \\
\text { Score }\end{array}$ & 0.34 & 0.38 & 0.21 & 0.46 & 0.34 & 0.38 \\
\hline $\begin{array}{l}\text { Chain Index } \\
\text { (ENPn) }\end{array}$ & 1.00 & 1.12 & 1.00 & 2.19 & 1.00 & 1.12 \\
\hline $\begin{array}{l}\text { Cumulative } \\
\text { Score }\end{array}$ & 65 & 62 & 83 & 55 & 66 & 64 \\
\hline $\begin{array}{l}\text { \# GRIHA } \\
\text { rating }\end{array}$ & $* * *$ & $* * *$ & $* * * *$ & $* *$ & $* * *$ & $* * *$ \\
\hline $\begin{array}{l}\text { Chain } \\
\text { Number }\end{array}$ & 1.00 & 0.95 & 1.00 & 0.66 & 1.00 & 0.64 \\
\hline PWBDI & \multicolumn{2}{|c|}{0.83} & \multicolumn{2}{|c|}{0.31} & \multicolumn{2}{|c|}{1.02} \\
\hline Remark & \multicolumn{2}{|c|}{$\begin{array}{l}\text { Decrease in social well-being } \\
\text { with the increase in } \\
\text { environmental pressure }\end{array}$} & \multicolumn{2}{|c|}{$\begin{array}{l}\text { Decrease in social well-being } \\
\text { with the increase in } \\
\text { environmental pressure }\end{array}$} & \multicolumn{2}{|c|}{$\begin{array}{l}\text { An increase in social well-being } \\
\text { exceeds the increase in } \\
\text { environmental pressure }\end{array}$} \\
\hline PIDI & \multicolumn{2}{|c|}{$1.19^{1}$} & \multicolumn{2}{|c|}{0.18} & \multicolumn{2}{|c|}{$0.67^{1}$} \\
\hline Remark & \multirow{2}{*}{\multicolumn{2}{|c|}{$\begin{array}{l}\text { An increase in economic } \\
\text { well-being exceeds the increase } \\
\text { in environmental pressure }\end{array}$}} & \multirow{2}{*}{\multicolumn{2}{|c|}{$\begin{array}{c}\text { Decrease in economic } \\
\text { well-being with the increase in } \\
\text { environmental pressure } \\
\text { Prohibited region }\end{array}$}} & \multirow{2}{*}{\multicolumn{2}{|c|}{$\begin{array}{c}\text { Decrease in economic } \\
\text { well-being with the increase in } \\
\text { environmental pressure } \\
\text { Acceptable region }\end{array}$}} \\
\hline Categorization & & le region & & & & le region \\
\hline
\end{tabular}

\# “*” in the different columns refers to the rating as per GRIHA. For example, “***” is three star which is given as "****".

Apart from the authors' regional context and understanding of the industry, some of the other important reasons for selecting the GRIHA's criteria for use in the proposed framework are explained in the following paragraphs:

1. According to the latest report of IPCC (2021) [180], we are already on a trajectory towards a 1.2 degrees Centigrade increase and we must act immediately to meet the 1.5 degrees Centigrade target, highlighting the urgency of this issue. The solutions are clear but the willingness to implement solutions is still lacking. These solutions should focus on long term outcomes and impacts, focusing on inclusive and green economies, prosperity, cleaner air, and better health.

2. At present, more than $50 \%$ of the population live in cities and this is expected to grow to $70 \%$ by 2050 . The urban population of India ( $17.7 \%$ of the world's population) has been rising sharply over the past decades and is projected to reach 9.9 billion by 2050 [181]. Rapid urbanization aimed at economic growth in developing regions of the world (mostly in Africa, Latin America, and Asia) creates unprecedented challenges on environmental and socio-economic fronts. As stated by the GRIHA Council, "as 
per international commitments, India plans to reduce its energy intensity by $33 \%-$ $35 \%$ by 2030 [182]. Green building design, construction and operation will play a critical role as they are synonymous to both sustainable construction and assured high performance".

3. Further, the GRIHA Council also stated that, "GRIHA - with its commitment towards Intended Nationally Determined Contributions (INDCs) has been instrumental in recent years for good practices and innovative solution for enhancing resource efficiency in the building sector. GRIHA's large scale adoption will have enormous potential in addressing challenges". However, like any other assessment tools/schemes, GRIHA, too, has scope for improvement in its assessment framework (as discussed in Section 2.2.1). The endeavor to create large scale impact by proposing a new assessment framework with modifications in the existing assessment framework and mapping projects using well-being and impact decoupling indices (Figure 3) will be instrumental in progressing towards true sense of sustainability.

4. The GRIHA rating tool has separate schemes for assessing the sustainability performance of the preconstruction (planning, feasibility, design and engineering) and construction (new construction) phases. Though the assessment parameters are defined from a TBL perspective, the weights allocated to different dimensions are not transparent, and are not based on a clear logical set of parameters.

5. In addition, to test the proposed life cycle assessment framework incorporating TBL and decoupling indices (phase well-being and impact well-being), TBL based sustainability scores for at least two phases are required. As GRIHA allows the same projects to be rated against its Pre-certification and New-Construction schemes, providing the TBL based assessment scores for the same project in different life cycle phases. This presents a good opportunity for testing the proposed framework with slight modifications in the assessment scores obtained by the projects in their different life cycle phases.

The GRIHA Precertification scheme represents the sustainability assessment of preconstruction phase, i.e., conceptual planning and feasibility study and design and engineering, clubbed together. The GRIHA v.2019 scheme represents the sustainability assessment of the construction phase. The benchmark scores for the different assessment criteria (Table 8) in these schemes have been developed based on the analytical hierarchical process (AHP) (GRIHA v.2019 Abridged Manual, 2019) [70]. Table 8 also shows the assumed performance score for three hypothetical cases in the preconstruction and construction phases. As mentioned above, the computations using these assumed values for the different indices, as defined in Equations (6) and (7), have been shown in Table 9.

\section{Conclusions}

Construction assessment schemes and tools have been widely criticized for ignoring the life cycle assessment of social and economic dimensions in their sustainability frameworks. Moreover, decoupling and its assessment, which is acknowledged as a core of sustainability frameworks, is also not captured by any of these sustainability assessment tools/schemes. This study is an attempt to answer the above limitations of current sustainability assessment tools/schemes by developing a methodological framework for the life cycle sustainability assessment of construction, incorporating TBL and decoupling principles. The main conclusions/findings from this study can be summarized as follows:

1. Construction, especially in the developing world, still operates on take, make, waste (linear/coupled) systems. Life cycle sustainability assessment (LCSA) frameworks that ensure continued economic and social well-being, but with reduced environmental pressures, are missing, i.e., decoupled systems have a clear role to play.

2. Comparative analysis of GRIHA (India), LEED-IGBC (India), Green Star (Australia), BCA Green Mark (Singapore), DGNB (Germany), CASBEE (Japan), BREEAM (UK), Green Globes (Canada), BEAM Plus (Hong Kong), and GSAS (Gulf countries) from a TBL perspective shows that most of these assessment tools are biased towards 
environmental sustainability evaluation and have allocated 69 percent of total credit points, on average. Although most of these assessment tools try to evaluate social sustainability by allocating 25 percent of the total credit points, on average, economic sustainability has been mostly neglected in the sustainability assessment.

3. Only the DGNB (Germany) system was observed to have a balance in their approach for allocating credit points across the three dimensions of sustainability. It allocated 30,30 , and 40 percent of total credit points towards evaluating social, economic, and environmental dimensions of sustainability, respectively (Table 1). However, irrespective of initial weights across TBL dimensions, these rating tools provide classification systems based on an aggregate scoring system (except CASBEE) and, therefore, they lack in evaluating interactions among different pillars of sustainability.

4. Credit criteria, such as: ethical considerations, a system of environmental-economic accounting, targeted incentives, long term value to the society, design for harmony with nature and the built environment, and design for tackling climate change, are some of the key criteria that are not explicitly included in rating tools/schemes but are found in the literature. For optimized sustainability evaluation, these criteria should be included in the current sustainability rating tools/schemes (Tables 2-4).

5. DGNB (Germany) is the only rating tool that has a sustainability assessment scheme for rating the decommissioning/deconstruction phase of a building project (pilot mode). Considering the importance of the decommissioning phase in the building life cycle, TBL based sustainability assessment criteria for the decommissioning phase needs to be considered. Green building councils (GBCs) should focus on developing assessment schemes/tools and respective criteria for the decommissioning phase, taking account of the regional context.

6. The current study proposes a methodological framework for calculating life cycle based TBL scores and decoupling indices. Two decoupling indices are proposed, i.e., phase well-being decoupling index $\left(\mathrm{PWBDI}_{\mathrm{K}}\right)$ (Equation (6) and phase impact decoupling index $\left(\mathrm{PIDI}_{\mathrm{K}}\right)$ (Equation (7), for supporting TBL-based life cycle assessment. These developed decoupling indices specifically estimate the interdependence of human well-being, economic growth, and environmental pressure associated with construction projects. Construction projects in their different life cycle phases can be mapped using computed $\mathrm{PWBDI}_{\mathrm{K}}$ and $\mathrm{PIDI}_{\mathrm{K}}$ by referring to Table 7 and Figure 4 of this study.

7. The sustainability assessment criteria from the GRIHA Precertification and GRIHA v.2019 schemes, representing assessment criteria of pre-construction and construction phase, respectively, were used to illustrate the calculations in the proposed LCSA framework. For three hypothetical cases, $\mathrm{PWBDI}_{\mathrm{K}}$ and $\mathrm{PIDI}_{\mathrm{K}}$ were computed representing projects moving from the preconstruction phase to the construction phase. It was highlighted that for case- 1 and case-3, their GRIHA rating $\left(^{* * *}\right)$ was maintained after sustainability evaluation of the preconstruction and construction phases. It can be seen from Tables 8 and 9 that the performance of case- 2 changed from $\left(^{* * *}\right)$ to $\left(^{* *}\right)$ when moving from the preconstruction phase to the construction phase. This can be taken to be an example of how the proposed framework can be used to ensure that projects do not lose track when moving from one phase to another.

8. The PWBDI value for case-1 indicates that there is a decrease in social well-being with an increase in environmental pressure, and the PIDI value for case- 1 indicates that there is an increase in economic well-being that exceeds the increase in environmental pressure. The PWBDI value for case- 2 indicates that there is a decrease in social well-being with an increase in environmental pressure and the PIDI value for case- 2 indicates that there is a decrease in economic well-being with an increase in environmental pressure. The PWBDI value for case- 3 indicates that there is an increase in social well-being that exceeds the increase in environmental pressure and the PIDI value for case-3 indicates that there is a decrease in economic well-being with an increase in environmental pressure (Tables 7 and 9). However, based on aggregate 
scores, different scenarios are possible and, moreover, when these projects move from one phase to another phase, they can behave differently, irrespective of their base phase performance, as illustrated by the PWBDI and PIDI for GRIHA cases. For a better understanding of the proposed PWBDI/PIDI approach an illustrative example has been included in Appendix C.

The proposed methodological framework not only encapsulates a TBL based life cycle sustainability approach in construction, but also ensures a monitoring mechanism for the same using decoupling indices. Given the fact that the parameters involved in the operation and decommissioning phases could be quite different from those in the preconstruction and construction phases (as illustrated in Tables 2-4), the present study is confined to the preconstruction and construction phases only. It is agreed that scores derived from a "real" project would be more valuable and convincing. However, in the absence of such (real) data, the present study only presents the methodological framework and includes a "proof of concept" verification or validation on the basis of assumed (but "reasonable") values. The authors continue to strive to collect/access real data in their future works.

Author Contributions: Conceptualization, S.S., U.I.R. and S.M.; methodology, S.S. and S.M.; validation S.S., U.I.R. and S.M.; formal analysis, U.I.R. and S.M.; investigation, S.S.; resources, S.S.; data curation, S.S.; writing-original draft preparation, S.S.; writing-review and editing, U.I.R. and SM; supervision, U.I.R. and S.M.; project administration, S.S. All authors have read and agreed to the published version of the manuscript.

Funding: This research received no external funding.

Institutional Review Board Statement: This research used secondary data, so no ethics approval was needed.

Informed Consent Statement: Not applicable.

Data Availability Statement: No such data was used. All data used was publicly available from green building websites.

Conflicts of Interest: The authors declare no conflict of interest.

\section{Appendix A}

Methodology for Detailed Division of Credits from TBL Consideration in Different Rating Tools/Schemes

Ten well-established rating tools/schemes representing different regions of the world for studying their approach to the TBL concept of sustainability were selected, namely, GRIHA (India), LEED-IGBC (India), Green Star (Australia), BCA Green Mark (Singapore), DGNB (Germany), CASBEE (Japan), BREEAM (UK), Green Globes (Canada), GBI (Malaysia), GSAS (Gulf countries). There are different types of schemes developed by these rating agencies to rate different typologies of construction projects. Keeping in mind the criticality and scale of adoption, only schemes that certify non-residential (newconstructions) under these rating agencies were chosen for critical evaluation in this study. And, a comparison based on weights of TBL (social, economic, and environment) among these tools is presented Table 1 of the manuscript.

The following text outlines the method adopted in this study for evaluating a comprehensive performance of projects on the basis of scores obtained on the social, economic, and environmental fronts.

1. The classification of the credit points for an individual parameter into social, economic, or environmental dimension was carried out using a subjective judgement based on available literature. This has been explained in Section 2.2.1 and Tables 2-4. of the manuscript. The user/technical manuals for each of these mentioned schemes were also referred.

2. However, in cases when a parameters/indicator was judged to belong to more than one dimension, the credits assigned to that particular category were divided equally 
between/among the different dimensions of sustainability the parameter contributes. For example, in the DGNB classification system, under the category of Technical Quality, "Ease of cleaning building components" is one of the assessment parameters. Where the detailed description for this parameter at Criteria "Ease of cleaning building components" I DGNB System (dgnb-system.de), says "The issue of how a building structure can be cleaned has a significant effect on the costs and environmental impact of a building during its use. Surfaces that can be easily cleaned require less cleaning agents and result in lower cleaning costs". Now, this parameter was qualitatively judged to belong to both - the economic and environmental heads, and therefore the allocated credit (1.66) for this parameter was equally assigned to the economic and environmental heads (i.e., it was taken to be 0.83 and 0.83 for further computations in both these heads).

3. In the case of DGNB (Germany), which declares a total of six categories - environment, economic, socio-culture, technical quality, process quality, and site quality. The document also mentions the respective parameters under each of these categories. Now, for the purpose of the present study, whereas the parameters for the first three were adopted as such, the parameters for the latter three were assigned to the former three using qualitative judgement.

4. Some of the assessment parameters/indicators under these rating tools/schemes are given as prerequisite. For example, In Part 3— "Resource Stewardship" of Green Mark (Singapore), water efficient fittings are listed as a prerequisite. The schemes expect compliance with respect to these as a minimum, and do not award any points for that in their scoring scheme. This approach has been adopted in the present study also and such parameters have been excluded from award of any credit points under these schemes.

GRIHA v.2019 Abridged Manual.

\begin{tabular}{|c|c|c|c|c|}
\hline \multirow[t]{2}{*}{ GRIHA } & \multirow[t]{2}{*}{ Maximum Points } & \multicolumn{3}{|c|}{ Dimension of Sustainability } \\
\hline & & Social & Economic & Environment \\
\hline \multicolumn{5}{|l|}{ Sustainable Site Planning- $12 \%$} \\
\hline Criterion 1: Green Infrastructure & 5 & $2+1 *$ & & 2 \\
\hline Criterion 2: Low-Impact Design Strategies & 5 & & & 5 \\
\hline Criterion 3: Design to Mitigate UHIE & 2 & & & 2 \\
\hline \multicolumn{5}{|l|}{ Construction Management- $4 \%$} \\
\hline Criterion 4: Air and Soil Pollution Control & 1 & & & 1 \\
\hline Criterion 5: Topsoil Preservation & 1 & & & 1 \\
\hline $\begin{array}{l}\text { Criterion 6: Construction Management } \\
\text { Practices }\end{array}$ & 2 & & & 2 \\
\hline \multicolumn{5}{|l|}{ Energy Optimization-18\% } \\
\hline Criterion 7: Energy Optimization & 12 & & & 12 \\
\hline Criterion 8: Renewable Energy Utilization & 5 & & & 5 \\
\hline Criterion 9: Low ODP and GWP Materials & 1 & & & 1 \\
\hline \multicolumn{5}{|l|}{ Occupant Comfort- $12 \%$} \\
\hline Criterion 10: Visual Comfort & 4 & 4 & & \\
\hline Criterion 11: Thermal and Acoustic Comfort & 2 & 2 & & \\
\hline Criterion 12: Indoor Air Quality & 6 & 6 & & \\
\hline \multicolumn{5}{|l|}{ Water Management- $16 \%$} \\
\hline Criterion 13: Water Demand Reduction & 3 & & & 3 \\
\hline Criterion 14: Wastewater Treatment & 3 & & & 3 \\
\hline Criterion 15: Rainwater Management & 5 & & & 5 \\
\hline
\end{tabular}




\begin{tabular}{|c|c|c|c|c|}
\hline \multirow[t]{2}{*}{ GRIHA } & \multirow[t]{2}{*}{ Maximum Points } & \multicolumn{3}{|c|}{ Dimension of Sustainability } \\
\hline & & Social & Economic & Environment \\
\hline $\begin{array}{l}\text { Criterion 16: Water Quality and } \\
\text { Self-sufficiency }\end{array}$ & 5 & & & 5 \\
\hline \multicolumn{5}{|l|}{ Solid Waste Management- $6 \%$} \\
\hline Waste Management-Post Occupancy & 4 & & & 4 \\
\hline Organic Waste Treatment On-site & 2 & & & 2 \\
\hline \multicolumn{5}{|l|}{ Sustainable Building Mateials- $12 \%$} \\
\hline $\begin{array}{l}\text { Criterion 19: Utilization of Alternative } \\
\text { Materials in Building }\end{array}$ & 5 & & & 5 \\
\hline $\begin{array}{l}\text { Criterion 20: Reduction in GWP through Life } \\
\text { Cycle Assessment }\end{array}$ & 5 & & & 5 \\
\hline $\begin{array}{l}\text { Criterion 21: Alternative Materials for } \\
\text { External Site Development }\end{array}$ & 2 & & & 2 \\
\hline \multicolumn{5}{|l|}{ Life Cycle Costing-5\% } \\
\hline Life Cycle Costing Analysis & 5 & & 5 & \\
\hline \multicolumn{5}{|l|}{ Socio-Economic Strategies- $8 \%$} \\
\hline $\begin{array}{l}\text { Criterion 23: Safety and Sanitation for } \\
\text { Construction Workers }\end{array}$ & 1 & 1 & & \\
\hline Criterion 24: Universal Accessibility & 2 & 2 & & \\
\hline $\begin{array}{c}\text { Criterion 25: Dedicated Facilities for Service } \\
\text { Staff }\end{array}$ & 2 & 2 & & \\
\hline Criterion 26: Positive Social Impact & 4 & 4 & & \\
\hline \multicolumn{5}{|l|}{ Performance Metering and Monitoring-7\% } \\
\hline $\begin{array}{l}\text { Criterion 27: Commissioning for Final } \\
\text { Rating }\end{array}$ & 0 & & & 0 \\
\hline $\begin{array}{c}\text { Criterion 28: Smart Metering and } \\
\text { Monitoring }\end{array}$ & 6 & & & 6 \\
\hline $\begin{array}{c}\text { Criterion 29: Operation and Maintenance } \\
\text { Protocol }\end{array}$ & 0 & & & 0 \\
\hline Total & 100 & & & \\
\hline \multicolumn{5}{|l|}{ Innovation } \\
\hline Criterion 30: Innovation & 5 & & & \\
\hline Grand Total & \multicolumn{4}{|c|}{$100+5=105$} \\
\hline
\end{tabular}

Percentile thresholds for achieving stars in GRIHA v.2019.

\begin{tabular}{cc}
\hline Percentile Threshold & Achievable Stars as per GRIHA v. 2019 \\
\hline $25-40$ & ${ }^{* *}$ \\
\hline $41-55$ & ${ }^{* * *}$ \\
\hline $56-70$ & ${ }^{* * * *}$ \\
\hline $71-85$ & $* * * * *$ \\
\hline 86 and more &
\end{tabular}

\section{IGBC Green New Buildings Rating System.}

\begin{tabular}{|c|c|c|c|c|c|}
\hline \multirow[t]{2}{*}{ IGBC } & \multicolumn{2}{|c|}{ Maximum Points } & \multicolumn{3}{|c|}{ Dimension of Sustainability } \\
\hline & $\begin{array}{l}\text { Owner-occupied } \\
\text { Buildings }\end{array}$ & $\begin{array}{l}\text { Tenant Occupied } \\
\text { Buildings }\end{array}$ & Social & Economic & Environment \\
\hline $\begin{array}{c}\text { Sustainable Architecture } \\
\text { and Design }\end{array}$ & 5 & & & & \\
\hline $\begin{array}{l}\text { Integrated Design } \\
\text { Approach }\end{array}$ & 1 & 1 & 1 & & \\
\hline Site Preservation & 2 & 2 & & & 2 \\
\hline Passive Architecture & 2 & 2 & & & 2 \\
\hline $\begin{array}{l}\text { Site Selection and } \\
\text { Planning }\end{array}$ & 14 & & & & \\
\hline
\end{tabular}




\begin{tabular}{|c|c|c|c|c|c|}
\hline \multirow[t]{2}{*}{ IGBC } & \multicolumn{2}{|c|}{ Maximum Points } & \multicolumn{3}{|c|}{ Dimension of Sustainability } \\
\hline & $\begin{array}{l}\text { Owner-occupied } \\
\text { Buildings }\end{array}$ & $\begin{array}{l}\text { Tenant Occupied } \\
\text { Buildings }\end{array}$ & Social & Economic & Environment \\
\hline Local Building Regulations & Required & Required & & & \\
\hline Soil Erosion Control & Required & Required & & & \\
\hline Basic Amenities & 1 & 1 & 1 & & $*$ \\
\hline Proximity to Public Transport & 1 & 1 & 1 & & \\
\hline Low-emitting Vehicles & 1 & 1 & & & 1 \\
\hline $\begin{array}{c}\text { Natural Topography or } \\
\text { Vegetation }\end{array}$ & 2 & 2 & & & 2 \\
\hline $\begin{array}{c}\text { Preservation or } \\
\text { Transplantation of Trees }\end{array}$ & 1 & 1 & & & 1 \\
\hline $\begin{array}{l}\text { Heat Island Reduction, } \\
\text { Non-roof }\end{array}$ & 2 & 2 & & & 2 \\
\hline Heat Island Reduction, Roof & 2 & 2 & & & 2 \\
\hline $\begin{array}{l}\text { Outdoor Light Pollution } \\
\text { Reduction }\end{array}$ & 1 & 1 & & & 1 \\
\hline Universal Design & 1 & 1 & 1 & & \\
\hline $\begin{array}{l}\text { Basic Facilities for } \\
\text { Construction Workforce }\end{array}$ & 1 & 1 & 1 & & \\
\hline Green Building Guidelines & 1 & 1 & 1 & & 1 \\
\hline Water Conservation & 18 & & & & \\
\hline $\begin{array}{c}\text { Rainwater Harvesting, Roof \& } \\
\text { Non-roof }\end{array}$ & Required & Required & & & \\
\hline $\begin{array}{l}\text { Water Efficient Plumbing } \\
\text { Fixtures }\end{array}$ & Required & Required & & & \\
\hline Landscape Design & 2 & 2 & & & 2 \\
\hline $\begin{array}{l}\text { Management of Irrigation } \\
\text { Systems }\end{array}$ & 1 & 1 & & & 1 \\
\hline $\begin{array}{l}\text { Rainwater Harvesting, Roof \& } \\
\text { Non-roof }\end{array}$ & 4 & 4 & & & 4 \\
\hline $\begin{array}{l}\text { Water Efficient Plumbing } \\
\text { Fixtures }\end{array}$ & 5 & 5 & & & 5 \\
\hline $\begin{array}{l}\text { Wastewater Treatment and } \\
\text { Reuse }\end{array}$ & 5 & 5 & & & 5 \\
\hline Water Metering & 1 & 2 & & & 1 \\
\hline Energy Efficiency & 28 & & & & \\
\hline Ozone Depleting Substances & Required & Required & & & \\
\hline Minimum Energy Efficiency & Required & Required & & & \\
\hline $\begin{array}{l}\text { Commissioning Plan for } \\
\text { Building Required Equipment } \\
\text { \& Systems }\end{array}$ & Required & Required & & & \\
\hline Eco-friendly Refrigerants & 1 & 1 & & & 1 \\
\hline Enhanced Energy Efficiency & 15 & 15 & & & 15 \\
\hline On-site Renewable Energy & 6 & 6 & & & 6 \\
\hline Off-site Renewable Energy & 2 & 2 & & & 2 \\
\hline $\begin{array}{c}\text { Commissioning, } \\
\text { Post-installation of Equipment } \\
\text { \& Systems }\end{array}$ & 2 & 2 & & & 2 \\
\hline $\begin{array}{l}\text { Energy Metering and } \\
\text { Management }\end{array}$ & 2 & 2 & & & 2 \\
\hline $\begin{array}{l}\text { Building Materials and } \\
\text { Resources } \\
\end{array}$ & 16 & & & & \\
\hline $\begin{array}{l}\text { Segregation of Waste, } \\
\text { Post-occupancy }\end{array}$ & Required & Required & & & \\
\hline Sustainable Building Materials & 8 & $8(1+2+2+2+2)$ & & $*$ & \\
\hline $\begin{array}{l}\text { Organic Waste Management, } \\
\text { Post-occupancy }\end{array}$ & 2 & 2 & & & 2 \\
\hline $\begin{array}{l}\text { Handling of Waste Materials, } \\
\text { During Construction }\end{array}$ & 1 & 1 & & & 1 \\
\hline
\end{tabular}




\begin{tabular}{|c|c|c|c|c|c|}
\hline \multirow[t]{2}{*}{ IGBC } & \multicolumn{2}{|c|}{ Maximum Points } & \multicolumn{3}{|c|}{ Dimension of Sustainability } \\
\hline & $\begin{array}{l}\text { Owner-occupied } \\
\text { Buildings }\end{array}$ & $\begin{array}{l}\text { Tenant Occupied } \\
\text { Buildings }\end{array}$ & Social & Economic & Environment \\
\hline $\begin{array}{c}\text { Use of Certified Green } \\
\text { Building Materials, Products \& } \\
\text { Equipment }\end{array}$ & 5 & 5 & & & 5 \\
\hline Indoor Environmental Quality & 12 & & & & \\
\hline $\begin{array}{l}\text { Minimum Fresh Air } \\
\text { Ventilation }\end{array}$ & Required & Required & & & \\
\hline Tobacco Smoke Control & Required & Required & & & \\
\hline CO2 Monitoring & 1 & 1 & 1 & & \\
\hline Daylighting & 2 & 2 & 2 & & \\
\hline Outdoor Views & 1 & 1 & 1 & & \\
\hline $\begin{array}{l}\text { Minimize Indoor and Outdoor } \\
\text { Pollutants }\end{array}$ & 1 & 1 & 1 & & \\
\hline Low-emitting materials & 3 & 3 & 3 & & \\
\hline Occupant Well-being Facilities & 1 & & & & \\
\hline $\begin{array}{l}\text { Indoor Air Quality Testing, } \\
\text { After Construction and Before } \\
\text { Occupancy }\end{array}$ & 2 & 2 & 2 & & \\
\hline $\begin{array}{l}\text { Indoor Air Quality } \\
\text { Management, During } \\
\text { Construction }\end{array}$ & 1 & 1 & 1 & & \\
\hline Innovation and Development & 7 & & & & \\
\hline Innovation in Design Process & 4 & 4 & & & \\
\hline $\begin{array}{l}\text { Optimization in Structural } \\
\text { Design }\end{array}$ & 1 & 1 & & & 1 \\
\hline $\begin{array}{c}\text { Waste Water Reuse, During } \\
\text { Construction }\end{array}$ & 1 & 1 & & & 1 \\
\hline IGBC Accredited Professional & 1 & 1 & 1 & & \\
\hline Total & & & & & \\
\hline
\end{tabular}

Percentile thresholds for different certification levels in IGBC Green New Buildings Rating System.

\begin{tabular}{cccc}
\hline Certification Level & $\begin{array}{c}\text { Owner-Occupied } \\
\text { Buildings }\end{array}$ & $\begin{array}{c}\text { Tenant-Occupied } \\
\text { Buildings }\end{array}$ & Recognition \\
\hline Certified & $40-49$ & $40-49$ & Best Practices \\
\hline Silver & $50-59$ & $50-59$ & Outstanding Performance \\
\hline Gold & $60-74$ & $60-74$ & National Excellence \\
\hline Platinum & $75-100$ & $75-100$ & Global Leadership \\
\hline
\end{tabular}

Green Star-Design \& As-Built, 2017.

\begin{tabular}{|c|c|c|c|c|}
\hline \multirow[t]{2}{*}{ Green Star } & \multirow{2}{*}{$\begin{array}{c}\text { Maximum Points } \\
\begin{array}{c}\text { Owner-Occupied } \\
\text { Buildings }\end{array}\end{array}$} & \multicolumn{3}{|c|}{ Dimension of Sustainability } \\
\hline & & Social & Economic & Environment \\
\hline MANAGEMENT & 14 & & & \\
\hline Green Star Accredited Professional & 1 & 1 & & \\
\hline Commissioning and Tuning & 4 & 4 & & \\
\hline Adaptation and Resilience & 2 & & & 2 \\
\hline Building Information & 1 & 1 & & \\
\hline Commitment to Performance & 2 & & & 2 \\
\hline Metering and Monitoring & 1 & & & 1 \\
\hline Responsible Construction Practices & 2 & 1 & & 1 \\
\hline Operational Waste & 1 & & & 1 \\
\hline INDOOR ENVIRONMENT QUALITY & 17 & & & \\
\hline Indoor Air Quality & 4 & 4 & & \\
\hline
\end{tabular}




\begin{tabular}{|c|c|c|c|c|}
\hline \multirow[t]{2}{*}{ Green Star } & \multirow{2}{*}{$\begin{array}{c}\text { Maximum Points } \\
\begin{array}{c}\text { Owner-Occupied } \\
\text { Buildings }\end{array}\end{array}$} & \multicolumn{3}{|c|}{ Dimension of Sustainability } \\
\hline & & Social & Economic & Environment \\
\hline Acoustic Comfort & 3 & 3 & & \\
\hline Lighting Comfort & 3 & 3 & & \\
\hline Visual Comfort & 3 & 3 & & \\
\hline Thermal Comfort & 2 & 2 & & \\
\hline Access to Fresh Food & 2 & 2 & & \\
\hline ENERGY & 22 & & & \\
\hline Greenhouse Gas Emissions & 20 & & & 20 \\
\hline Peak Electricity Demand Reduction & 2 & & & 2 \\
\hline TRANSPORT & 10 & & & \\
\hline Sustainable Transport & 10 & 5 & & 5 \\
\hline WATER & 12 & & & \\
\hline Potable Water & 12 & & & 12 \\
\hline MATERIALS & 14 & & & \\
\hline Life Cycle Impacts & 7 & & & 7 \\
\hline Responsible Building Materials & 3 & & & 3 \\
\hline Sustainable Product & 3 & & & 3 \\
\hline Construction and Demolition Waste & 1 & & & 1 \\
\hline LAND USE \& ECOLOGY & 6 & & & \\
\hline Ecological Value & 3 & & & 3 \\
\hline Sustainable Sites & 2 & & & 2 \\
\hline Heat Island Effect & 1 & & & 1 \\
\hline EMISSIONS & 5 & & & \\
\hline Stormwater & 2 & & & 2 \\
\hline Light Pollution & 1 & & & 1 \\
\hline Microbial Control & 1 & & & 1 \\
\hline Refrigerant Impacts & 1 & & & 1 \\
\hline Total & 100 & & & \\
\hline INNOVATION & 10 & & & \\
\hline Innovation & 10 & 5 & & 5 \\
\hline Grand Total & & & & \\
\hline
\end{tabular}

Percentile thresholds for different certification levels in Green Star-Design \& As-Built, 2017.

\begin{tabular}{ccc}
\hline Percentage of Available Points & Rating & Outcome \\
\hline$<10$ & No & Assessed \\
\hline $10-19$ & $*$ & Minimum practice \\
\hline $20-29$ & $* *$ & Average practice \\
\hline $30-44$ & $* * *$ & Good practice \\
\hline $45-59$ & $* * * *$ & Australian best practice \\
\hline $60-74$ & $* * * *$ & Australian excellence \\
\hline $75+$ & $* * * * *$ & World leadership
\end{tabular}


Green Mark for Non-Residential Building NRB:2015.

\begin{tabular}{|c|c|c|c|c|}
\hline \multirow[t]{2}{*}{ Green Mark } & \multirow[t]{2}{*}{ Maximum Points } & \multicolumn{3}{|c|}{ Dimension of Sustainability } \\
\hline & & Social & Economic & Environment \\
\hline \multicolumn{5}{|l|}{ Elective Requirements } \\
\hline \multicolumn{5}{|l|}{ Part 1-Climate Responsive Design } \\
\hline Climate Responsive Design & Prerequisite & & & \\
\hline Envelope and Roof Thermal Transfer & Prerequisite & & & \\
\hline Air Tightness and Leakage & Prerequisite & & & \\
\hline Bicycle Parking & Prerequisite & & & \\
\hline 1.1 Leadership & 10 & & & \\
\hline 1.1a Climatic \& Contextually Responsive Brief & 1 & & & 1 \\
\hline $\begin{array}{c}\text { 1.1b Integrative Design Process }{ }^{*} 4 \mathrm{D}, 5 \mathrm{D} \& 6 \mathrm{D} \\
\text { BIM (Advanced Green Efforts)) }\end{array}$ & $4(* 3)$ & $*^{* 1}$ & $*^{* 1}$ & $* 2$ \\
\hline 1.1c Environmental Credentials of Project Team & 2 & 2 & & \\
\hline 1.1d User Engagement & 3 & 3 & & \\
\hline 1.2 Urban Harmony & 10 points & & & \\
\hline 1.2a Sustainable Urbanism & Up to 5 points & & & \\
\hline $\begin{array}{l}\text { (i) Environmental Analysis ( }{ }^{*} \text { Creation of } \\
\text { possible new ecology and natural ecosystems } \\
\text { (Advanced Green Efforts)) }\end{array}$ & $2\left({ }^{*} 1\right)$ & & & $2\left({ }^{*} 1\right)$ \\
\hline (ii) Response to Site Context & 3 & 1 & 1 & 1 \\
\hline (iii) Urban Heat Island (UHI) Mitigation & 1 & & & 1 \\
\hline (iv) Green Transport & 1.5 & 1.5 & & \\
\hline 1.2b Integrated Landscape and Waterscape & Up to 5 points & & & \\
\hline $\begin{array}{l}\text { Green Plot (i) Ratio (GnPR) }\left({ }^{*} \mathrm{GnPR} \geq 5.0\right. \\
\text { (Advanced Green Efforts)) }\end{array}$ & $3(* 1)$ & & & $3\left({ }^{*} 1\right)$ \\
\hline (ii) Tree Conservation & 1 & & & 1 \\
\hline (iii) Sustainable Landscape Management & 1.5 & & & 1.5 \\
\hline (iv) Sustainable Storm Water Management & 1 & & & 1 \\
\hline 1.3 Tropical & 10 points & & & \\
\hline $\begin{array}{l}\text { 1.3a Tropical Façade Performance } \\
\text { Low heat gain façade (Advanced Green Efforts) } \\
\text { Greenery on the East and West Façade } \\
\text { (Advanced Green Efforts) } \\
\text { Thermal Bridging (Advanced Green Efforts) }\end{array}$ & $3\left({ }^{*} 1,1,1\right)$ & $3\left({ }^{*} 1,1,1\right)$ & & \\
\hline 1.3b Internal Spatial Organisation & 3 & 3 & & \\
\hline $\begin{array}{l}\text { 1.3c Ventilation Performance (*Wind Driven } \\
\text { Rain Simulation (Advanced Green Efforts)) }\end{array}$ & $4\left({ }^{*} 1\right)$ & $4\left({ }^{*} 1\right)$ & & \\
\hline Part 2-Building Energy Performance & 22 points & & & \\
\hline $\begin{array}{l}\text { Air Conditioning Total System and } \\
\text { Component Efficiency }\end{array}$ & Prerequisite & & & \\
\hline Lighting Efficiency and Controls & Prerequisite & & & \\
\hline Vertical Transportation Efficiency & Prerequisite & & & \\
\hline \multicolumn{5}{|l|}{ 2.1 Energy Efficiency } \\
\hline \multicolumn{5}{|l|}{$\begin{array}{l}\text { Option 1: Energy Performance Points } \\
\text { Calculator }\end{array}$} \\
\hline 2.1a Air Conditioning Total System Efficiency & 5 & & & 5 \\
\hline 2.1b Lighting System Efficiency & 3 & & & 3 \\
\hline 2.1c Carpark System Efficiency & 2 & & & 2 \\
\hline 2.1d Receptacle Efficiency & 1 & & & 1 \\
\hline $\begin{array}{l}\text { 2.1e Building Energy (*Further Improvement } \\
\text { in Design Energy Consumption (Advanced } \\
\text { Green Efforts) }\end{array}$ & $11\left({ }^{*} 2\right)$ & & & $11(* 2)$ \\
\hline \multicolumn{5}{|l|}{ Option 2: Performance-Based Computation } \\
\hline $\begin{array}{l}\text { 2.1f Space Conditioning Performance } \\
\left({ }^{*} \text { Efficient space conditioning energy design }\right. \\
\text { (Advanced Green Efforts)) }\end{array}$ & $10\left({ }^{*} 1\right)$ & & & $10\left({ }^{*} 1\right)$ \\
\hline
\end{tabular}




\begin{tabular}{|c|c|c|c|}
\hline \multirow[t]{2}{*}{ Green Mark } & \multirow[t]{2}{*}{ Maximum Points } & \multicolumn{2}{|c|}{ Dimension of Sustainability } \\
\hline & & Economic & Environment \\
\hline $\begin{array}{l}\text { 2.1g Lighting Performance (*Efficient lighting } \\
\text { design (Advanced Green Efforts)) }\end{array}$ & $6\left({ }^{*} 1\right)$ & & $6\left({ }^{*} 1\right)$ \\
\hline $\begin{array}{l}\text { 2.1h Building System Performance } \\
\left({ }^{*} \text { Additional Energy-Efficient Practices and }\right. \\
\text { Features (Advanced Green Efforts)) }\end{array}$ & $6\left({ }^{*} 2\right)$ & & $6(* 2)$ \\
\hline 2.2 Renewable Energy & 8 points & & \\
\hline 2.2a Solar Energy Feasibility Study & 0.5 & & 0.5 \\
\hline 2.2b Solar Ready Roof & 1.5 & & 1.5 \\
\hline $\begin{array}{l}\text { 2.2c Adoption of Renewable Energy (*Further } \\
\text { Electricity Replacement by Renewables } \\
\text { (Advanced Green Efforts)) }\end{array}$ & $6(* 5)$ & & $6(* 5)$ \\
\hline \multicolumn{4}{|l|}{ Part 3-Resource Stewardship } \\
\hline Water Efficient Fittings & Prerequisite & & \\
\hline 3.1 Water & 8 points & & \\
\hline 3.1a Water Efficient Systems & 3 & & 3 \\
\hline (i) Landscape irrigation & 1 & & 1 \\
\hline $\begin{array}{l}\text { (ii) Water Consumption of Cooling Towers } \\
\text { (*Better Water Efficient Fittings (Advanced } \\
\text { Green Efforts) }\end{array}$ & 2 & & 2 \\
\hline 3.1b Water Monitoring & 2 & & 2 \\
\hline (i) Water Monitoring and Leak Detection & 1 & & 1 \\
\hline (ii) Water Usage Portal and Dashboard & 1 & & 1 \\
\hline 3.1c Alternative Water Sources & 3 & & 3 \\
\hline 3.2 Materials & 18 points & & \\
\hline 3.2a Sustainable Construction & 8 & & 8 \\
\hline (i) Conservation and Resource Recovery & 1 & & 1 \\
\hline $\begin{array}{l}\text { (ii) Resource Efficient Building Design (* Use of } \\
\text { BIM to calculate CUI (Advanced Green } \\
\text { Efforts)) }\end{array}$ & $4\left({ }^{*} 1\right)$ & & $4\left({ }^{*} 1\right)$ \\
\hline $\begin{array}{l}\text { (iii) Low Carbon Concrete }(* \text { Use of Advanced } \\
\text { Green Materials (Advanced Green Efforts)) }\end{array}$ & $3\left({ }^{*} 1\right)$ & & $3\left({ }^{*} 1\right)$ \\
\hline $\begin{array}{l}\text { 3.2b Embodied Carbon } \\
\text { (*Provide Own Emission Factors with Source } \\
\text { Justification (Advanced Green Efforts), } \\
\text { Compute the Carbon Footprint of the Entire } \\
\text { Development (Advanced Green Efforts)) }\end{array}$ & $2\left({ }^{*} 1,1\right)$ & & $2\left({ }^{*} 1,1\right)$ \\
\hline 3.2c Sustainable Products & 8 points & & \\
\hline (i) Functional System & 8 & & 8 \\
\hline $\begin{array}{c}\text { (ii) Singular Sustainable Products outside of } \\
\text { Functional Systems ( }{ }^{*} \text { Sustainable Products } \\
\text { with Higher Environmental Credentials } \\
\text { (Advanced Green Efforts)) }\end{array}$ & $2\left({ }^{*} 2\right)$ & & $2(* 2)$ \\
\hline 3.3 Waste & 4 points & & \\
\hline $\begin{array}{l}\text { 3.3a Environmental Construction Management } \\
\text { Plan }\end{array}$ & 1 & & 1 \\
\hline 3.3b Operational Waste Management & 3 & & 3 \\
\hline \multicolumn{4}{|l|}{ Part 4-Smart \& Healthy Building } \\
\hline Thermal Comfort & Prerequisite & & \\
\hline Minimum Ventilation Rate & Prerequisite & & \\
\hline Filtration Media for Times of Pollution & Prerequisite & & \\
\hline Low Volatile Organic Compound (VOC) Paints & Prerequisite & & \\
\hline Refrigerants & Prerequisite & & \\
\hline Sound Level & Prerequisite & & \\
\hline \multicolumn{4}{|l|}{$\begin{array}{l}\text { Permanent Instrumentation for the } \\
\text { Measurement and Verification of Chilled Water } \\
\text { Air-Conditioning Systems }\end{array}$} \\
\hline Electrical Sub-Metering \& Monitoring & Prerequisite & & \\
\hline
\end{tabular}




\begin{tabular}{|c|c|c|c|c|}
\hline \multirow[t]{2}{*}{ Green Mark } & \multirow[t]{2}{*}{ Maximum Points } & \multicolumn{3}{|c|}{ Dimension of Sustainability } \\
\hline & & Social & Economic & Environment \\
\hline 4.1 Indoor Air Quality & 10 points & & & \\
\hline 4.1a Occupant Comfort & 2 & 2 & & \\
\hline (i) Indoor Air Quality (IAQ) Surveillance Audit & 1 & 1 & & \\
\hline (ii) Post Occupancy Evaluation & 0.5 & 0.5 & & \\
\hline $\begin{array}{l}\text { (iii) Indoor Air Quality Display (* Indoor Air } \\
\text { Quality Trending (Advanced Green Efforts) }\end{array}$ & 0.5 & 0.5 & & \\
\hline 4.1b Outdoor Air & 3 points & 3 points & & \\
\hline (i) Ventilation Rates & 1.5 & 1.5 & & \\
\hline (ii) Enhanced Filtration Media & 1 & 1 & & \\
\hline (iii) Dedicated Outdoor Air System & 0.5 & 0.5 & & \\
\hline 4.1c Indoor Contaminants & 5 points & 5 points & & \\
\hline (i) Local Exhaust and Air Purging System & 2 & 2 & & \\
\hline $\begin{array}{l}\text { (ii) Ultraviolet Germicidal Irradiation (UVGI) } \\
\text { System }\end{array}$ & 0.5 & 0.5 & & \\
\hline $\begin{array}{l}\text { (iii) More Stringent VOC Limits for Interior } \\
\text { Fittings and Finishes }\end{array}$ & 2 & 2 & & \\
\hline $\begin{array}{l}\text { (iv)Use of Persistent Bio-cumulative and Toxic } \\
\text { (PBT) free lighting (*Zero ODP Refrigerants } \\
\text { with Low Global Warming Potential } \\
\text { (Advanced Green Efforts)) }\end{array}$ & $0.5\left({ }^{*} 1\right)$ & $0.5(* 1)$ & & \\
\hline 4.2 Spatial Quality & 10 points & 10 points & & \\
\hline 4.2a Lighting & Up to 6 points & Up to 6 points & & \\
\hline (i) Effective daylighting for common areas & 2 & 2 & & \\
\hline (ii) Effective daylighting for occupied spaces & 4 & 4 & & \\
\hline (iii) Quality of Artificial Lighting & 1 & 1 & & \\
\hline $4.2 \mathrm{~b}$ Acoustics & 2 & 2 & & \\
\hline (i) Sound Transmission Reduction & 0.5 & 0.5 & & \\
\hline (ii)Acoustic Report & 1.5 & 1.5 & & \\
\hline 4.2c Wellbeing & Up to 2 points & Up to 2 points & & \\
\hline (i) Biophilic Design & 3 & & & 3 \\
\hline (ii) Universal Design (UD) Mark & 1 & 1 & & \\
\hline 4.3 Smart Building Operations & 10 points & & & \\
\hline 4.3a Energy Monitoring & 3 & & & 3 \\
\hline (i) Energy Portal and Dashboard & 2 & & & 2 \\
\hline $\begin{array}{l}\text { (ii) BAS and Controllers with Open Protocol (* } \\
\text { Permanent M\&V for VRF Systems (Advanced } \\
\text { Green Effort), Permanent M\&V for Hot Water } \\
\text { systems (Advanced Green Efforts)) }\end{array}$ & $1(* 2,1)$ & & & $1\left({ }^{*} 2,1\right)$ \\
\hline 4.3b Demand Control & 3 & & 3 & \\
\hline (i) ACMV Demand Control & 2 & & 2 & \\
\hline (ii) Lighting Demand Control & 1 & & 1 & \\
\hline (iii) Carpark Guidance System & 0.5 & 0.5 & & \\
\hline 4.3c Integration and Analytics & 3 & & & \\
\hline (i) Basic Integration and Analytics & $0.5 /$ feature & & & $0.5 /$ feature \\
\hline $\begin{array}{l}\text { (ii) Advanced Integration and Analytics (* } \\
\text { Additional Advanced Integration and } \\
\text { Analytical Features (Advanced Green Effort)) }\end{array}$ & $1 /$ feature $\left({ }^{*} 1\right)$ & & & $\begin{array}{l}1 / \text { feature } \\
\quad\left({ }^{*} 1\right)\end{array}$ \\
\hline 4.3d System Handover and Documentation & 1 & 1 & & \\
\hline $\begin{array}{l}\text { Expanded Post Occupancy Performance } \\
\text { Verification by a 3rd Party (Advanced Green } \\
\text { Effort) }\end{array}$ & 2 & 2 & & \\
\hline $\begin{array}{l}\text { Energy Performance Contracting (Advanced } \\
\text { Green Effort) }\end{array}$ & 1 & & & 1 \\
\hline Part 5-Advanced Green Efforts & 20 points & & & \\
\hline 5.1 Enhanced Performance & Up to 15 points & & & 15 \\
\hline
\end{tabular}




\begin{tabular}{|c|c|c|c|c|}
\hline \multirow[t]{2}{*}{ Green Mark } & \multirow[t]{2}{*}{ Maximum Points } & \multicolumn{3}{|c|}{ Dimension of Sustainability } \\
\hline & & Social & Economic & Environment \\
\hline 5.2 Complementary Certifications & 1 & & & 1 \\
\hline 5.3 Demonstrating Cost Effective Design & 1 & & 1 & \\
\hline 5.4 Social Benefits & 2 & 2 & & \\
\hline Annexes for specialized buildings & 10 to 15 points & & & \\
\hline $\begin{array}{l}\text { Annex 1: Energy Efficiency Features for } \\
\text { Specialised Building [Hawker Centres] }\end{array}$ & 15 & & & 15 \\
\hline $\begin{array}{l}\text { Annex 2: Energy Efficiency Features for } \\
\text { Specialised Building Healthcare Facilities] }\end{array}$ & 10 & & & 10 \\
\hline $\begin{array}{l}\text { Annex 3: Energy Efficiency Features for } \\
\text { Specialised Building [Laboratories] }\end{array}$ & 10 & & & 10 \\
\hline $\begin{array}{l}\text { Annex 4: Energy Efficiency Features for } \\
\text { Specialised Building [Schools] }\end{array}$ & 10 & & & 10 \\
\hline Total & & $150-$ & & \\
\hline
\end{tabular}

Percentile thresholds for different certification levels in IGBC Green New Buildings Rating System.

\begin{tabular}{cc}
\hline Green Mark Rating & Green Mark Score (Percentage Point Scored) \\
\hline Green Mark Platinum & 70 and above \\
\hline Green Mark Gold PLUS & 60 to $<70$ \\
\hline Green Mark Gold & $>50$ to $<60$ \\
\hline Green Mark Certified & Compliance with all pre-requisite requirement \\
\hline
\end{tabular}

\section{DGNB System criteria set-New Construction Building.}

\begin{tabular}{|c|c|c|c|c|}
\hline \multirow[t]{2}{*}{ DGNB } & \multirow[t]{2}{*}{ Maximum Points } & \multicolumn{3}{|c|}{ Dimension of Sustainability } \\
\hline & & Social & Economic & Environment \\
\hline Environmental Quality & $22.50 \%$ & & & \\
\hline Building life cycle assessment & & & & 9.5 \\
\hline Local environmental impact & & & & 4.7 \\
\hline sustainable resource extraction & & & & 2.4 \\
\hline $\begin{array}{l}\text { Potable water demand and } \\
\text { wastewater volume }\end{array}$ & & & & 2.4 \\
\hline Land use & & & & 2.4 \\
\hline Bio-diversity at site & & & & 1.2 \\
\hline Economic Quality & $22.50 \%$ & & & \\
\hline Life cycle costing & & & 10 & \\
\hline Flexibility and adaptability & & & 7.5 & \\
\hline Commercial viability & & & 5.0 & \\
\hline $\begin{array}{l}\text { Socio-Cultural and functional } \\
\text { quality }\end{array}$ & $22.50 \%$ & & & \\
\hline Thermal comfort & & 4.1 & & \\
\hline Indoor air quality & & 5.1 & & \\
\hline Acoustic comfort & & 2.0 & & \\
\hline Visual comfort & & 3.1 & & \\
\hline User control & & 2.0 & & \\
\hline $\begin{array}{l}\text { Quality of indoor and outdoor } \\
\text { spaces }\end{array}$ & & 2.0 & & \\
\hline Safety and security & & 1.0 & & \\
\hline Design for all & & 3.1 & & \\
\hline Technical Quality & $15 \%$ & & & \\
\hline Sound insulation & & 1.15 & & \\
\hline
\end{tabular}




\begin{tabular}{|c|c|c|c|c|}
\hline \multirow[t]{2}{*}{ DGNB } & \multirow[t]{2}{*}{ Maximum Points } & \multicolumn{3}{|c|}{ Dimension of Sustainability } \\
\hline & & Social & Economic & Environment \\
\hline Quality of the building envelope & & & & 2.96 \\
\hline $\begin{array}{l}\text { Use and integration of building } \\
\text { technology }\end{array}$ & & & 1.23 & 1.23 \\
\hline $\begin{array}{l}\text { Ease of cleaning building } \\
\text { components }\end{array}$ & & & 0.83 & 0.83 \\
\hline Ease of recovery and recycling & & & 1.63 & 1.63 \\
\hline Emissions control & & 0.71 & & 0.71 \\
\hline Mobility infrastructure & & 0.82 & 0.82 & 0.82 \\
\hline Process Quality & $12.50 \%$ & & & \\
\hline Comprehensive project brief & & 1.6 & & \\
\hline $\begin{array}{l}\text { Sustainability aspects in the tender } \\
\text { phase }\end{array}$ & & & & 1.6 \\
\hline $\begin{array}{c}\text { Documentation for sustainable } \\
\text { management }\end{array}$ & & & 1.1 & \\
\hline $\begin{array}{l}\text { Procedure for urban and design } \\
\text { planning }\end{array}$ & & 0.8 & & 0.8 \\
\hline $\begin{array}{l}\text { Construction site/construction } \\
\text { process }\end{array}$ & & 0.8 & & 0.8 \\
\hline $\begin{array}{l}\text { Quality assurance of the } \\
\text { construction }\end{array}$ & & 0.53 & 0.53 & 0.53 \\
\hline Systematic commissioning & & & & 1.6 \\
\hline User communication & & 0.55 & & 0.55 \\
\hline FM-compliant planning & & & & 0.5 \\
\hline Site Quality & $5 \%$ & & & \\
\hline Local environment & & 0.55 & & 0.55 \\
\hline Influence on the district & & & 1.1 & \\
\hline Transport access & & 0.36 & 0.36 & 0.36 \\
\hline Access to amenities & & 0.85 & & 0.85 \\
\hline Total & & & & \\
\hline
\end{tabular}

Classification of different certification levels as per DGNB System criteria set-New Construction Building.

\begin{tabular}{cc}
\hline Certification & Percentage Points \\
\hline DGNB Platinum & $65-80$ \\
\hline DGNB Gold & $50-65$ \\
\hline DGNB Silver & $35-50$ \\
\hline DGNB Bronze & $>35$ \\
\hline
\end{tabular}

CASBEE.

\begin{tabular}{|c|c|c|c|c|}
\hline \multirow[t]{2}{*}{ CASBEE } & \multirow[t]{2}{*}{ Maximum Points } & \multicolumn{3}{|c|}{ Dimension of Sustainability } \\
\hline & & Social & Economic & Environment \\
\hline Water Efficiency & 15 & & & \\
\hline Water leakage Detection & 3.6 & & & 3.6 \\
\hline Water use during construction & 1.8 & & & 1.8 \\
\hline Waste water management & 7.2 & & & 7.2 \\
\hline Sanitary used pipe & 2.4 & & & 2.4 \\
\hline Materials Resources & 10 & & & \\
\hline Regionally procured materials & 1.5 & 0.75 & 0.75 & \\
\hline Materials fabricated on site & 0.5 & & & 0.5 \\
\hline Use of readily renewable materials & 1.5 & & & 1.5 \\
\hline
\end{tabular}




\begin{tabular}{|c|c|c|c|c|}
\hline \multirow[t]{2}{*}{ CASBEE } & \multirow[t]{2}{*}{ Maximum Points } & \multicolumn{3}{|c|}{ Dimension of Sustainability } \\
\hline & & Social & Economic & Environment \\
\hline Use of salvaged material & 1.5 & & 0.75 & 0.75 \\
\hline Use of recycled material & 2 & & 1.0 & 1.0 \\
\hline Use of lightweight materials & 0.5 & & & 0.5 \\
\hline Use of higher durability materials & 0.5 & & & 0.5 \\
\hline Use of prefabricated elements & 1.5 & & 0.75 & 0.75 \\
\hline $\begin{array}{l}\text { Life cycle cost analysis of materials } \\
\text { in the project }\end{array}$ & 0.5 & & 0.5 & \\
\hline Indoor Environmental Quality & 10 & 10 & & \\
\hline $\begin{array}{c}\text { Sustainable Site, Accessibility and } \\
\text { Ecology }\end{array}$ & 15 & 7.5 & & 7.5 \\
\hline Desert Area Development & 1.5 & & & 1.5 \\
\hline Informal Area Development & 1.5 & 1.5 & & \\
\hline Brownfield site development & 1.5 & & & 1.5 \\
\hline $\begin{array}{l}\text { Compatibility with the national } \\
\text { development plan }\end{array}$ & 1.5 & & & \\
\hline Transport infrastructure connection & 1.5 & 1.5 & & \\
\hline Catering for remote site & 1.5 & 1.5 & & \\
\hline Alternative methods of transport & 1.5 & & & 1.5 \\
\hline Protection of habitat & 1.5 & & & 1.5 \\
\hline Energy Efficiency & 25 & & & \\
\hline Passive External Heat Gain Loss & 7.5 & & & 7.5 \\
\hline Reduction & 3.5 & & & 3.5 \\
\hline Energy Efficient Appliances & 1.5 & & & 1.5 \\
\hline Vertical Transportation Systems & 1.5 & & & 1.5 \\
\hline Peak Load Reductions & 3 & & 1.5 & 1.5 \\
\hline Renewable Energy Sources & 5 & & & 5 \\
\hline Environmental Impact & 2 & & & 2 \\
\hline Energy and Carbon Inventories & 1 & & & 1 \\
\hline Management & 10 & & & \\
\hline $\begin{array}{l}\text { Providing Containers for site } \\
\text { materials waste }\end{array}$ & 1 & & & 1 \\
\hline Control of emissions and pollutants & 1 & & & 1 \\
\hline Waste recycling workers on site & 0.5 & & & 0.5 \\
\hline $\begin{array}{l}\text { Providing Identified and separated } \\
\text { storage areas }\end{array}$ & 1 & & & 1 \\
\hline Project Waste Management Plan & 0.5 & & & 0.5 \\
\hline $\begin{array}{l}\text { Engaging a company specialized in } \\
\text { recycling }\end{array}$ & 1 & 1 & & \\
\hline $\begin{array}{l}\text { Protecting water sources from } \\
\text { pollution }\end{array}$ & 1 & & & 1 \\
\hline Waste from mixing equipment & 1 & & & 1 \\
\hline Total & & & & \\
\hline
\end{tabular}

Classification of different certification levels as per CASBEE.

\begin{tabular}{|c|c|c|c|c|}
\hline Ranks & Valuation & BEE Value & Indication & \\
\hline $\mathrm{s}$ & Excellent & $\begin{array}{c}\mathrm{BEE}=3.0 \text { or more and } \mathrm{Q}= \\
50 \text { or more }\end{array}$ & $* * * * *$ & \\
\hline A & Very Good & $\begin{aligned} & \mathrm{BEE}=1.5-3.0 \\
\mathrm{BEE}= & 3.0 \text { or more and } \mathrm{Q} \text { is } \\
& \text { less than } 50\end{aligned}$ & $* * * *$ & \\
\hline $\mathrm{B}^{+}$ & Good & $\mathrm{BEE}=1.0-1.5$ & $* * *$ & \\
\hline $\mathrm{B}^{-}$ & Fairly Poor & $\mathrm{BEE}=0.5-1.5$ & ** & \\
\hline $\mathrm{C}$ & Poor & BEE is less than 0.5 & * & 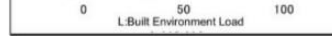 \\
\hline
\end{tabular}


BREEAM International New Construction 2016.

\begin{tabular}{|c|c|c|c|c|}
\hline \multirow[t]{2}{*}{ BREEAM } & \multirow[t]{2}{*}{ Maximum Points } & \multicolumn{3}{|c|}{ Dimension of Sustainability } \\
\hline & & Social & Economic & Environment \\
\hline Management & 20 & & & \\
\hline Project brief and design & $(2+2)$ & 4 & & \\
\hline Life cycle cost and service life planning & $(2+1+1)$ & & 4 & \\
\hline Responsible construction practices & $(1+1+2+2)$ & 3 & & 3 \\
\hline Commissioning and handover & $(1+1+1+1)$ & $*$ & 4 & \\
\hline Aftercare & $(1+1+1)$ & 2 & & $1 *$ \\
\hline Health and wellbeing & 22 & & & \\
\hline Visual comfort & 6 & 6 & & \\
\hline Indoor air quality & 5 & 5 & & \\
\hline Safe containment in laboratories & 2 & 1 & & 1 \\
\hline Thermal comfort & 3 & 3 & & \\
\hline Acoustic performance & 4 & 4 & & \\
\hline Accessibility & 2 & 2 & & \\
\hline Hazards & 1 & 0.5 & 0.5 & \\
\hline Private space & 1 & 1 & & \\
\hline Water quality & 1 & 1 & & * \\
\hline Energy & 35 & & & \\
\hline $\begin{array}{c}\text { Reduction of energy use and carbon } \\
\text { emissions }\end{array}$ & 15 & & & 15 \\
\hline Energy monitoring & 2 & & & 2 \\
\hline External lighting & 1 & & & 1 \\
\hline Low carbon design & 3 & & & 3 \\
\hline Energy-efficient cold storage & 3 & & & 3 \\
\hline Energy-efficient transport systems & 3 & & & 3 \\
\hline Energy-efficient laboratory systems & 5 & & & 5 \\
\hline Energy-efficient equipment & 2 & & & 2 \\
\hline Drying space & 1 & & & 1 \\
\hline Transport & 13 & & & \\
\hline Public transport accessibility & 5 & 1.67 & 1.67 & 1.67 \\
\hline Proximity to amenities & 2 & 0.67 & 0.67 & 0.67 \\
\hline Alternative modes of transport & 2 & & & 2 \\
\hline Maximum car parking capacity & 2 & & & 2 \\
\hline Travel plan & 1 & 0.33 & 0.33 & 0.33 \\
\hline Home office & 1 & 0.33 & 0.33 & 0.33 \\
\hline Water & 10 & & & \\
\hline Water consumption & 5 & & * & 5 \\
\hline Water monitoring & 1 & & * & 1 \\
\hline Water leak detection & 3 & & * & 3 \\
\hline Water-efficient equipment & 1 & & * & 1 \\
\hline Materials & 12 & & & \\
\hline Life cycle impacts & 6 & & & 6 \\
\hline $\begin{array}{l}\text { Hard landscaping and boundary } \\
\text { protection }\end{array}$ & $\mathrm{N} / \mathrm{A}$ & & & \\
\hline Responsible sourcing of materials & 4 & * & * & 4 \\
\hline Insulation & $\mathrm{N} / \mathrm{A}$ & & & \\
\hline Designing for durability and resilience & 1 & * & 0.5 & 0.5 \\
\hline Material efficiency & 1 & & 0.5 & 0.5 \\
\hline Waste & 10 & & & \\
\hline Construction waste management & 3 & & 1.5 & 1.5 \\
\hline Recycled aggregates & 1 & & * & 1 \\
\hline
\end{tabular}




\begin{tabular}{|c|c|c|c|c|}
\hline \multirow[t]{2}{*}{ BREEAM } & \multirow[t]{2}{*}{ Maximum Points } & \multicolumn{3}{|c|}{ Dimension of Sustainability } \\
\hline & & Social & Economic & Environment \\
\hline Operational waste & 2 & & $*$ & 2 \\
\hline Speculative floor and ceiling finishes & 1 & * & * & 1 \\
\hline Adaptation to climate change & 1 & 0.33 & 0.33 & 0.33 \\
\hline Functional adaptability & 1 & 0.5 & 0.5 & \\
\hline Land Use and Ecology & 10 & & & \\
\hline Site selection & 3 & & & 3 \\
\hline $\begin{array}{l}\text { The ecological value of site and } \\
\text { protection of ecological features }\end{array}$ & 2 & & & 2 \\
\hline $\begin{array}{l}\text { Minimizing impact on existing site } \\
\text { ecology }\end{array}$ & $\mathrm{N} / \mathrm{A}$ & & & \\
\hline Enhancing site ecology & 3 & & & 3 \\
\hline Long term impact on biodiversity & 2 & & & 2 \\
\hline Pollution & 13 & & & \\
\hline Impact of refrigerants & 4 & & & 4 \\
\hline NOx emissions & 2 & * & & 2 \\
\hline Surface water run-off & 5 & & & 5 \\
\hline Reduction of night time light pollution & 1 & & & 1 \\
\hline Reduction of noise pollution & 1 & & & 1 \\
\hline Innovation & 10 & & & \\
\hline \multicolumn{5}{|l|}{ Innovation } \\
\hline Total & & & & \\
\hline
\end{tabular}

Classification of different certification levels as per BREEAM rating benchmarks.

\begin{tabular}{cc}
\hline BREEAM Rating & Percentage Score \\
\hline Outstanding & $\geq 85$ \\
\hline Excellent & $\geq 70$ \\
\hline Very good & $\geq 55$ \\
\hline Good & $\geq 45$ \\
\hline Pass & $\geq 30$ \\
\hline Unclassified & $<30$ \\
\hline
\end{tabular}

Green Globes for New Construction.

\begin{tabular}{|c|c|c|c|c|}
\hline \multirow[t]{2}{*}{ Green Globes } & \multirow[t]{2}{*}{ Maximum Points } & \multicolumn{3}{|c|}{ Dimension of Sustainability } \\
\hline & & Social & Economic & Environment \\
\hline Project Management & 50 & & & \\
\hline Integrated Design Process (IDP) & 9 & & & 9 \\
\hline $\begin{array}{l}\text { Environmental Management During } \\
\text { Construction }\end{array}$ & 12 & & & 12 \\
\hline Commissioning & 29 & & & 29 \\
\hline Site & 115 & & & \\
\hline Development Area & 30 & & & 30 \\
\hline Ecological Impacts & 32 & & & 32 \\
\hline Stormwater Management & 18 & & & 18 \\
\hline Landscaping & 28 & & & 28 \\
\hline Exterior Light Pollution & 7 & 7 & & \\
\hline Energy & 390 & & & \\
\hline Energy Performance & 100 & & & 100 \\
\hline Energy Demand & 35 & & * & 35 \\
\hline Metering, Measurement, and Verification & 12 & & * & 12 \\
\hline
\end{tabular}




\begin{tabular}{|c|c|c|c|c|}
\hline \multirow[t]{2}{*}{ Green Globes } & \multirow[t]{2}{*}{ Maximum Points } & \multicolumn{3}{|c|}{ Dimension of Sustainability } \\
\hline & & Social & Economic & Environment \\
\hline Building Opaque Envelope & 31 & & & 31 \\
\hline Lighting & 36 & 36 & & \\
\hline HVAC Systems and Controls & 59 & & & 59 \\
\hline Other HVAC Systems and Controls & 32 & & & 32 \\
\hline $\begin{array}{l}\text { Other Energy Efficient Equipment and } \\
\text { Measures }\end{array}$ & 11 & & * & \\
\hline Renewable Energy & 50 & & & \\
\hline Energy Efficient Transportation & 24 & 12 & & 12 \\
\hline Water & 110 & & & \\
\hline Water Consumption & 42 & & & 42 \\
\hline Cooling Towers & 9 & & & 9 \\
\hline Boilers and Water Heaters & 4 & & & 4 \\
\hline Water Intensive Applications & 18 & & & 18 \\
\hline Water Treatment & 3 & & & 3 \\
\hline Alternate Sources of Water & 5 & & & 5 \\
\hline Metering & 11 & & * & 11 \\
\hline Irrigation & 18 & & & 18 \\
\hline Materials and Resources & 125 & & & \\
\hline $\begin{array}{l}\text { Building Assembly (core and shell } \\
\text { including envelope) }\end{array}$ & 33 & & & 33 \\
\hline $\begin{array}{l}\text { Interior Fit-outs (Including Finishes and } \\
\text { Furnishings) }\end{array}$ & 16 & & & 16 \\
\hline Re-use of Existing Structures & 26 & & $*$ & 26 \\
\hline Waste & 9 & & & 9 \\
\hline Building Service Life Plan & 7 & & & 7 \\
\hline Resource Conservation & 6 & & & 6 \\
\hline Envelope-Roofing/Openings & 10 & & & 10 \\
\hline Envelope-Foundation, Waterproofing & 6 & & & 6 \\
\hline Envelope-Cladding & 5 & & & 5 \\
\hline Envelope-Barriers & 7 & & & 7 \\
\hline Emissions & 50 & & & \\
\hline Heating & 18 & & & 18 \\
\hline Cooling & 29 & & & 29 \\
\hline Janitorial Equipment & 3 & 3 & & \\
\hline Indoor Environment & 160 & & & \\
\hline Ventilation & 37 & 37 & & \\
\hline $\begin{array}{l}\text { Source Control and Measurement of } \\
\text { Indoor Pollutants }\end{array}$ & 46 & 46 & & \\
\hline Lighting Design and Systems & 30 & 30 & & \\
\hline Thermal Comfort & 18 & 18 & & \\
\hline Acoustic Comfort & 29 & 29 & & \\
\hline Total & & & & \\
\hline
\end{tabular}


Classification of different certification levels as per Green Globes rating for New Construction.

\begin{tabular}{ccc}
\hline Green Globes Percentage Score & Green Globes Rating & \begin{tabular}{c} 
Description \\
\hline $85-100 \%$
\end{tabular} \\
\hline $70-84 \%$ & 3 Globes & $\begin{array}{c}\text { Demonstrates national leadership and excellence } \\
\text { in the practice of energy, water, and } \\
\text { environmental efficiency to reduce environmental } \\
\text { impacts. }\end{array}$ \\
\hline $55-69 \%$ & 2 Globes & $\begin{array}{c}\text { Demonstrates leadership in applying best } \\
\text { practices regarding energy, water, and } \\
\text { environmental efficiency. }\end{array}$ \\
\hline $35-54 \%$ & 1 Globes & $\begin{array}{c}\text { Demonstrates excellent progress in the reduction } \\
\text { of environmental impacts and use of } \\
\text { environmental efficiency practices. }\end{array}$ \\
\hline $70-84 \%$ & 4 Globes & $\begin{array}{c}\text { Demonstrates a commitment to environmental } \\
\text { efficiency practices. }\end{array}$ \\
\hline & 3 Globes & $\begin{array}{c}\text { Demonstrates national leadership and excellence } \\
\text { in the practice of energy, water, and } \\
\text { environmental efficiency to reduce environmental } \\
\text { impacts. }\end{array}$ \\
\hline
\end{tabular}

GBI-Non-Residential Building Construction.

\begin{tabular}{|c|c|c|c|c|}
\hline \multirow{2}{*}{$\begin{array}{c}\text { GBI } \\
\text { ENERGY EFFICIENCY }\end{array}$} & \multirow{2}{*}{$\begin{array}{c}\text { Maximum Points } \\
38\end{array}$} & \multicolumn{3}{|c|}{ Dimension of Sustainability } \\
\hline & & Social & Economic & Environment \\
\hline \multicolumn{5}{|l|}{ Design \& Performance } \\
\hline Minimum EE Performance & 2 & & & 2 \\
\hline Lighting Zoning & 3 & & & 3 \\
\hline Electrical Sub-metering & 2 & & & 2 \\
\hline Renewable Energy & 5 & & & 5 \\
\hline Advanced or Improved EE Performance-BEI & 15 & & & 15 \\
\hline \multicolumn{5}{|l|}{ Commissioning } \\
\hline Enhanced or Re-commissioning & 4 & & & 4 \\
\hline On-going Post Occupancy Commissioning & 2 & 2 & & \\
\hline \multicolumn{5}{|l|}{ Monitoring, Improvement \& Maintenance } \\
\hline EE Monitoring \& Improvement & 2 & & & 2 \\
\hline Sustainable Maintenance & 3 & 2 & 1 & \\
\hline INDOOR ENVIRONMENTAL QUALITY & 21 & & & \\
\hline \multicolumn{5}{|l|}{ Air Quality } \\
\hline Minimum IAQ Performance & 1 & 1 & & \\
\hline Environmental Tobacco Smoke (ETS) Control & 1 & 1 & & \\
\hline Carbon Dioxide Monitoring and Control & 1 & 1 & & \\
\hline Indoor Air Pollutants & 2 & 2 & & \\
\hline Mould Prevention & 1 & 1 & & \\
\hline \multicolumn{5}{|l|}{ Thermal Comfort } \\
\hline Thermal Comfort: Controllability of Systems & 2 & 2 & & \\
\hline Air Change Effectiveness & 1 & 1 & & \\
\hline \multicolumn{5}{|l|}{ Lighting, Visual \& Acoustic Comfort } \\
\hline Daylighting & 2 & 2 & & \\
\hline Daylight Glare Control & 1 & 1 & & \\
\hline Electric Lighting Levels & 1 & & & 1 \\
\hline High-Frequency Ballasts & 1 & 1 & & \\
\hline External Views & 2 & 2 & & \\
\hline Internal Noise Levels & 1 & 1 & & \\
\hline \multicolumn{5}{|l|}{ Verification } \\
\hline IAQ Before/During Occupancy & 2 & 2 & & \\
\hline
\end{tabular}




\begin{tabular}{|c|c|c|c|c|}
\hline \multirow{2}{*}{$\begin{array}{c}\text { GBI } \\
\text { ENERGY EFFICIENCY }\end{array}$} & \multirow{2}{*}{$\begin{array}{c}\text { Maximum Points } \\
38\end{array}$} & \multicolumn{3}{|c|}{ Dimension of Sustainability } \\
\hline & & Social & Economic & Environment \\
\hline Occupancy Comfort Survey: Verification & 2 & 2 & & \\
\hline $\begin{array}{l}\text { SUSTAINABLE SITE PLANNING \& } \\
\text { MANAGEMENT }\end{array}$ & 10 & & & \\
\hline \multicolumn{5}{|l|}{ Facility Management } \\
\hline GBI Rated Design \& Construction & 1 & 1 & & \\
\hline Building Exterior Management & 1 & & & 1 \\
\hline $\begin{array}{l}\text { Integrated Pest Management, Erosion Control \& } \\
\text { Landscape Management }\end{array}$ & 1 & & & 1 \\
\hline \multicolumn{5}{|l|}{ Transportation } \\
\hline Green Vehicle Priority & 1 & & & 1 \\
\hline Parking Capacity & 1 & & & 1 \\
\hline \multicolumn{5}{|l|}{ Reduce Heat Island Effect } \\
\hline Greenery \& Roof & 4 & & & 4 \\
\hline Building User Manual & 1 & & & 1 \\
\hline MATERIALS \& RESOURCES & 9 & & & \\
\hline \multicolumn{5}{|l|}{ Reused \& Recycled Materials } \\
\hline Material Reuse and Selection & 1 & 1 & & \\
\hline Recycle Content Materials & 1 & & & 1 \\
\hline \multicolumn{5}{|l|}{ Sustainable Materials \& Resources and Policy } \\
\hline Sustainable Timber & 1 & 1 & & \\
\hline Sustainable Purchasing Policy & 1 & & 1 & \\
\hline \multicolumn{5}{|l|}{ Waste Management } \\
\hline Storage, Collection \& Disposal of recyclables & 3 & & & 3 \\
\hline \multicolumn{5}{|l|}{ Green Products } \\
\hline Refrigerants \& Clean Agents & 2 & & & 2 \\
\hline WATER EFFICIENCY & 12 & & & \\
\hline \multicolumn{5}{|l|}{ Water Harvesting \& Recycling } \\
\hline Rainwater Harvesting & 3 & & & 3 \\
\hline Water Recycling & 2 & & & 2 \\
\hline \multicolumn{5}{|l|}{ Increased Efficiency } \\
\hline Water Efficient—Irrigation/Landscaping & 2 & & & 2 \\
\hline Water Efficient Fittings & 3 & & & 3 \\
\hline Metering \& Leak Detection System & 2 & & & 2 \\
\hline INNOVATION & 10 & & & \\
\hline Innovation \& Environmental Initiatives & 9 & & & 9 \\
\hline Green Building Index Facilitator & 1 & 1 & & \\
\hline
\end{tabular}

Classification of different certification levels as per GBI-Non-Residential Building Construction.

\begin{tabular}{cc}
\hline Points & GBI Rating \\
\hline $86-100$ & Platinum \\
\hline $76-85$ & Gold \\
\hline $66-75$ & Silver \\
\hline $50-65$ & Certified \\
\hline
\end{tabular}

\section{GSAS Design \& Build Certification.}

\begin{tabular}{ccccc}
\hline GSAS & Maximum Points & & Dimension of Sustainability \\
\hline Urban Connectivity & 0.180 & Social & Economic & Environment \\
\hline Proximity to infrastructure & & & \\
\hline Proximity to amenities & & & \\
\hline Load on local traffic conditions & & \\
\hline
\end{tabular}




\begin{tabular}{|c|c|c|c|c|}
\hline \multirow{2}{*}{$\begin{array}{c}\text { GSAS } \\
\text { Urban Connectivity }\end{array}$} & \multirow{2}{*}{$\begin{array}{c}\text { Maximum Points } \\
0.180\end{array}$} & \multicolumn{3}{|c|}{ Dimension of Sustainability } \\
\hline & & Social & Economic & Environment \\
\hline \multicolumn{5}{|l|}{ Public transportation } \\
\hline \multicolumn{5}{|l|}{ Green transportation } \\
\hline \multicolumn{5}{|l|}{ Neighbourhood acoustics } \\
\hline Site & 0.510 & & & \\
\hline \multicolumn{5}{|l|}{ Land preservation } \\
\hline \multicolumn{5}{|l|}{ Waterbody preservation } \\
\hline \multicolumn{5}{|l|}{ Biodiversity preservation } \\
\hline \multicolumn{5}{|l|}{ Vegetation } \\
\hline \multicolumn{5}{|l|}{ Drain and stormwater contamination } \\
\hline \multicolumn{5}{|l|}{ Rainwater runoff } \\
\hline \multicolumn{5}{|l|}{ Heat island effect } \\
\hline \multicolumn{5}{|l|}{ Shading } \\
\hline \multicolumn{5}{|l|}{ Accessibility } \\
\hline \multicolumn{5}{|l|}{ External lighting } \\
\hline \multicolumn{5}{|l|}{ Light pollution } \\
\hline \multicolumn{5}{|l|}{ Noise pollution } \\
\hline \multicolumn{5}{|l|}{ Eco-Parking } \\
\hline \multicolumn{5}{|l|}{ Mixed use } \\
\hline \multicolumn{5}{|l|}{ Construction practices } \\
\hline Energy & 0.720 & & & \\
\hline \multicolumn{5}{|l|}{ Thermal energy demand performance } \\
\hline Energy use performance & & & & \\
\hline Primary energy performance & & & & \\
\hline $\mathrm{CO}_{2}$ emissions & & & & \\
\hline Energy sub-metering & & & $*$ & \\
\hline Water & 0.480 & & & \\
\hline Water demand performance & & & & \\
\hline Water reuse performance & & & & \\
\hline Water sub-metering & & & & \\
\hline Materials & 0.270 & & & \\
\hline Locally sourced material & & & $*$ & \\
\hline Material eco-labelling & & & $*$ & \\
\hline Recycled content of materials & & & * & \\
\hline Material reuse & & & $*$ & \\
\hline Existing structure reuse & & & * & \\
\hline Design for disassembly & & & * & \\
\hline Responsible sourcing of material & & & * & \\
\hline Indoor Environment & 0.570 & & & \\
\hline Thermal comfort & & & & \\
\hline Natural ventilation & & & & \\
\hline Mechanical ventilation & & & & \\
\hline Lighting & & & & \\
\hline Daylight & & & & \\
\hline Glare & & & & \\
\hline Views & & & & \\
\hline Acoustics & & & & \\
\hline Low VOC-materials & & & & \\
\hline Airborne contaminants & & & & \\
\hline
\end{tabular}




\begin{tabular}{|c|c|c|c|}
\hline \multirow{2}{*}{$\frac{\text { GSAS }}{\text { Urban Connectivity }}$} & \multirow{2}{*}{$\begin{array}{c}\text { Maximum Points } \\
0.180\end{array}$} & \multicolumn{2}{|c|}{ Dimension of Sustainability } \\
\hline & & Economic & Environment \\
\hline Cultural \& Economic Value & 0.120 & & \\
\hline \multicolumn{4}{|l|}{ Heritage and cultural identity } \\
\hline \multicolumn{4}{|l|}{ Support of national economy } \\
\hline Management and Operations & 0.150 & & \\
\hline \multicolumn{4}{|l|}{ Systems commissioning } \\
\hline \multicolumn{4}{|l|}{ Waste management } \\
\hline \multicolumn{4}{|l|}{ Facility management } \\
\hline \multicolumn{4}{|l|}{ Leak detection systems } \\
\hline \multicolumn{4}{|l|}{ Automated control systems } \\
\hline \multicolumn{4}{|l|}{ Transportation systems in building } \\
\hline Total & 3.0 & & \\
\hline \multicolumn{4}{|c|}{$\begin{array}{l}\text { * Category weight is divided equally among the category parameters. For example, the Site category points are } 0.510 \text { and } \\
\text { there are } 15 \text { category parameters hence score assumed for each parameter is } 0.510 / 15 \text { i.e., } 0.034 \text {. }\end{array}$} \\
\hline \multicolumn{4}{|c|}{ Classification of different certification levels as per GSAS Design \& Build. } \\
\hline $\begin{array}{l}\text { Score } \\
\end{array}$ & & Rating & \\
\hline $\mathrm{X}<0$ & & Certification denied & \\
\hline $0.00 \leq X \leq 0.50$ & & * & \\
\hline $0.50<\mathrm{X} \leq 1.00$ & & ** & \\
\hline $1.00<\mathrm{X} \leq 1.50$ & & $* * *$ & \\
\hline $1.50<\mathrm{X} \leq 2.00$ & & $* * * *$ & \\
\hline $2.00<X \leq 2.50$ & & $* * * * *$ & \\
\hline $2.50<X \leq 3.0$ & & $* * * * * *$ & \\
\hline
\end{tabular}

\section{Appendix B}

Table A1. Table of explanation refered from Table 2 in maintext.

Social Sustainability Parameters (Phase 1. Conceptual Planning and Feasibility Study)

Parameters

Stakeholders' consultation and engagement

\section{Further Explanation}

- Expectations of the owner, designer, and public early in the project i.e., community relationship and involvement

- Informing stakeholders about the project constraints like budget, schedule, location, size, design, and construction standards i.e., well-defined project scope and limitations

- $\quad$ Ensure participation of final users in design for understanding and anticipating their needs i.e., social apprehension of their needs-social design

- $\quad$ Establish partnering strategies for resolving interpersonal conflicts among project stakeholders

- The minimized project caused nuisances and disruptions like dust, noise, traffic, and others

- $\quad$ Provisions for public safety like barricading, signboards, and others

- Protecting local heritage (natural and cultural) from project's negative impact

- $\quad$ Empowering of young people, women, disadvantaged with better job opportunities, the creation of green jobs, and the conditions needed to create them i.e., sustainable employment

- Awareness training for social and environmental sustainability and education/training for skill development

- Concern for users' safety, health, productivity, privacy, and security

Accessibility of built facility through rail/road/public transit systems, universal accessibility through disabled-friendly features 
Table A1. Cont.

\begin{tabular}{|c|c|}
\hline \multicolumn{2}{|c|}{ Social Sustainability Parameters (Phase 1. Conceptual Planning and Feasibility Study) } \\
\hline Parameters & Further Explanation \\
\hline $\begin{array}{l}\text { Health and safety } \\
\text { considerations }\end{array}$ & $\begin{array}{l}\text { - Planning for worker's facilities such as drinking water, sewage, an } \\
\text { solid waste management, and others } \\
\text { - } \quad \text { Planning for female worker's specific health and safety facilities } \\
\text { - Conducting safety assessment/planning to identify any future } \\
\text { risk/safety issues to public and safety users }\end{array}$ \\
\hline $\begin{array}{c}\text { Ethical } \\
\text { considerations }\end{array}$ & $\begin{array}{l}\text { - } \quad \text { Corruption incidents' monitoring and prompt action against } \\
\text { - } \quad \text { Onethical conduct } \\
\text { - } \quad \text { Disclosure towards anti-corruption measures } \\
\text { - } \quad \text { Compliance with regulations to overcome ethical lapses } \\
\text { - Leadership appointments involving ethical considerations i.e., } \\
\text { avoiding any conflict of interest }\end{array}$ \\
\hline
\end{tabular}

\begin{tabular}{|c|c|}
\hline \multicolumn{2}{|c|}{ Social Sustainability Parameters (Phase 2. Design and Engineering) } \\
\hline Parameters & Further Explanation \\
\hline $\begin{array}{l}\text { Health, wellbeing, } \\
\text { and the environment }\end{array}$ & $\begin{array}{l}\text { - Design for better health and surrounding environment to promote } \\
\text { activity indoors and outdoors, and encourage physical health of } \\
\text { occupants } \\
\text { Design for better lifestyle practices, including nutrition, hydration, } \\
\text { and social connectivity for the occupants } \\
\text { - Design for reducing infectious disease transmission within } \\
\text { constructed facility environment }\end{array}$ \\
\hline
\end{tabular}

\begin{tabular}{|c|c|}
\hline \multicolumn{2}{|r|}{ Social Sustainability Parameters (Phase 3. Construction) } \\
\hline Parameters & Further Explanation \\
\hline $\begin{array}{l}\text { Socio-economic } \\
\text { strategies for } \\
\text { workers }\end{array}$ & $\begin{array}{l}\text { - Ensure health (both physical and mental) and safety of workers by } \\
\text { minimizing unsafe acts and unsafe conditions like exposure to } \\
\text { hazardous materials, chemicals, carcinogenic substances, and others } \\
\text { - } \quad \text { Empowerment of females and promote gender equality among } \\
\text { construction workforce } \\
\text { Protect labour rights, ensure the workforce is free from forced, } \\
\text { trafficked, and child labour } \\
\text { - Ensure safe, clean, and habitable living conditions for workers - } \\
\text { Ensure access to grievance redressal mechanism for workers } \\
\text { Education schemes for construction workers for improving literacy } \\
\text { and skills especially targeting workers in certain geographies who } \\
\text { are working since childhood } \\
\text { Educating workers for continuous awareness about carbon-neutral } \\
\text { technologies and sustainability practices }\end{array}$ \\
\hline
\end{tabular}

\section{Social Sustainability Parameters (Phase 4. Operation and Maintenance)}

\begin{tabular}{cl}
\hline Parameters & \multicolumn{1}{c}{ Further Explanation } \\
\hline - & $\begin{array}{l}\text { Ensuring thermal comfort during the operational phase } \\
\text { Ensuring natural and energy-efficient lighting solutions during the } \\
\text { operational phase }\end{array}$ \\
$\begin{array}{l}\text { Prioritizing } \\
\text { occupant's comfort }\end{array}$ & - $\quad \begin{array}{l}\text { Ensuring acoustic comfort during the operational phase } \\
\text { operational phase } \\
\text { Ensure universal access to different ability people during the } \\
\text { operational phase }\end{array}$
\end{tabular}


Table A1. Cont.

\begin{tabular}{|c|c|}
\hline \multicolumn{2}{|c|}{ Social Sustainability Parameters (Phase 5. End-of-life) } \\
\hline Parameters & Further Explanation \\
\hline $\begin{array}{l}\text { Effective project } \\
\text { communication }\end{array}$ & $\begin{array}{l}\text { Disclosure to the public about dismantling process and } \\
\text { digital dissemination about the same } \\
\text { Disseminating information of building materials and } \\
\text { components and communicating with planners, } \\
\text { construction workers, and other active professionals } \\
\text { Disseminating information on effects on local environment } \\
\text { and measures taken to mitigate the same } \\
\text { - Managing communication among the stakeholders }\end{array}$ \\
\hline Security & $\begin{array}{l}\text { Ensure work and safety plan for the contaminated and } \\
\text { non-contaminated area } \\
\text { - } \quad \text { Ensure implementation of construction site ordinance } \\
\text { Ensure accessibility of the site only to the authorized } \\
\text { persons via protective measures }\end{array}$ \\
\hline
\end{tabular}

Table A2. Table of explanation refered from Table 3 in maintext.

\begin{tabular}{|c|c|}
\hline \multicolumn{2}{|c|}{ Economic Sustainability Parameters (Phase 5. End-of-Life) } \\
\hline Parameters & Further Explanation \\
\hline Values of expandable resources & $\begin{array}{l}\text { Estimating potential expandable } \\
\text { components and products, fixtures, and } \\
\text { furniture } \\
\text { - Assessing the components and } \\
\text { construction products potentially } \\
\text { expandable } \\
\text { Proactive analysis of identified potential } \\
\text { expandable components and fixtures } \\
\text { - Market analysis of identified potential } \\
\text { expandable components and fixtures }\end{array}$ \\
\hline Separation, recycling, and disposal & $\begin{array}{l}\text { Ensure characterization of material and } \\
\text { designation of quality levels } \\
\text { Measures to minimize the accumulated } \\
\text { rubble/mixed construction waste whose } \\
\text { separation is technically and } \\
\text { economically not feasible } \\
\text { Optimization of disposal and recycling } \\
\text { - } \quad \text { Meutes } \\
\text { use, and storage in material banks }\end{array}$ \\
\hline
\end{tabular}

\section{Appendix C}

Illustrative example highlighting the advantage of the proposed PWBDI/PIDI approach

Consider two projects which are evaluated using the GRIHA system, which assigns maximum credits of 24, 5 and 71 to social, economic, and environmental assessment respectively. The scores achieved by the two projects under the different sustainability dimensions are as given in the following table. 


\begin{tabular}{cccc}
\hline Description & \multicolumn{3}{c}{ Sustainability Dimension } \\
\cline { 2 - 4 } & Social & Economic & Environment \\
\hline Maximum credits & 24 & 5 & 71 \\
\hline $\begin{array}{c}\text { Assumed performance } \\
\text { score-PROJECT 1 }\end{array}$ & 14 & 1 & 65 \\
\hline $\begin{array}{c}\text { Assumed performance } \\
\text { score-PROJECT 2 }\end{array}$ & 9 & 3 & 68 \\
\hline
\end{tabular}

GRIHA rating for both the projects would be "*****" based on aggregate score of 80 . Project 1 scored low on economic assessment (20\%) but still achieved "****" while Project 2 scored low on social assessment (37.5\%) and still achieved "*****". To judge whether both the Project 1 and Project 2 are equally sustainable or one is more/less compared to other is critical. Hence, taking a simple 'arithmetic sum' of three scores and having that sum clear a pre-determined benchmark leaves a possibility of extremely low scores in one (or even two) dimension(s) and still qualifying for a high rating. This inherent lacuna is addressed by defining and adopting the PWBDI and PIDI approach as illustrated in following tables.

GRIHA scores in pre-construction phase.

\begin{tabular}{cccc}
\hline Description & \multicolumn{3}{c}{ Sustainability Dimension } \\
\cline { 2 - 4 } & Social & Economic & Environment \\
\hline Max. Credits & 24 & 5 & 71 \\
\hline $\begin{array}{c}\text { Assumed performance } \\
\text { score-PROJECT 1 }\end{array}$ & 14 & 1 & 65 \\
\hline $\begin{array}{c}\text { Assumed performance } \\
\text { score-PROJECT 2 }\end{array}$ & 9 & 3 & 68 \\
\hline $\begin{array}{c}\text { Normalized performance } \\
\text { score-PROJECT 1 }\end{array}$ & 0.58 & 0.20 & $\begin{array}{c}0.91 \text {; environment } \\
\text { non-conformance }\end{array}$ \\
\hline $\begin{array}{c}\text { Normalized performance } \\
\text { score-PROJECT 1 }\end{array}$ & 0.37 & 0.6 & $\begin{array}{c}0.96 ; \text { environment } \\
\text { non-conformance } \\
=1-0.96=0.04\end{array}$ \\
\hline $\begin{array}{c}\text { Base phase chain } \\
\text { number-PROJECT 1 }\end{array}$ & 1 & 1 & 1 \\
\hline Base phase chain-PROJECT 1 & 1 & 1 & 1 \\
\hline
\end{tabular}


GRIHA scoring in construction phase.

\begin{tabular}{cccc}
\hline \multirow{2}{*}{ Description } & Social & Economic & Environment \\
\cline { 2 - 4 } & 24 & 5 & 71 \\
\hline Max. Credits & 17 & 2 & 61 \\
\hline $\begin{array}{c}\text { Assumed performance } \\
\text { score-PROJECT 1 }\end{array}$ & 11 & 2 & 67 \\
\hline $\begin{array}{c}\text { Assumed performance } \\
\text { score-PROJECT 2 }\end{array}$ & 0.71 & 0.4 & $\begin{array}{c}0.86 \text {; environment } \\
\text { non-conformance } \\
=1-0.86=0.14\end{array}$ \\
\hline $\begin{array}{c}\text { Normalized performance } \\
\text { score-PROJECT 1 }\end{array}$ & 0.46 & 0.4 & $\begin{array}{c}0.94 ; \text { environment } \\
\text { non-conformance } \\
=1-0.94=0.06\end{array}$ \\
\hline $\begin{array}{c}\text { Normalized performance } \\
\text { score-PROJECT 2 }\end{array}$ & 1.22 & 2 & 1.55 \\
\hline $\begin{array}{c}\text { Current phase chain } \\
\text { number -PROJECT 1 }\end{array}$ & 1.24 & 0.67 & 1.5 \\
\hline $\begin{array}{c}\text { Current phase chain } \\
\text { number -PROJECT 2 }\end{array}$ & & 0.79 & \\
\hline $\begin{array}{c}\text { PWBDI Scenario } \\
\text {-PROJECT 1 }\end{array}$ & SOPn & & \\
\hline
\end{tabular}

As SOPn $>1$, ENPn $>1$ and PWBDI $<1$; It indicates that as the

Remark -PROJECT $1 \quad$ project-1 moves from pre-construction to construction phase, increase in social well-being is coupled with increasing environmental pressure

\begin{tabular}{|c|c|c|}
\hline PIDI -PROJECT 1 & \multicolumn{2}{|l|}{1.29} \\
\hline Remark -PROJECT 1 & \multicolumn{2}{|c|}{$\begin{array}{l}\text { As ECPn }>1 \text {, ENPn }>1 \text { and PIDI }>1 \text {; It indicates that as the project- } 1 \\
\text { moves from pre-construction to construction phase, increase in } \\
\text { economic well-being exceeds the increase in environmental pressure }\end{array}$} \\
\hline PWBDI -PROJECT 2 & \multicolumn{2}{|l|}{0.83} \\
\hline Remark -PROJECT 2 & \multicolumn{2}{|c|}{$\begin{array}{c}\text { As SOPn }>1 \text {, ENPn }>1 \text { and PWBDI }<1 \text {; It indicates that as the } \\
\text { project- } 2 \text { moves from pre-construction to construction phase, } \\
\text { increase in social well-being is coupled with increasing } \\
\text { environmental pressure }\end{array}$} \\
\hline PIDI -PROJECT 2 & \multicolumn{2}{|l|}{0.44} \\
\hline Remark -PROJECT 2 & \multicolumn{2}{|c|}{$\begin{array}{c}\text { As ECPn }<1 \text {, ENPn }>1 \text { and PIDI }<1 \text {; It indicates that as the project- } 2 \\
\text { moves from pre-construction to construction phase, economic } \\
\text { well-being decreases with increase in environmental pressure }\end{array}$} \\
\hline Description & $\begin{array}{l}\text { GRIHA Rating Based on Aggregate } \\
\text { Score } \\
\text { (Pre-Construction } \rightarrow \text { Construction) }\end{array}$ & $\begin{array}{l}\text { Interpretation Based on } \\
\text { PWBDI/PIDI Approach } \\
\quad \text { (PWBDI, PIDI) }\end{array}$ \\
\hline Project-1 & $* * * * \rightarrow * * * *$ & $(0.79,1.29)$ \\
\hline Project-2 & ${ }^{* * * *} \rightarrow^{* * * *}$ & $(0.83,0.44)$ \\
\hline & $\begin{array}{l}\text { Non-desirable state, which could not } \\
\text { aggregate scoring as offered by the }\end{array}$ & $\begin{array}{l}\text { ve been detected by mere } \\
\text { rating tools/schemes }\end{array}$ \\
\hline
\end{tabular}

It may be noted that based on aggregate scores different scenarios are possible and moreover when these projects move from one phase to other phase, they can behave differently irrespective of their base phase performance as illustrated by PWBDI and PIDI for the above two projects. 


\section{References}

1. United Nations-The General Assembly. Transforming Our World: The 2030 Agenda for Sustainable Development. 2015. Available online: https:/ / www.un.org/ga/search/view_doc.asp?symbol=A/RES/70/1\&Lang=E (accessed on 10 October 2020).

2. Heravi, G.; Fathi, M.; Faeghi, S. Evaluation of sustainability indicators of industrial buildings focused on petrochemical projects. J. Clean. Prod. 2015, 109, 92-107. [CrossRef]

3. World Green Building Council. The Benefits of Green Buildings. 2017. Available online: https://www.worldgbc.org/benefitsgreen-buildings (accessed on 18 October 2020).

4. Goh, C.S.; Chong, H.Y.; Jack, L.; Faris, A.F.M. Revisiting triple bottom line within the context of sustainable construction: A systematic review. J. Clean. Prod. 2020, 252, 119884. [CrossRef]

5. World Economic Forum. Shaping the Future of Construction: A Breakthrough in Mindset and Technology. 2016. Available online: https: / / www.weforum.org/reports/shaping-the-future-of-construction-a-breakthrough-in-mindset-and-technology (accessed on 6 December 2020).

6. Alawneh, R.; Ghazali, F.E.M.; Ali, H.; Asif, M. Assessing the contribution of water and energy efficiency in green buildings to achieve United Nations Sustainable Development Goals in Jordan. Build. Environ. 2018, 146, 119-132. [CrossRef]

7. Papajohn, D.; Brinker, C.; Asmar, M.E. Uncovering key criteria to assess sustainability rating systems for the built environment. In Construction Research Congress 2016; 2016; Volume 2016, pp. 1303-1312. Available online: https://doi.org/10.1061/9780784479 827.131 (accessed on 2 November 2021).

8. Sala, S.; Ciuffo, B.; Nijkamp, P. A systemic framework for sustainability assessment. Ecol. Econ. 2015, 119, 314-325. [CrossRef]

9. Andrade, J.; Bragança, L. Sustainability assessment of dwellings-a comparison of methodologies. Civ. Eng. Environ. Syst. 2016, 33, 125-146. [CrossRef]

10. Doan, D.T.; Ghaffarianhoseini, A.; Naismith, N.; Zhang, T.; Ghaffarianhoseini, A.; Tookey, J. A critical comparison of green building rating systems. Build. Environ. 2017, 123, 243-260. [CrossRef]

11. Awadh, O. Sustainability and green building rating systems: LEED, BREEAM, GSAS and Estidama critical analysis. J. Build. Eng. 2017, 11, 25-29. [CrossRef]

12. Mattoni, B.; Guattari, C.; Evangelisti, L.; Bisegna, F.; Gori, P.; Asdrubali, F. Critical review and methodological approach to evaluate the differences among international green building rating tools. Renew. Sustain. Energy Rev. 2018, 82, 950-960. [CrossRef]

13. Yu, W.D.; Cheng, S.T.; Ho, W.C.; Chang, Y.H. Measuring the Sustainability of construction projects throughout their lifecycle: A Taiwan lesson. Sustainability 2018, 10, 1523. [CrossRef]

14. UNEP. Decoupling Natural Resource Use and Environmental Impacts from Economic Growth. 2011. Available online: https: // wedocs.unep.org/handle/20.500.11822/31439 (accessed on 10 January 2021).

15. Wu, Y.; Chau, K.W.; Lu, W.; Shen, L.; Shuai, C.; Chen, J. Decoupling relationship between economic output and carbon emission in the Chinese construction industry. Environ. Impact Assess. Rev. 2018, 71, 60-69. [CrossRef]

16. Du, Q.; Zhou, J.; Pan, T.; Sun, Q.; Wu, M. Relationship of carbon emissions and economic growth in China's construction industry. J. Clean. Prod. 2019, 220, 99-109. [CrossRef]

17. Liang, Y.; Cai, W.; Ma, M. Carbon dioxide intensity and income level in the Chinese megacities' residential building sector: Decomposition and decoupling analyses. Sci. Total Environ. 2019, 677, 315-327. [CrossRef] [PubMed]

18. Sev, A. How can the construction industry contribute to sustainable development? A conceptual framework. Sustain. Dev. 2009, 17, 161-173. [CrossRef]

19. Said, H.; Berger, L. Future trends of sustainability design and analysis in construction industry and academia. Pract. Period. Struct. Des. Constr. 2014, 19,77-88. [CrossRef]

20. Svensson, G.; Wagner, B. Implementing and managing economic, social and environmental efforts of business sustainability. Manag. Environ. Qual. Int. J. 2015, 26, 195-213. [CrossRef]

21. Ellen Macarthur Foundation. Circularity in the Built Environment: Case Studies a Compilation of Case Studies from the ce100. 2016. Available online: https://www.ellenmacarthurfoundation.org/assets/downloads/Built-Env-Co.Project.pdf (accessed on 8 September 2020).

22. Iyer-Raniga, U.; Huovila, P.; Erasmus, P. Sustainable Buildings and Construction: Responding to the SDGs. Sustain. Cities Communities 2021. [CrossRef]

23. Nasir, M.H.A.; Genovese, A.; Acquaye, A.A.; Koh, S.C.L.; Yamoah, F. Comparing linear and circular supply chains: A case study from the construction industry. Int. J. Prod. Econ. 2017, 183, 443-457. [CrossRef]

24. Scheel, C.; Aguiñaga, E.; Bello, B. Decoupling Economic Development from the Consumption of Finite Resources Using Circular Economy. A Model for Developing Countries. Sustainability 2020, 12, 1291. [CrossRef]

25. Ellen Macarthur Foundation. The Built Environment Two Circular Investment Opportunities for a Low-Carbon and Prosperous Recovery. 2020. Available online: https:/ / www.ellenmacarthurfoundation.org/assets/downloads/The-Built-Environment.pdf (accessed on 2 February 2021).

26. Wallbaum, H.; Ostermeyer, Y.; Salzer, C.; Escamilla, E.Z. Indicator based sustainability assessment tool for affordable housing construction technologies. Ecol. Indic. 2012, 18, 353-364. [CrossRef]

27. Agol, D.; Latawiec, A.E.; Strassburg, B.B. Evaluating impacts of development and conservation projects using sustainability indicators: Opportunities and challenges. Environ. Impact Assess. Rev. 2014, 48, 1-9. [CrossRef] 
28. Illankoon, I.C.S.; Tam, V.W.; Le, K.N.; Shen, L. Key credit criteria among international green building rating tools. J. Clean. Prod. 2017, 164, 209-220. [CrossRef]

29. Parkin, S. Sustainable development: The concept and the practical challenge. In Proceedings of the Institution of Civil Engineers-Civil Engineering; Thomas Telford Ltd.: London, UK, 2000; Volume 138, No. 6; pp. 3-8.

30. Karji, A.; Woldesenbet, A.; Khanzadi, M. Social sustainability indicators in mass housing construction. In Proceedings of the 53rd ASC Annual International Conference Proceedings, Motif Hotel, Seattle, 5-8 April 2017; pp. 762-769. Available online: https:/ / digitalcommons.unl.edu/archengfacpub/127 (accessed on 2 November 2021).

31. Balkema, A.J.; Preisig, H.A.; Otterpohl, R.; Lambert, F.J. Indicators for the sustainability assessment of wastewater treatment systems. Urban Water 2002, 4, 153-161. [CrossRef]

32. Zhao, Z.Y.; Zhao, X.J.; Davidson, K.; Zuo, J. A corporate social responsibility indicator system for construction enterprises. J. Clean. Prod. 2012, 29, 277-289. [CrossRef]

33. Abidin, N.Z. Investigating the awareness and application of sustainable construction concept by Malaysian developers. Habitat Int. 2010, 34, 421-426. [CrossRef]

34. Munasinghe, M. Sustainomics: A Trans-disciplinary framework for making development more sustainable. Int. Soc. Ecol. Econ. 2004. [CrossRef]

35. Baloi, D.; Price, A.D. Modelling global risk factors affecting construction cost performance. Int. J. Proj. Manag. 2003, 21, 261-269. [CrossRef]

36. Goodland, R. The concept of environmental sustainability. Annu. Rev. Ecol. Syst. 1995, 26, 1-24. [CrossRef]

37. Yates, J.K.; Castro-Lacouture, D. Sustainability in Engineering Design and Construction; CRC Press: Boca Raton, FL, USA, 2018.

38. UNEP. Global Guidance Principles for Life Cycle Assessment Databases a Basis for Greener Processes and Products. Imprimerie Escourbiac. 2011. Available online: https://www.lifecycleinitiative.org/wp-content/uploads/2012/12/2011\%20-\%20Global\% 20Guidance\%20Principles.pdf (accessed on 7 March 2021).

39. Wulf, C.; Werker, J.; Ball, C.; Zapp, P.; Kuckshinrichs, W. Review of sustainability assessment approaches based on life cycles. Sustainability 2019, 11, 5717. [CrossRef]

40. Sala, S.; Farioli, F.; Zamagni, A. Life cycle sustainability assessment in the context of sustainability science progress (part 2). Int. J. Life Cycle Assess. 2013, 18, 1686-1697. [CrossRef]

41. Guinée, J. Life cycle sustainability assessment: What is it and what are its challenges. In Taking Stock of Industrial Ecology; Springer: Cham, Switzerland, 2016; pp. 45-68.

42. Hannouf, M.; Assefa, G. A life cycle sustainability assessment-based decision-analysis framework. Sustainability 2018, 10, 3863. [CrossRef]

43. Ji, Y.; Plainiotis, S. Design for Sustainability; China Architecture \& Building Press: Beijing, China, 2006.

44. Bal, M.; Bryde, D.; Fearon, D.; Ochieng, E. Stakeholder engagement: Achieving sustainability in the construction sector. Sustainability 2013, 5, 695-710. [CrossRef]

45. Herazo, B.; Lizarralde, G. Understanding stakeholders' approaches to sustainability in building projects. Sustain. Cities Soc. 2016, 26, 240-254. [CrossRef]

46. Fletcher, R.; Rammelt, C. Decoupling: A key fantasy of the post-2015 sustainable development agenda. Globalizations 2017, 14, 450-467. [CrossRef]

47. Stanitsas, M.; Kirytopoulos, K.; Leopoulos, V. Integrating sustainability indicators into project management: The case of construction industry. J. Clean. Prod. 2020, 279, 123774. [CrossRef]

48. Glass, J.; Simmonds, M. “Considerate construction": Case studies of current practice. Eng. Constr. Archit. Manag. 2007, 14, 131-149. [CrossRef]

49. Ugwu, O.O.; Haupt, T.C. Key performance indicators and assessment methods for infrastructure sustainability-A South African construction industry perspective. Build. Environ. 2007, 42, 665-680. [CrossRef]

50. Edum-Fotwe, F.T.; Price, A.D. A social ontology for appraising sustainability of construction projects and developments. Int. J. Proj. Manag. 2009, 27, 313-322. [CrossRef]

51. Mills, F.T.; Glass, J. The construction design manager's role in delivering sustainable buildings. Archit. Eng. Des. Manag. 2009, 5, 75-90. [CrossRef]

52. Valdes-Vasquez, R.; Klotz, L.E. Social sustainability considerations during planning and design: Framework of processes for construction projects. J. Constr. Eng. Manag. 2013, 139, 80-89. [CrossRef]

53. Cheng, E.W.; Kelly, S.; Ryan, N. Use of safety management practices for improving project performance. Int. J. Inj. Control Saf. Promot. 2015, 22, 33-39. [CrossRef]

54. Almahmoud, E.; Doloi, H.K. Assessment of social sustainability in construction projects using social network analysis. Facilities 2015, 33, 152-176. [CrossRef]

55. Abdel-Raheem, M.; Ramsbottom, C. Factors affecting social sustainability in highway projects in Missouri. Procedia Eng. 2016, 145, 548-555. [CrossRef]

56. Pocock, J.; Steckler, C.; Hanzalova, B. Improving socially sustainable design and construction in developing countries. Procedia Eng. 2016, 145, 288-295. [CrossRef]

57. O'Connor, J.T.; Torres, N.; Woo, J. Sustainability actions during the construction phase. J. Constr. Eng. Manag. 2016, $142,04016016$. [CrossRef] 
58. Sodangi, M. Overcoming the constraints to the adoption of sustainable civil engineering practices. Int. J. Constr. Manag. 2019, 21, 490-507. [CrossRef]

59. Farzanehrafat, M.; Akbarnezhad, A.; Ghoddousi, P. Analysis of different views towards social sustainability in construction. In ISARC. Proceedings of the International Symposium on Automation and Robotics in Construction; IAARC Publications, 2015; Volume 32, p. 1. Available online: https://www.iaarc.org/publications/2015_proceedings_of_the_32st_isarc_oulu_finland/analysis_of_ different_views_towards_social_sustainability_in_construction.html (accessed on 2 November 2021).

60. Sierra, L.A.; Yepes, V.; Pellicer, E. A review of multi-criteria assessment of the social sustainability of infrastructures. J. Clean. Prod. 2018, 187, 496-513. [CrossRef]

61. Lakhani, R. Occupational health of women construction workers in the unorganised sector. J. Health Manag. 2004, 6, 187-200. [CrossRef]

62. Vee, C.; Skitmore, C. Professional ethics in the construction industry. Eng. Constr. Archit. Manag. 2003, 10, 117-127. [CrossRef]

63. Moodley, K.; Smith, N.; Preece, C.N. Stakeholder matrix for ethical relationships in the construction industry. Constr. Manag. Econ. 2008, 26, 625-632. [CrossRef]

64. Hartley, R. Fighting corruption in the Australian construction industry: The national code of practice. Leadersh. Manag. Eng. 2009, 9, 131-135. [CrossRef]

65. Oladinrin, O.T.; Ho, C.M. Critical enablers for codes of ethics implementation in construction organizations. J. Manag. Eng. 2016, 32, 04015023. [CrossRef]

66. Saenz, C.; Brown, H. The disclosure of anticorruption aspects in companies of the construction sector: Main companies worldwide and in Latin America. J. Clean. Prod. 2018, 196, 259-272. [CrossRef]

67. Alkhatib, O.J.; Abdou, A. An ethical (descriptive) framework for judgment of actions and decisions in the construction industry and engineering-Part I. Sci. Eng. Ethics 2018, 24, 585-606. [CrossRef] [PubMed]

68. World Green Building Council. The World GBC's Health \& Wellbeing Framework Six Principles for a Healthy, Sustainable Built Environment. 2020. Available online: https://worldgbc.org/health-framework (accessed on 5 March 2021).

69. UKGBC. Social Value in New Development: An Introductory Guide for Local Authorities and Development Teams S. 2018. Available online: https://www.ukgbc.org/wp-content/uploads/2018/03/Social-Value.pdf (accessed on 8 February 2021).

70. Griha Council. Griha v.2019 Abridged Manual; The Energy and Resources Institute (TERI): New Delhi, India, 2019; Available online: https:/ /www.grihaindia.org/sites/default/files/pdf/Manuals/griha-v2019-abridged-manual.pdf (accessed on 23 October 2020).

71. Building Responsibly. Building Responsibly Collaborating to Promote the Welfare of Workers in the Engineering and Construction Industry, 2017. Available online: https:/ / static1.squarespace.com/static/5aa2d2d82971141ff9a61ea5/t/5eb2925fa9dc2768b0a7 d51b/1588761202701/Building+Responsibly_Worker+Welfare+Principles.pdf (accessed on 19 October 2020).

72. ASHRAE Standards \& Guidelines. Standard for the Design of High-Performance Green Buildings. 2018. Available online: https:/ / www.ashrae.org/technical-resources/bookstore/standard-189-1 (accessed on 18 October 2020).

73. Du Plessis, C. Agenda 21 for sustainable construction in developing countries. CSIR Rep. BOU E 2002, $204,2-5$.

74. Loosemore, M.; Chau, D.W. Racial discrimination towards Asian operatives in the Australian construction industry. Constr. Manag. Econ. 2002, 20, 91-102. [CrossRef]

75. Mitullah, W. Informal Labour in The Construction Industry in Kenya; University of Nairobi: Nairobi, Kenya, 2003.

76. Shen, L.Y.; Li Hao, J.; Tam, V.W.Y.; Yao, H. A checklist for assessing sustainability performance of construction projects. J. Civ. Eng. Manag. 2007, 13, 273-281. [CrossRef]

77. Baruah, B. Gender and globalization: Opportunities and constraints faced by women in the construction industry in India. Labor Stud. J. 2010, 35, 198-221. [CrossRef]

78. Tjoe Nij, E.; Hilhorst, S.; Spee, T.; Spierings, J.; Steffens, F.; Lumens, M.; Heederik, D. Dust control measures in the construction industry. Ann. Occup. Hyg. 2003, 47, 211-218. [PubMed]

79. Thomas, N.I.R.; Costa, D.B. Adoption of environmental practices on construction sites. Ambiente Construído 2017, 17, 9-24. [CrossRef]

80. Paul, W.L.; Taylor, P.A. A comparison of occupant comfort and satisfaction between a green building and a conventional building. Build. Environ. 2008, 43, 1858-1870. [CrossRef]

81. Ioan, S.; Călin, S. Olfactory comfort assurance in buildings. Chem. Emiss. Control Radioact. Pollut. Indoor Air Qual. $2011,407$. [CrossRef]

82. Bernardini, E.; Spence, S.M.; Kwon, D.K.; Kareem, A. Performance-based design of high-rise buildings for occupant comfort. J. Struct. Eng. 2015, 141, 04014244. [CrossRef]

83. Andargie, M.S.; Touchie, M.; O’Brien, W. A review of factors affecting occupant comfort in multi-unit residential buildings. Build. Environ. 2019, 160, 106182. [CrossRef]

84. Evans, G.W. The built environment and mental health. J. Urban Health 2003, 80, 536-555. [CrossRef] [PubMed]

85. Hoisington, A.J.; Stearns-Yoder, K.A.; Schuldt, S.J.; Beemer, C.J.; Maestre, J.P.; Kinney, K.A.; Postolache, T.T.; Lowry, C.A.; Brenner, L.A. Ten questions concerning the built environment and mental health. Build. Environ. 2019, 155, 58-69. [CrossRef]

86. Campbell, M.A.; Gunning, J.G. Strategies to improve mental health and well-being within the UK construction industry. Proc. Inst. Civ. Eng. Manag. Procure. Law 2020, 173, 64-74. [CrossRef] 
87. Lingard, H.; Lin, J. Career, family and work environment determinants of organizational commitment among women in the Australian construction industry. Constr. Manag. Econ. 2004, 22, 409-420. [CrossRef]

88. Karakhan, A.A.; Gambatese, J.A.; Simmons, D.R.; Al-Bayati, A.J. Identifying Pertinent Indicators for Assessing and Fostering Diversity, Equity, and Inclusion of the Construction Workforce. J. Manag. Eng. 2021, 37, 04020114. [CrossRef]

89. Hübner, F.; Volk, R.; Kühlen, A.; Schultmann, F. Review of project planning methods for deconstruction projects of buildings. Built Environ. Proj. Asset Manag. 2017, 7, 212-226. [CrossRef]

90. German Sustainable Building Council. DGNB Criteria Set-Deconstruction of Buildings. 2020. Available online: https://www. dgnb-system.de/de/gebaeude/rueckbau/kriterien/ (accessed on 30 November 2020).

91. Yeheyis, M.; Hewage, K.; Alam, M.S.; Eskicioglu, C.; Sadiq, R. An overview of construction and demolition waste management in Canada: A lifecycle analysis approach to sustainability. Clean Technol. Environ. Policy 2013, 15, 81-91. [CrossRef]

92. Enshassi, A.; Kochendoerfer, B.; Al Ghoul, H. Factors affecting sustainable performance of construction projects during project life cycle phases. Int. J. Sustain. Constr. Eng. Technol. 2016, 7. Available online: http://hdl.handle.net/20.500.12358/26557 (accessed on 2 November 2021).

93. Vardon, M.; Castaneda, J.P.; Nagy, M.; Schenau, S. How the System of Environmental-Economic Accounting can improve environmental information systems and data quality for decision making. Environ. Sci. Policy 2018, 89, 83-92. [CrossRef]

94. UNEP. System of Environmental-Economic Accounting-Ecosystem Accounting. 2021. Available online: https://unstats.un.org/ unsd/statcom/52nd-session/documents/BG-3f-SEEA-EA_Final_draft-E.pdf (accessed on 4 February 2021).

95. Perry, J.G.; Hayes, R.W. Risk and its management in construction projects. Proc. Inst. Civ. Eng. 1985, 78, 499-521. [CrossRef]

96. Martens, M.L.; Carvalho, M.M. Key factors of sustainability in project management context: A survey exploring the project managers' perspective. Int. J. Proj. Manag. 2017, 35, 1084-1102. [CrossRef]

97. Chan, A.P.; Scott, D.; Lam, E.W. Framework of success criteria for design/build projects. J. Manag. Eng. 2002, 18, 120-128. [CrossRef]

98. Pulaski, M.H.; Horman, M.J. Organizing constructability knowledge for design. J. Constr. Eng. Manag. 2005, 131, 911-919. [CrossRef]

99. Lind, H.; Brunes, F. Explaining cost overruns in infrastructure projects: A new framework with applications to Sweden. Constr. Manag. Econ. 2015, 33, 554-568. [CrossRef]

100. Dahl, P.; Horman, M.; Pohlman, T.; Pulaski, M. Evaluating design-build-operate-maintain delivery as a tool for sustainability. In Construction Research Congress 2005: Broadening Perspectives; 2005; pp. 1-10. Available online: https://doi.org/10.1061/40754(183) 27 (accessed on 2 November 2021). [CrossRef]

101. Spooner, K.; Kaine, S. Defining sustainability and human resource management. Int. Employ. Relat. Rev. 2010, $16,70-81$.

102. Othman, I.; Idrus, A.; Napiah, M. Human resource management in the construction of a sustainable development project: Towards successful completion. WIT Trans. Ecol. Environ. 2012, 162, 169-180.

103. Siew, R.Y.J. Human resource management in the construction industry-Sustainability competencies. Constr. Econ. Build. 2014, 14, 87-103. [CrossRef]

104. Siew, R.Y.J. Integrating sustainability into construction project portfolio management. KSCE J. Civ. Eng. 2016, 20, 101-108. [CrossRef]

105. Simatupang, T.M.; Sridharan, R. The collaboration index: A measure for supply chain collaboration. Int. J. Phys. Distrib. Logist. Manag. 2005, 35, 44-62. [CrossRef]

106. Adetunji, I.; Price, A.D.F.; Fleming, P. Achieving sustainability in the construction supply chain. In Proceedings of the Institution of Civil Engineers-Engineering Sustainability; Thomas Telford Ltd.: London, UK, 2008; Volume 161, No. 3; pp. 161-172.

107. Pero, M.; Moretto, A.; Bottani, E.; Bigliardi, B. Environmental collaboration for sustainability in the construction industry: An exploratory study in Italy. Sustainability 2017, 9, 125. [CrossRef]

108. Dadhich, P.; Genovese, A.; Kumar, N.; Acquaye, A. Developing sustainable supply chains in the UK construction industry: A case study. Int. J. Prod. Econ. 2015, 164, 271-284. [CrossRef]

109. Meng, X. Change in UK construction: Moving toward supply chain collaboration. J. Civ. Eng. Manag. 2013, 19, 422-432. [CrossRef]

110. Banchuen, P.; Sadler, I.; Shee, H. Supply chain collaboration aligns order-winning strategy with business outcomes. IIMB Manag. Rev. 2017, 29, 109-121. [CrossRef]

111. Spence, R.; Mulligan, H. Sustainable development and the construction industry. Habitat Int. 1995, 19, 279-292. [CrossRef]

112. Abdulsalam, D.; Faki, A.I.; Dardau, A.A. Impact assessment of incentive schemes for the sustainable development of Nigerian construction industry. J. Civ. Eng. Archit. 2012, 6, 1194. [CrossRef]

113. Avilova, I.; Krutilova, M.; Peresypkina, E. Economic incentives of green standards in civil and municipal engineering. Int. Multidiscip. Sci. GeoConf. SGEM 2017, 17, 255-261.

114. Gan, X.; Zuo, J.; Wu, P.; Wang, J.; Chang, R.; Wen, T. How affordable housing becomes more sustainable? A stakeholder study. J. Clean. Prod. 2017, 162, 427-437. [CrossRef]

115. Adams, K.T.; Osmani, M.; Thorpe, T.; Thornback, J. Circular economy in construction: Current awareness, challenges, and enablers. In Proceedings of the Institution of Civil Engineers-Waste and Resource Management; Thomas Telford Ltd.: London, UK, 2017; Volume 170, No. 1; pp. 15-24.

116. Schneiderova-Heralova, R. Importance of life cycle costing for construction projects. Eng. Rural Dev. 2018, 17, $1223-1227$. 
117. Manege, S.L.; Kennedy, C.J. Investigating whole life costing awareness in Tanzania building construction industry. Int. J. Constr. Manag. 2020, 1-8. [CrossRef]

118. Kagioglou, M.; Cooper, R.; Aouad, G. Performance management in construction: A conceptual framework. Constr. Manag. Econ. 2001, 19, 85-95. [CrossRef]

119. Larsen, J.K.; Shen, G.Q.; Lindhard, S.M.; Brunoe, T.D. Factors affecting schedule delay, cost overrun, and quality level in public construction projects. J. Manag. Eng. 2016, 32, 04015032. [CrossRef]

120. Li, X.; Xu, J.; Zhang, Q. Research on construction schedule management based on BIM technology. Procedia Eng. 2017, 174, 657-667. [CrossRef]

121. Rumane, A.R. Quality Management in Construction Projects; CRC Press: Boca Raton, FL, USA, 2017.

122. Levy, S.M. Project Management in Construction; McGraw-Hill Education: New York, NY, USA, 2018.

123. Dubois, A.; Gadde, L.E. The construction industry as a loosely coupled system: Implications for productivity and innovation. Constr. Manag. Econ. 2002, 20, 621-631. [CrossRef]

124. Dulaimi, M.F.; Ling, F.Y.Y.; Ofori, G.; Silva, N.D. Enhancing integration and innovation in construction. Build. Res. Inf. 2002, 30, 237-247. [CrossRef]

125. Park, H.S. Conceptual framework of construction productivity estimation. KSCE J. Civ. Eng. 2006, 10, 311-317. [CrossRef]

126. Ries, R.; Bilec, M.M.; Gokhan, N.M.; Needy, K.L. The economic benefits of green buildings: A comprehensive case study. Eng. Econ. 2006, 51, 259-295. [CrossRef]

127. Dobiáš, J.; Macek, D. Leadership in Energy and Environmental Design (LEED) and its impact on building operational expenditures. Procedia Eng. 2014, 85, 132-139. [CrossRef]

128. German Sustainable Building Council. DGNB System-Buildings in Use Criteria Set VERSION 2020. Deutsche Gesellschaft für Nachhaltiges Bauen. 2020. Available online: https:/ / static.dgnb.de/fileadmin/dgnb-system/downloads/criteria/DGNBCriteria-Set-Buildings-In-Use-Version-2020.pdf (accessed on 24 November 2020).

129. Finch, E.; Jones, K.; Sharp, M. A new performance-based process model for built asset maintenance. Facilities 2007, $25,525-535$.

130. Wibowo, M.A.; Handayani, N.U.; Mustikasari, A. Factors for implementing green supply chain management in the construction industry. J. Ind. Eng. Manag. 2018, 11, 651-679. [CrossRef]

131. Villena, V.H. The missing link? The strategic role of procurement in building sustainable supply networks. Prod. Oper. Manag. 2019, 28, 1149-1172. [CrossRef]

132. Dantata, N.; Touran, A.; Wang, J. An analysis of cost and duration for deconstruction and demolition of residential buildings in Massachusetts. Resour. Conserv. Recycl. 2005, 44, 1-15. [CrossRef]

133. Akbarnezhad, A.; Ong, K.C.G.; Chandra, L.R. Economic and environmental assessment of deconstruction strategies using building information modeling. Autom. Constr. 2014, 37, 131-144. [CrossRef]

134. Duran, X.; Lenihan, H.; O'Regan, B. A model for assessing the economic viability of construction and demolition waste recyclingThe case of Ireland. Resour. Conserv. Recycl. 2006, 46, 302-320. [CrossRef]

135. Zheng, L.; Wu, H.; Zhang, H.; Duan, H.; Wang, J.; Jiang, W.; Dong, B.; Liu, G.; Zuo, J.; Song, Q. Characterizing the generation and flows of construction and demolition waste in China. Constr. Build. Mater. 2017, 136, 405-413. [CrossRef]

136. Sanchez, B.; Rausch, C.; Haas, C. Deconstruction programming for adaptive reuse of buildings. Autom. Constr. $2019,107,102921$. [CrossRef]

137. Rašković, M.; Ragossnig, A.M.; Kondracki, K.; Ragossnig-Angst, M. Clean construction and demolition waste material cycles through optimised pre-demolition waste audit documentation: A review on building material assessment tools. Waste Manag. Res. 2020, 38, 923-941. [CrossRef]

138. Kibert, C.J.; Chini, A.R. August. Overview of Deconstruction in Selected Countries; CIB Publication: Ottawa, ON, Canada, 2000; Volume 252.

139. Tam, C.M.; Tam, V.W.; Tsui, W.S. Green construction assessment for environmental management in the construction industry of Hong Kong. Int. J. Proj. Manag. 2004, 22, 563-571. [CrossRef]

140. Ding, G.K. Sustainable construction-The role of environmental assessment tools. J. Environ. Manag. 2008, 86, 451-464. [CrossRef] [PubMed]

141. Li, X.; Zhu, Y.; Zhang, Z. An LCA-based environmental impact assessment model for construction processes. Build. Environ. 2010, 45, 766-775. [CrossRef]

142. Letmathe, P.; Doost, R.K. Environmental cost accounting and auditing. Manag. Audit. J. 2000, 15, 424-431. [CrossRef]

143. Ding, G.K. Life cycle assessment (LCA) of sustainable building materials: An overview. Eco-Effic. Constr. Build. Mater. 2014, 38-62. [CrossRef]

144. Bredenoord, J. Sustainable building materials for low-cost housing and the challenges facing their technological developments: Examples and lessons regarding bamboo, earth-block technologies, building blocks of recycled materials, and improved concrete panels. J. Archit. Eng. Technol. 2017, 6,1-11. [CrossRef]

145. Estokova, A.; Samesova, D. Sustainable Building Materials and Life Cycle Assessment. Sustainability 2021, 13, 2012. [CrossRef]

146. Kellert, S.R. Dimensions, elements, and attributes of biophilic design. In Biophilic Design: The Theory, Science and Practice of Bringing Buildings to Life; Wiley: Hoboken, NJ, USA, 2008; pp. 3-19.

147. Kellert, S.R. Nature by Design: The Practice of Biophilic Design; Yale University Press: New Haven, CT, USA, 2018. 
148. Kellert, S.R.; Heerwagen, J.; Mador, M. Biophilic Design: The Theory, Science and Practice of Bringing Buildings to Life; John Wiley \& Sons: Hoboken, NJ, USA, 2011.

149. DeZuane, J. Handbook of Drinking Water Quality; John Wiley \& Sons: Hoboken, NJ, USA, 1997.

150. WHO. Air Quality Air Quality Guidelines Global Update 2005 Guidelines Global Update 2005 A. WHO Regional Office for Europe. 2005. Available online: https://www.euro.who.int/_data/assets/pdf_file/0005/78638/E90038.pdf (accessed on 14 November 2020).

151. WHO. Guidelines for Drinking-Water Quality; WHO Press: Geneva, Switzerland, 2008; Available online: https: / / www.euro.who. int/_data/assets/pdf_file/0005/78638/E90038.pdf (accessed on 10 November 2020).

152. Yang, C.T.; Liao, C.J.; Liu, J.C.; Den, W.; Chou, Y.C.; Tsai, J.J. Construction and application of an intelligent air quality monitoring system for healthcare environment. J. Med. Syst. 2014, 38, 1-10. [CrossRef] [PubMed]

153. Hossaini, N.; Hewage, K.; Sadiq, R. Spatial life cycle sustainability assessment: A conceptual framework for net-zero buildings. Clean Technol. Environ. Policy 2015, 17, 2243-2253. [CrossRef]

154. Karlsson, I.; Rootzén, J.; Johnsson, F. Reaching net-zero carbon emissions in construction supply chains-Analysis of a Swedish road construction project. Renew. Sustain. Energy Rev. 2020, 120, 109651. [CrossRef]

155. Son, H.; Kim, C.; Chong, W.K.; Chou, J.S. Implementing sustainable development in the construction industry: Constructors' perspectives in the US and Korea. Sustain. Dev. 2011, 19, 337-347. [CrossRef]

156. Kucukvar, M.; Tatari, O. Towards a triple bottom-line sustainability assessment of the US construction industry. Int. J. Life Cycle Assess. 2013, 18, 958-972. [CrossRef]

157. Waidyasekara, K.G.A.S.; De Silva, L.; Rameezdeen, R. Water use efficiency and conservation during construction: Drivers, barriers and practices. Built Environ. Proj. Asset Manag. 2016, 6, 553-566. [CrossRef]

158. Furlong, C.; Jegatheesan, J.; Currell, M.; Iyer-Raniga, U.; Khan, T.; Ball, A.S. Is the global public willing to drink recycled water? A review for researchers and practitioners. Util. Policy 2019, 56, 53-61. [CrossRef]

159. Wu, Z.; Wu, Z.; Li, H.; Zhang, X.; Jiang, M. Developing a strategic framework for adopting water-saving measures in construction projects. Environ. Geochem. Health 2020, 42, 955-968. [CrossRef]

160. Spiegel, R.; Meadows, D. Green Building Materials: A Guide to Product Selection and Specification; John Wiley \& Sons: Hoboken, NJ, USA, 2010.

161. Llatas, C. A model for quantifying construction waste in projects according to the European waste list. Waste Manag. 2011, 31, 1261-1276. [CrossRef] [PubMed]

162. Kim, J.T.; Yu, C.W. Hazardous materials in buildings. Indoor Built Environ. 2014, 23, 44-61. [CrossRef]

163. Velenturf, A.P.; Archer, S.A.; Gomes, H.I.; Christgen, B.; Lag-Brotons, A.J.; Purnell, P. Circular economy and the matter of integrated resources. Sci. Total Environ. 2019, 689, 963-969. [CrossRef] [PubMed]

164. Schneider, P.; Schwerdt, S.; Schulz, K.; Fiebig, S.; Mirschel, D. Feasibility of substitute building materials for circular use in urban green infrastructure: Dresden Nexus Conference 2020-Session 4-Circular Economy for Building with Secondary Construction Materials to Minimise Resource use and Land use. Civ. Eng. Des. 2020, 2, 159-168. [CrossRef]

165. Council, U.G.B. US Green Building Council; US Green Building Council: Washington, DC, USA, 1998.

166. Guo, Y.; Baetz, B.W. Sizing of rainwater storage units for green building applications. J. Hydrol. Eng. 2007, 12, 197-205. [CrossRef]

167. Ching, F.D.; Shapiro, I.M. Green Building Illustrated; John Wiley \& Sons: Hoboken, NJ, USA, 2020.

168. Kijak, R.; Moy, D. A decision support framework for sustainable waste management. J. Ind. Ecol. 2004, 8, 33-50. [CrossRef]

169. Wu, Z.; Shen, L.; Ann, T.W.; Zhang, X. A comparative analysis of waste management requirements between five green building rating systems for new residential buildings. J. Clean. Prod. 2016, 112, 895-902. [CrossRef]

170. Cha, H.S.; Kim, J.; Han, J.Y. Identifying and assessing influence factors on improving waste management performance for building construction projects. J. Constr. Eng. Manag. 2009, 135, 647-656. [CrossRef]

171. Wu, S.R.; Apul, D. Framework for integrating indoor air quality impacts into life cycle assessments of buildings and building related products. J. Green Build. 2015, 10, 127-149. [CrossRef]

172. Wang, B.Z.; Zhu, Z.H.; Yang, E.; Chen, Z.; Wang, X.H. Assessment and management of air emissions and environmental impacts from the construction industry. J. Environ. Plan. Manag. 2018, 61, 2421-2444. [CrossRef]

173. Hu, M.; Van Der Voet, E.; Huppes, G. Dynamic material flow analysis for strategic construction and demolition waste management in Beijing. J. Ind. Ecol. 2010, 14, 440-456. [CrossRef]

174. Pan, X.; Xie, Q.; Feng, Y. Designing recycling networks for construction and demolition waste based on reserve logistics research field. J. Clean. Prod. 2020, 260, 120841. [CrossRef]

175. Jain, S.; Singhal, S.; Pandey, S. Environmental life cycle assessment of construction and demolition waste recycling: A case of urban India. Resour. Conserv. Recycl. 2020, 155, 104642. [CrossRef]

176. Lawson, N.; Douglas, I.; Garvin, S.; McGrath, C.; Manning, D.; Vetterlein, J. Recycling construction and demolition wastes-A UK perspective. Environ. Manag. Health 2001, 12, 146-157. [CrossRef]

177. Kallio, H.; Pietilä, A.M.; Johnson, M.; Kangasniemi, M. Systematic methodological review: Developing a framework for a qualitative semi-structured interview guide. J. Adv. Nurs. 2016, 72, 2954-2965. [CrossRef]

178. Glossary: Chain Index. 2013. Available online: https:/ /ec.europa.eu/eurostat/statistics-explained/index.php?title=Glossary: Chain_inde (accessed on 24 September 2021). 
179. Li, Y.N.; Cai, M.; Wu, K.; Wei, J. Decoupling analysis of carbon emission from construction land in Shanghai. J. Clean. Prod. 2019, 210, 25-34. [CrossRef]

180. IPCC. Summary for Policymakers. Climate Change 2021: The Physical Science Basis. Contribution of Working Group I to the Sixth Assessment Report of the Intergovernmental Panel on Climate Change. 2021. Available online: https://www.ipcc.ch/report/ar6/wg1 /downloads/report/IPCC_AR6_WGI_Full_Report.pdf (accessed on 19 September 2021).

181. PRB. Population Mid-2020 (Millions). 2020. Available online: https://www.prb.org/international/indicator/population/table/ (accessed on 21 September 2021).

182. UNFCC. India's Intended Nationally Determined Contribution: Working towards Climate Justice. 2015. Available online: https:// www4.unfccc.int/sites/ndcstaging/PublishedDocuments/India\%20First/INDIA\%20INDC\%20TO\%20UNFCCC.pdf (accessed on 24 September 2021). 